May 1999 • NREL/SR-540-26003

\title{
Texas Bi-Fuel Liquefied Petroleum Gas Pickup Study: Final Report
}

Y. Huang, R.D. Matthews, and E.T. Popova The University of Texas at Austin Austin, Texas

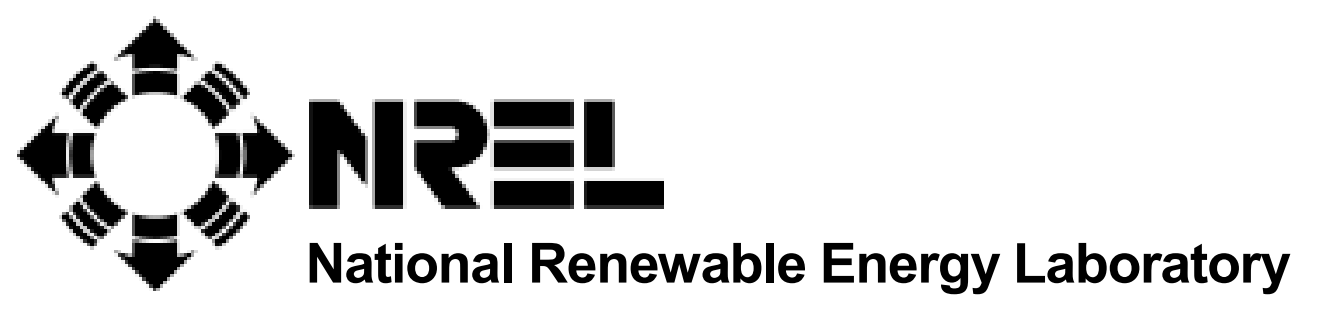

1617 Cole Boulevard Golden, Colorado 80401-3393

NREL is a U.S. Department of Energy Laboratory Operated by Midwest Research Institute $\bullet$ Battelle $\bullet$ Bechtel Contract No. DE-AC36-98-G010337 
May 1999 • NREL/SR-540-26003

\title{
Texas Bi-Fuel Liquefied Petroleum Gas Pickup Study: Final Report
}

\author{
Y. Huang, R.D. Matthews, and E.T. Popova \\ The University of Texas at Austin \\ Austin, Texas
}

NREL Technical Monitor: P. Whalen

Prepared under Subcontract No. XCI-7-17004-01

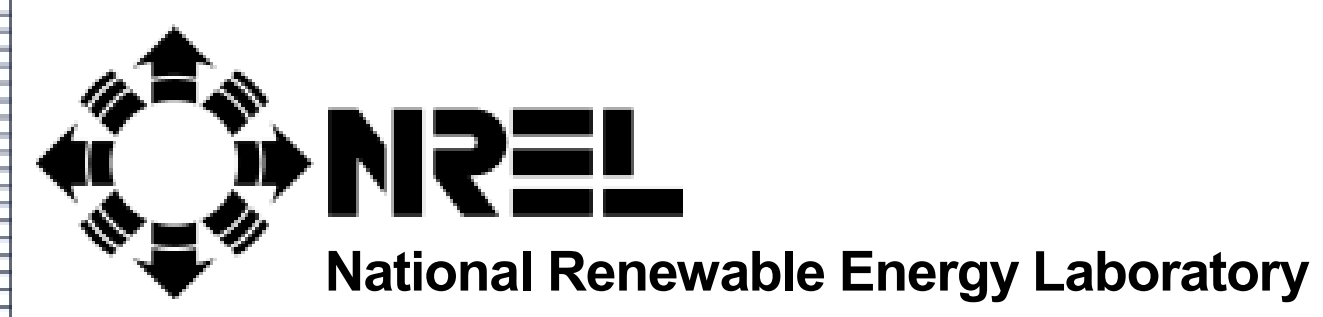

1617 Cole Boulevard

Golden, Colorado 80401-3393

NREL is a U.S. Department of Energy Laboratory

Operated by Midwest Research Institute $\bullet$ Battelle $\bullet$ Bechtel

Contract No. DE-AC36-98-G010337 


\section{NOTICE}

This report was prepared as an account of work sponsored by an agency of the United States government. Neither the United States government nor any agency thereof, nor any of their employees, makes any warranty, express or implied, or assumes any legal liability or responsibility for the accuracy, completeness, or usefulness of any information, apparatus, product, or process disclosed, or represents that its use would not infringe privately owned rights. Reference herein to any specific commercial product, process, or service by trade name, trademark, manufacturer, or otherwise does not necessarily constitute or imply its endorsement, recommendation, or favoring by the United States government or any agency thereof. The views and opinions of authors expressed herein do not necessarily state or reflect those of the United States government or any agency thereof.

Available to DOE and DOE contractors from:

Office of Scientific and Technical Information (OSTI)

P.O. Box 62

Oak Ridge, TN 37831

Prices available by calling 423-576-8401

Available to the public from:

National Technical Information Service (NTIS)

U.S. Department of Commerce

5285 Port Royal Road

Springfield, VA 22161

$703-605-6000$ or $800-553-6847$

or

DOE Information Bridge

http://www.doe.gov/bridge/home.html

Printed on paper containing at least $50 \%$ wastepaper, including $20 \%$ postconsumer waste 


\section{Contents}

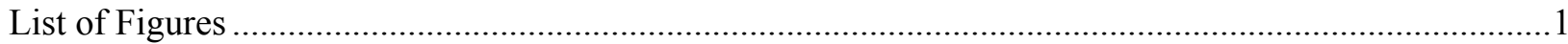

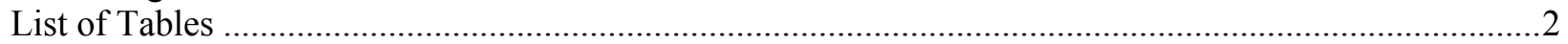

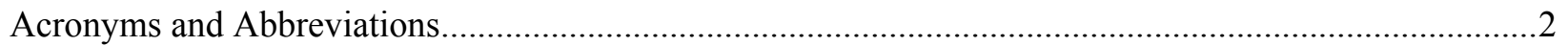

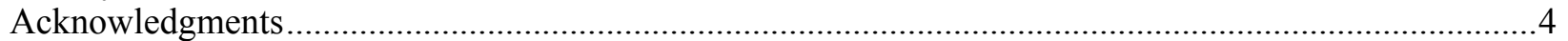

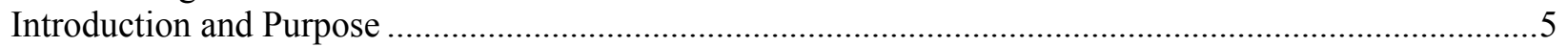

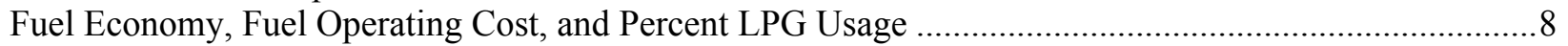

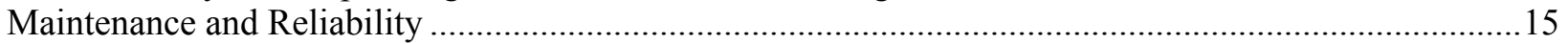

Summary of Operating Costs for Identical Gasoline and Bi-Fuel Vehicles..........................................20

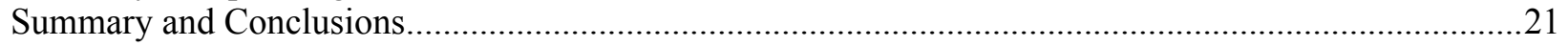

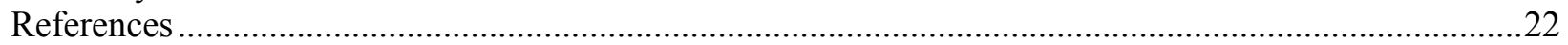

Appendix A: Monthly Data Regarding Fuel Use.......................................................................... A-1

Appendix B: Methods for Determining Combined Fuel Economy and Fuel Operating Cost.................. B-1

Appendix C: Discussion of Statistics Related to Fuel Use .................................................................

Appendix D: Detailed Maintenance and Repair Data and Cost Summaries ..................................... D-1

Appendix E: Statistics for Scheduled and Unscheduled Maintenance and Reliability .......................... E-1

\section{List of Figures}

Figure 1. Locations of the district headquarters for the project vehicles: 17 in Corpus Christi, 17 in Houston, and 1 in Austin

Figure 2. One of the F150 trucks used for the project (photo courtesy of TxDOT) ............................... 7

Figure 3. Fuel economy in miles per actual gallon as a function of percent LPG used for the vehicles that averaged $12.7 \mathrm{mpegg} \pm 6 \%$ (Circles on the plot represent selected fuel economy data.) .................11

Figure 4. Monthly purchase prices of gasoline and LPG (Note: the price of LPG was higher in the Corpus district than in the Houston district.) …............................................................................ 13

Figure 5. Fuel operating cost versus percent LPG usage. Data are shown for vehicles that averaged 12.7 mpegg $\pm 6 \%$. Notes: Houston $=$ circles, Corpus $=$; solid lines are theoretical relationships for vehicles that achieve precisely $12.7 \mathrm{mpegg}$; dashed lines are for vehicles with $6 \%$ lower fuel economy (11.94 mpegg) via Equations $5 \mathrm{a}$ and $5 \mathrm{~b}$; and dotted lines are for vehicles with $6 \%$ higher fuel economy (13.46 mpegg) via Equations 5a and 5b...............................................................14

Figure 6. Texas' annual alternative fuel tax, expressed on a per-mile basis ...........................................15

Figure 7. Total number of repairs versus total miles accumulated over the project period. Each vehicle, except the gasoline-only vehicles, has two data points at its final mileage at the end of the project: a circle for the number of LPG system repairs and a square for the number of non-LPG-related repairs.

Figure 8. Comparisons of the repair rates for the study vehicles 19 


\section{List of Tables}

Table 1. Vehicle Descriptions: LPG and Gasoline Ford F150 Pickup Trucks ...

Table 2. Fuel Economy for Trucks Operating Exclusively on Either LPG or Gasoline over an Extended Period

Table 3. Mean Costs for Scheduled Maintenance ( $\$ /$ mile)

Table 4. Summary of Costs for Bi-Fuel and Gasoline-Only Vehicles (cents/mile) ......

\section{Acronyms and Abbreviations}

AFV

ALVW

CFE

$\mathrm{CFE}^{\prime}$

CIFE

CIFE'

$\mathrm{DB}$

FE

FOC

FOC'

FTP

GVWR

IGU

IGU'

IMD

IMD'

IPU

IPU'

LDT3

LDV

LPG

mpg

mpegg

QVM

SGC'

SPC

TGC

TGC'

TGU

TGU'

TMD alternative fuel vehicle

adjusted loaded vehicle weight ([curb weight + GVWR]/2)

combined (gasoline plus LPG) fuel economy in mpegg, from log form data

combined (gasoline plus LPG) fuel economy in mpegg, from TxDOT database records

combined incremental fuel economy in mpegg, from log form data

combined incremental fuel economy in mpegg, from TxDOT database records

TxDOT database download

fuel economy, in mpg or mpegg

fuel operating cost, in cents/mile, from log form data

fuel operating cost, in cents/mile, from TxDOT database records

Federal Test Procedure driving cycle; used for emissions certification and determination of urban fuel economy

gross vehicle weight rating

gasoline gallons added in a given month, from log form data

gasoline gallons added in a given month, from TxDOT database records

miles driven in a given month, from log form data

miles driven in a given month, from TxDOT database records

LPG gallons added in a given month, from log form data

LPG gallons added in a given month, from TxDOT database records

light duty truck (LDV with $3751 \leq \mathrm{ALVW}<5750 \mathrm{lb}$ )

light duty vehicle $($ GVWR $<8500 \mathrm{lb})$

liquefied petroleum gas

miles per actual gallon

miles per equivalent gallon of gasoline

Qualified Vehicle Modifier, a Ford program for approved alternative fuel conversions the gasoline purchase price paid by TxDOT

the actual LPG purchase price (\$/LPG gallon)

cumulative cost for the total gallons of gasoline consumed over the project period, from $\log$ form data for TGU

cumulative cost for the total gallons of gasoline consumed over the project period, from TxDOT database records for TGU'

cumulative total gallons of gasoline used over the period of the project, from log form data

cumulative total gallons of gasoline used over the period of the project, from TxDOT database records

cumulative total miles driven, from log form data 


\section{Acronyms and Abbreviations (concluded)}

TMD' cumulative total miles driven, from TxDOT database records

TPC cumulative cost for the total gallons of LPG consumed over the project period, using log form data for TPU

$\mathrm{TPC}^{\prime}$ cumulative cost for the total gallons of LPG consumed over the project period, using TxDOT database records for TPU'

TPU cumulative total gallons of LPG used over the period of the project (in actual LPG gallons), from log form data

TPU' cumulative total gallons of LPG used over the period of the project (in actual LPG gallons), from TxDOT database records

TxDOT Texas Department of Transportation

US06 a high speed, hard acceleration driving cycle; used for part of the Supplemental FTP

UT The University of Texas

VOLF vehicle operation log form 


\section{Acknowledgments}

The Office of Technology Utilization in the U.S. Department of Energy's Office of Transportation Technologies was the primary funding source for this project. In addition, we extend our appreciation to Don Lewis, Keith Davis, and Frank Nieto of the Texas Department of Transportation (TxDOT) General Services Division Alternative Fuels Group and Kirby Moore, TxDOT equipment operations systems administrator, for their support. Within the Corpus Christi district, we are grateful for the aid and patience of: Johnny Martinez, equipment supervisor; Bob Blackwell, director of maintenance; Jack Jenkins, maintenance supervisor of the George West Section; Laura Ashcraft; Cristoval Gonzales; and Becky Kureska. Within the Houston district, we appreciate the aid and patience of: Lenert Kurtz, equipment supervisor; Steve Simmons, deputy district engineer; Janelle Gbur, public information officer; Juan Rodriguez, preventive maintenance coordinator; Sharla Bridges, administrative technician; Jesus Garcia, Ft. Bend Area engineer; and Carol Huser. Our gratitude is also extended to the local section supervisors and drivers for their cooperation on this project. Peg Whalen of the National Renewable Energy Laboratory is thanked for her aid and guidance on this project. The findings and opinions expressed herein are those of the authors and do not necessarily reflect the views of the sponsors or participants. 


\section{Introduction and Purpose}

Alternative fuels may be an effective means for decreasing America's dependence on imported oil; creating new jobs; and reducing emissions of greenhouse gases, exhaust toxics, and ozone-forming hydrocarbons (see, for example, Wu et al., 1998a). The cost effectiveness of alternative fuel vehicles has been examined in several studies (Wang et al., 1993; Herridge and Lambert, 1995; Dardalis et al., 1998). However, data regarding in-use fuel economy and especially maintenance characteristics of alternative fuel vehicles (AFVs) have been limited in availability.

In Texas, one of the most widely used alternative fuels is liquefied petroleum gas (LPG, often referred to as propane). The largest fleet in Texas, operated by the Texas Department of Transportation (TxDOT), has hundreds of bi-fuel (LPG and gasoline) vehicles operating in normal daily service.

This study was undertaken to compare the operating and maintenance characteristics of bi-fuel vehicles (which use LPG as the primary fuel) to those of nominally identical gasoline vehicles. The project was funded by the U.S. Department of Energy (DOE) and managed by DOE's National Renewable Energy Laboratory (NREL).

The project was conducted over a 2-year period, including 18 months (April 1997-September 1998) of data collection on operations, maintenance, and fuel consumption of the vehicles under study. This report summarizes the project and its results.

\section{Project Participants}

This project required the cooperation of several participants. Investigators at the University of Texas (UT) conducted the project with technical direction from NREL. TxDOT agreed to participate and allowed the university to collect detailed data on the study vehicles. The General Services Division at TxDOT headquarters in Austin coordinated the data collection efforts between two of its districts and UT, and provided printouts of the computer-based vehicle records that were essential to this project. The two TxDOT districts that took part in the project are located in Houston and Corpus Christi. These two district offices provided fuel addition data and maintenance data for the research vehicles located within their respective districts, and provided access for UT research personnel to acquire other necessary information from their hard copy records.

An initial coordinating meeting was held in Austin, including representatives from TxDOT, UT, and NREL. Two kickoff meetings were held at the district sites, in Houston and Corpus Christi, shortly before data collection began

\section{The Study Fleet}

The project fleet consisted of 351996 Ford F150 half-ton pickup trucks with 4.9-L inline six-cylinder engines. Among them, 31 pickups were bi-fueled (15 in the TxDOT Houston district and 16 in the TxDOT Corpus Christi district) and 4 were gasoline-only counterparts used as control vehicles ( 2 in the TxDOT Houston district, 1 in the Corpus Christi district, and 1 located at UT). Figure 1 shows these locations. 


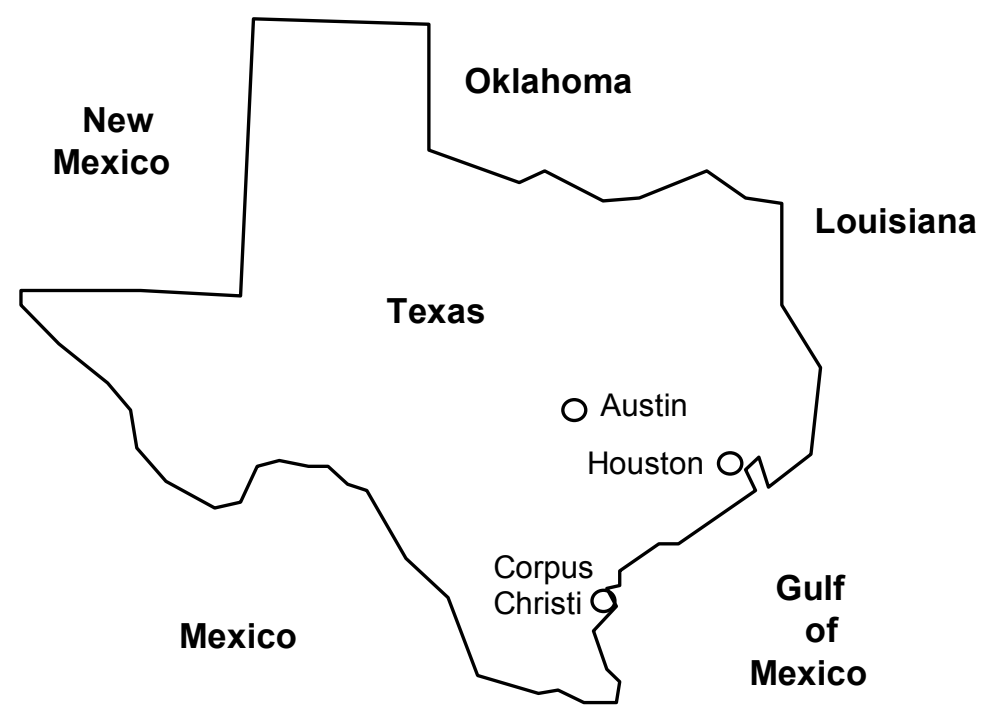

Figure 1. Locations of the district headquarters for the project vehicles: 17 in Corpus Christi, 17 in Houston, and 1 in Austin

TxDOT uses these types of vehicles to transport personnel and light equipment for road design and maintenance, right-of-way acquisition, construction oversight, and transportation planning of state roadways.

The Houston district covers 5,948 square miles, and includes 8,725 lane miles on which 3,262,598 registered vehicles travel 56,158,687 miles daily. TxDOT operates approximately 450 AFVs within its Houston district. The Corpus Christi district, which covers 7,806 square miles and includes 6,796 lane miles on which 394,849 registered vehicles travel 10,140,215 miles daily, operates approximately 131 AFVs.

The 31 bi-fuel research vehicles were Ford F150 pickups converted to LPG using Impco Technologies' mixer systems via Ford's Qualified Vehicle Modifier (QVM) Program (see Figure 2). Table 1 presents the characteristics and specifications of both the bi-fuel and gasoline-only research vehicles.

\section{Data Collection and Evaluation}

Three types of data were collected: fuel addition data from vehicle operation log forms; maintenance information collected by UT research personnel from the TxDOT districts and local Ford dealerships that performed warranty maintenance; and records from TxDOT's mainframe computer (fuel addition and maintenance).

Fuel addition data were collected from each driver of each study vehicle. The 34 TxDOT drivers who took part in this project voluntarily filled out a vehicle operation log form designed by UT and TxDOT 


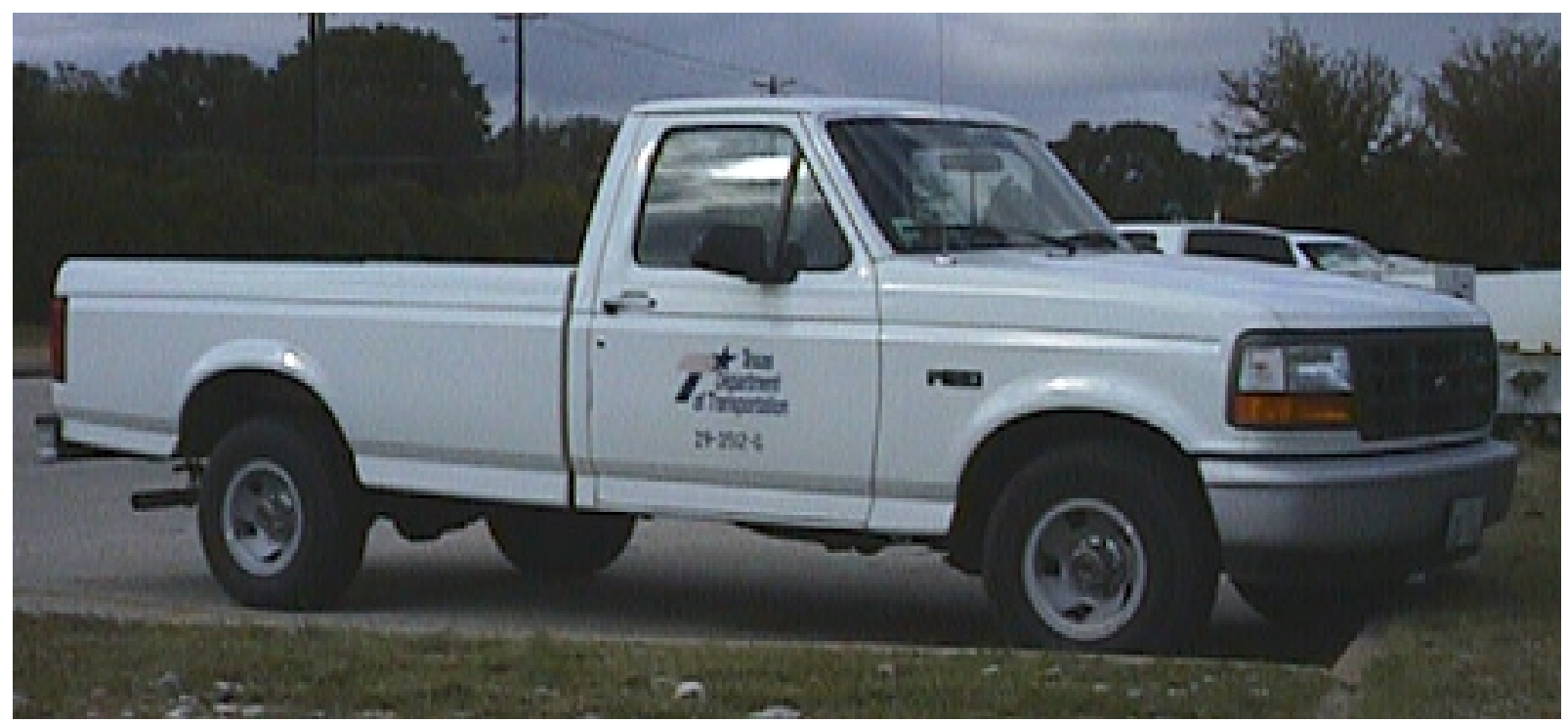

Figure 2. One of the F150 trucks used for the project (photo courtesy of TxDOT)

Table 1. Vehicle Descriptions: LPG and Gasoline Ford F150 Pickup Trucks

\begin{tabular}{|c|c|c|}
\hline & LPG/Gasoline & Gasoline Only \\
\hline Make & Ford & Ford \\
\hline Model Code & F150 & F150 \\
\hline Body Style & $1 / 2$ ton pickup & $1 / 2$ ton pickup \\
\hline Model Year & 1996 & 1996 \\
\hline Model Class & LDV/LDT3 & LDV/LDT3 \\
\hline Air Conditioning & Yes & Yes \\
\hline Fuel System & Bi-fuel & Dedicated \\
\hline Fuel Tank Capacity (gal) & 48 LPG (at $80 \%$ full) +18.2 & 2 tanks: \\
& gasoline & $19+18.2$ \\
\hline Fuel System Material & Steel & Steel \\
\hline GVWR (lb) & 6,250 & 6,000 \\
\hline Engine Model Number & 4.9 LI6 & 4.9 LI6 \\
\hline Engine & 4.9L in-line 6 cylinder & 4.9L in-line 6 cylinder \\
\hline Turbocharged & No & No \\
\hline Engine Horsepower & 145 & 145 \\
\hline Transmission Type & 4-speed automatic & 4-speed automatic \\
\hline Wheel Drive & Rear & Rear \\
\hline
\end{tabular}

for this project. They had no other obligations to the project. The compliance rate for filling out these forms was quite good except for a few of the drivers in the Corpus district. The vehicle operation log form includes:

- Date

- Mileage at the beginning of the day

- Mileage at the end of the day

- Mileage at the time of refueling 
- Fuel added (LPG or gasoline)

- Amount of fuel.

The major source of maintenance data was the TxDOT maintenance file records at the local districts. The following data were recorded:

- Repair order open date

- Mileage when the repair order opened (if applicable)

- Cost of maintenance

- Labor hours

- Category of maintenance (scheduled, unscheduled, warranty)

- Type of maintenance performed.

If a warranty repair was indicated by the TxDOT district records, we visited the local Ford dealerships to obtain labor hours and parts costs. Although warranty repairs are generally done at no cost to the vehicle owner, a few of the vehicles accumulated sufficient mileage before the end of the project to exceed the warranty limit. More importantly, we wanted to extrapolate the costs of the bi-fuel vehicles beyond the warranty period, because TxDOT almost always keeps vehicles beyond this period.

Finally, data were also downloaded from TxDOT's mainframe computer on a monthly basis. This included:

- Cumulative fuel usage

- Cumulative oil usage

- Cumulative vehicle downtime

- Cumulative mileage (last odometer reading).

TxDOT also provided fuel purchase price data for both LPG and gasoline. All collected data were entered into a database on a PC, processed by UT investigators, and submitted to NREL each month. The project started on April 1, 1997, but our initial download from the TxDOT database was in June of 1997. To keep the same time basis for the results from the vehicle log forms and from the database records, the analyses include the data beginning in June, except for some of the fuel economy comparisons, as will be discussed later. The statistical analyses included fuel consumption, scheduled maintenance, unscheduled maintenance (repairs), and reliability of the vehicles being studied.

\section{Fuel Economy, Fuel Operating Cost, and Percent LPG Usage}

For LPG and some other alternative fuels, the lower fuel price relative to gasoline represents potential savings to the vehicle or fleet owner. The magnitude of this savings will depend on the relative costs of LPG and gasoline, the percent use of the alternative fuel, and the fuel economy of the vehicle. These factors combine to yield the fuel cost per mile (the fuel operating cost).

During the 18 months of data collection, 2,871 refueling data points were recorded. In addition to the data from the vehicle operation log forms, for each of the vehicles in the project TxDOT provided monthly mileage driven, fuel usage (LPG and gasoline gallons), and oil usage and oil cost records, all downloaded from its database each month. TxDOT also provided the monthly purchase price of each fuel (LPG and gasoline). The refueling data from the log forms are attached as Table A-1 in Appendix A and the corresponding data from the TxDOT database are provided as Table A-2. The results summarized in this section are based on these data. 
Examining Tables A-1 and A-2 reveals that both the monthly mileage driven and fuel usage downloaded from the TxDOT database are different from those we extracted from the vehicle operation log forms. This resulted from the fact that the cutoff dates for the TxDOT data processing are different from the direct data collection. Thus, as discussed in more detail in Appendix B, four methods are available for calculating the fuel economy for each of the vehicles in the project:

- Overall (long-term) analysis from the database records

- Overall (long-term) analysis from the vehicle operation log forms

- Statistical analysis of the data on the vehicle operation log forms

- Statistical analysis from monthly database records.

\section{Fuel Economy}

All the AFVs studied were bi-fueled. The operators of these trucks used both LPG and gasoline and no attempt was made to track the exact mileage when the operators switched from one fuel to the other. The operators can refuel both LPG and gasoline to separate tanks at each refueling. Furthermore, LPG and gasoline have different energy densities (fuel energy per actual gallon). These factors complicate the determination of fuel economy.

We requested that all operators of the bi-fuel vehicles in the project use LPG exclusively for one month and gasoline exclusively for another month, and many complied. These results yield data sets for the fuel economy for LPG-only for the bi-fuel vehicles and for gasoline-only for the bi-fuel vehicles.

The fuel economy was determined as the ratio of the total mileage driven during the period of use of one fuel exclusively to the total actual gallons (i.e., gallons of LPG rather than equivalent gallons of gasoline) of fuel used. All the data used in these calculations were obtained from the vehicle operation log forms. Table 2 presents the results for these vehicles.

As derived in Appendix B, after accounting for the differences in heating values and specific gravities of LPG and gasoline, it can be shown that 1.36 LPG gallons have the same energy content as 1 gallon of gasoline. Based on this, we expect that the fuel economy for operation on LPG should be $73.53 \%$ of that for operation on gasoline, when both are expressed on the basis of actual gallons.

Table 2 reveals that, on average, the bi-fuel vehicles running on LPG only exhibited a fuel economy $75.76 \%$ that of the average for those running on gasoline only when both are expressed in actual gallons rather than equivalent gallons. Within the uncertainty of the data, this agrees with the theoretical value (73.53\%). This result was expected because "The Texas Project" (Matthews et al., 1996; Chiu and Matthews, 1996; Wu et al., 1996, 1998a), showed that, on average, bi-fuel LPG vehicles had the same fuel economy on LPG as when tested on gasoline when both are expressed in miles per equivalent gallon of gasoline (mpegg). In other words, over a wide variety of environmental and vehicle operating conditions, LPG and gasoline yield the same fuel economy in mpegg. Equivalently, the fuel economy when operating on LPG is $73.53 \%$ of that for operation on gasoline, when both are expressed on the basis of actual gallons. 


\section{Table 2. Fuel Economy for Trucks Operating Exclusively on Either LPG or Gasoline over an Extended Period}

\begin{tabular}{|c|c|c|c|c|}
\hline & $\begin{array}{l}\text { Bi-Fuel Vehicle } \\
\text { Equipment } \\
\text { Number }\end{array}$ & $\begin{array}{l}\text { Number of } \\
- \text { Points }\end{array}$ & $\begin{array}{l}\text { Mean (miles } \\
\text { per actual } \\
\text { gallon) }\end{array}$ & $\begin{array}{c}\text { Ratio of MPG(gas) } \\
\text { to MPG (LPG) }\end{array}$ \\
\hline LPG-only & \multirow[t]{2}{*}{ 03649G } & 11 & 9.62 & \multirow[t]{2}{*}{1.34} \\
\hline gasoline-only & & 5 & 12.93 & \\
\hline LPG-only & \multirow[t]{2}{*}{ 03651G } & 2 & 9.67 & \multirow[t]{2}{*}{1.25} \\
\hline gasoline-only & & 8 & 12.09 & \\
\hline LPG-only & \multirow[t]{2}{*}{$03652 \mathrm{G}$} & $\overline{77}$ & 111.32 & \multirow[t]{2}{*}{ 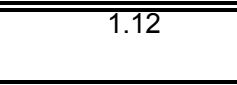 } \\
\hline gasoline-only & & 6 & 12.73 & \\
\hline LPG-only & \multirow[t]{2}{*}{ 05974F } & $\overline{5}$ & 9.51 & \multirow[t]{2}{*}{ 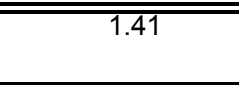 } \\
\hline gasoline-only & & 3 & 13.45 & \\
\hline LPG-only & \multirow[t]{2}{*}{ 05994F } & 12 & 9.91 & \multirow[t]{2}{*}{1.31} \\
\hline gasoline-only & & 10 & 12.95 & \\
\hline "LPG-only & \multirow[t]{2}{*}{ 05995F } & $\overline{5}$ & 8.00 & \multirow[t]{2}{*}{1.50} \\
\hline gasoline-only & & 1 & 12.03 & \\
\hline LPG-only & \multirow[t]{2}{*}{ 05996F } & $\overline{15}$ & 9.22 & \multirow[t]{2}{*}{1.29} \\
\hline gasoline-only & & 9 & 11.88 & \\
\hline \multicolumn{4}{|l|}{ Average ratio } & 1.32 \\
\hline
\end{tabular}

Because of this agreement between the theoretical value and both previous and current experimental data, the combined (overall LPG and gasoline use) fuel economy for the bi-fuel vehicles was calculated using the equivalence:

\subsection{LPG gallons $=1.0$ gasoline gallon}

Four methods for calculating the fuel economy from the recorded data are discussed in Appendix B. Appendix $\mathrm{C}$ summarizes the statistical analysis. As expected, the four different methods for calculating the fuel economy do not yield results that are statistically different at the $95 \%$ confidence level. Specifically, all yield a fuel economy for combined operation on both LPG and gasoline of $\sim 12.7 \mathrm{mpegg}$. Furthermore, the fuel economy for the gasoline-only vehicles cannot be said (with at least $95 \%$ confidence) to be statistically different from that for the bi-fuel vehicles. This is much less than the EPA-rated highway and urban fuel economy of these vehicles, $18 \mathrm{miles} /$ gallon and $14 \mathrm{miles} /$ gallon, respectively, illustrating the importance of the duty cycle on the fuel economy. The results in Table 2 also illustrate the dependence of the fuel economy on the duty cycle: during gasoline-only operation one vehicle obtained $11.88 \mathrm{mpg}$; another had a fuel economy of $13.45 \mathrm{mpg}$ ( $14 \%$ higher). This dependence of the fuel economy on the duty cycle is also evident for the bi-fuel vehicles. For example, in Appendix A, the vehicle with the worst combined fuel economy over the project period averaged $9.92 \mathrm{mpegg}$. Another that used LPG essentially as often averaged $13.87 \mathrm{mpegg}$ (40\% higher).

Because of the different energy contents of LPG and gasoline, the fuel economy in miles per actual gallon depends on the percent use of LPG. A vehicle that has a fuel economy of 12.7 mpegg will achieve 12.7 miles per actual gallon when operating exclusively on gasoline and 9.3 miles per actual gallon when operating exclusively on LPG. For bi-fuel vehicles, the relationship between miles per actual gallon and percent use of LPG is illustrated in Figure 3. Data extracted from the database records (Table A-2) for those vehicles achieving a combined fuel economy of $12.7 \mathrm{mpegg} \pm 6 \%$ is also shown in Figure 3 for comparison. As expected, the agreement between the data and the theory is quite good. 


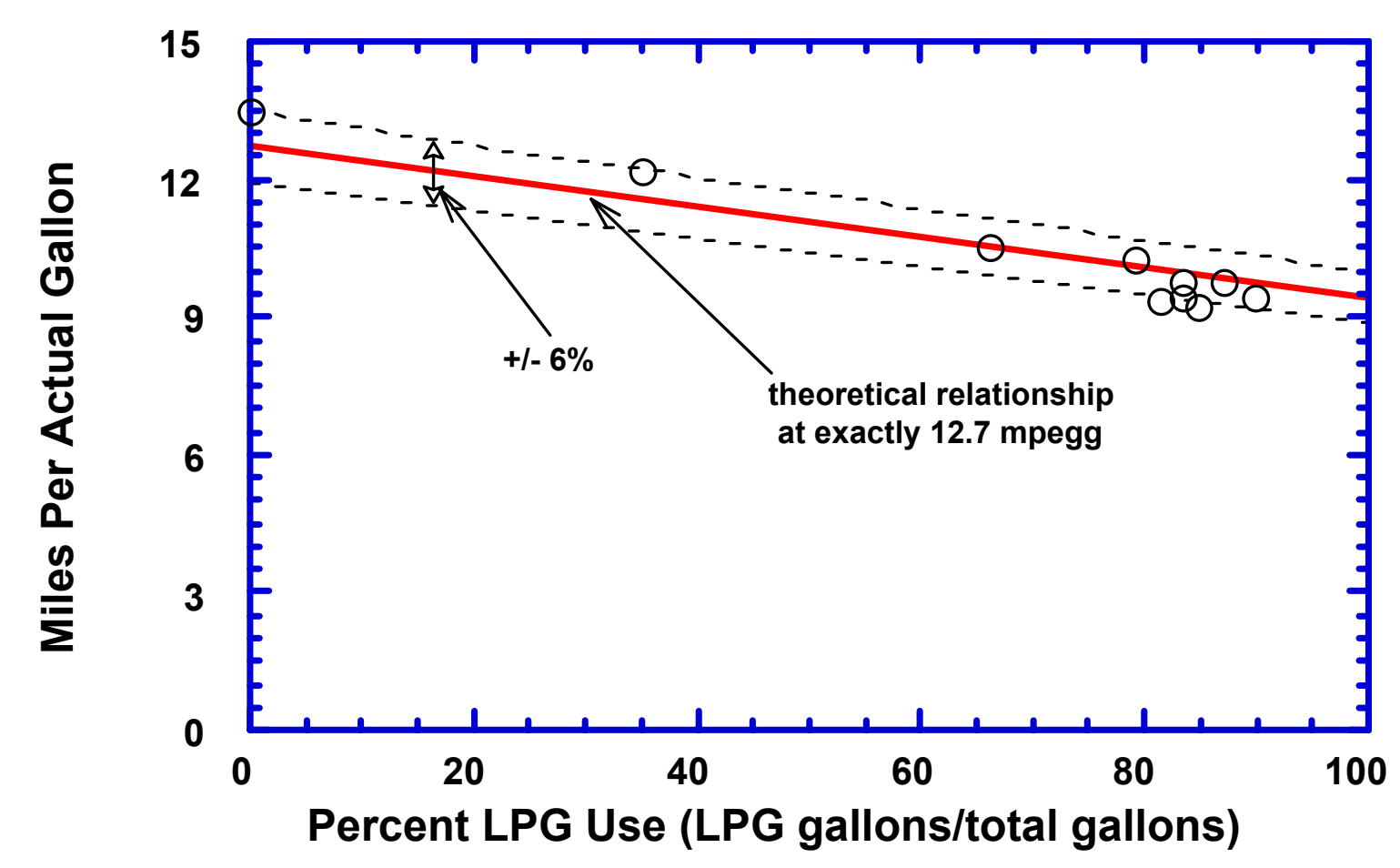

Figure 3. Fuel economy in miles per actual gallon as a function of percent LPG used for the vehicles that averaged $12.7 \mathrm{mpegg} \pm 6 \%$

(Circles on the plot represent selected fuel economy data.)

\section{Percent Use of LPG}

The same data sets used to determine the fuel economy were used to examine the percent use of LPG:

$\% \mathrm{LPG}=100 * \mathrm{TPU} /(\mathrm{TPU}+\mathrm{TGU})$

where TPU is the total gallons of LPG used over the period of the project (in actual LPG gallons) and TGU is the total gallons of gasoline, for each individual vehicle. Data from both the vehicle operation $\log$ forms and from the TxDOT database were used to calculate the percent use of LPG, and Appendix C summarizes the statistical results. As expected, the two data sets yield a value that cannot be said to be statistically different with at least $95 \%$ confidence. Specifically, the bi-fuel vehicles in the study fleet averaged $\sim 78 \%$ use of LPG.

\section{Fuel Operating Cost}

The fuel operating cost depends on the fuel economy and the percent use of LPG, both of which were discussed above. Additionally, the fuel operating cost depends on the purchase price of the fuel. Fuel prices are discussed below, followed by results for the fuel operating cost.

The fuel price depends on the type of fleet. State-owned fleets do not pay federal taxes on gasoline, but private fleets do pay federal taxes (at the pump). In Texas, both private vehicles and state fleet vehicles pay a state tax on gasoline at the pump and both pay a state tax on LPG via an annual tax on AFVs. This annual tax is discussed in a later section. 
A discount on LPG can be obtained via a large bulk purchase, and large private fleets and state fleets can realize this savings. The Corpus Christi district has not installed an on-site LPG refueling facility, but the Houston district does have an LPG refueling facility on site. However, TxDOT pays about the same as for off-site refueling because even for off-site purchases, TxDOT has a contract for LPG that is the sum of a fixed cost plus an increment for the fluctuating market price (and the market price changes weekly). In both the Houston and Corpus districts, fleets are fueled with gasoline both on and off site. The off-site contract for gasoline is similar to that for LPG (i.e., bulk purchase discount), except that the market price increment does not fluctuate as much. According to the Texas Railroad Commission, the average price of LPG available to the general public in absence of a bulk discount is typically $\$ 0.81$ per LPG gallon ( $\$ 1.10$ per equivalent gallon). In comparison, the maximum that either of these two TxDOT districts paid for LPG during this project was approximately 70.6£ per LPG gallon.

Figure 4 illustrates the monthly variations, resulting from the fluctuating market price, in the prices TxDOT paid for gasoline and LPG during this project. The contract that the Corpus district has with its LPG vendors results in a $12.23 \notin$ per LPG gallon higher LPG price than paid in the Houston district. As discussed in Appendix C, the average price paid by TxDOT, for the duration of this project, was $79.79 \notin$ gallon for gasoline, $61.75 \notin$ per LPG gallon in the Corpus district, and $49.52 \phi$ per LPG gallon in the Houston district. The $79.79 \mathrm{\phi} / \mathrm{gallon}$ average for gasoline reflects both the discount for bulk purchase and the fact that state agencies do not pay the federal tax on gasoline. Here, it should again be noted that the gasoline price includes state tax paid at the pump whereas the LPG price does not. Instead, the state "road tax" for LPG is paid via an annual tax on the alternative fuels.

The fuel operating cost (FOC) for each vehicle was determined using the equation:

$\mathrm{FOC}[\$ / \mathrm{mile}]=(\mathrm{TPC}+\mathrm{TGC}) / \mathrm{TMD}$

where TPC and TGC are the costs for the total gallons of LPG and gasoline consumed, respectively, and TMD is the total miles driven.

Appendix $\mathrm{C}$ presents the results from the statistical analyses of the data. As expected, the two sets of data for the bi-fuel vehicles in each district yield results that are not statistically different with at least $95 \%$ confidence. This is also true for the results from the two sets of data for the gasoline-only vehicles. Somewhat surprisingly, the statistical analyses discussed in Appendix $\mathrm{C}$ also indicate that the fuel operating cost is not statistically different, with at least $95 \%$ confidence, between the gasoline-only and bi-fuel vehicles. This results from several factors. First, the number of vehicles is small, especially for the gasoline-only vehicles, and this yields a significant uncertainty in the value of the true mean. Furthermore, the fuel operating cost is a function of the duty cycle, the percent use of LPG, and the relative prices of LPG and gasoline. These factors combine to produce very broad distributions in the data.

As noted above, although the fuel operating cost was calculated using Equation 3 solely from the total LPG and gasoline costs over the miles accumulated during the project, in fact it is a function of the fuel economy (duty cycle), percent use of LPG, and relative prices of LPG and gasoline. This dependence is demonstrated via the following equation:

$$
\begin{gathered}
\text { FOC }(\$ / \mathrm{mi})=\frac{\$ / \mathrm{LPG} \text { gallon }}{\mathrm{FE}_{\mathrm{LPG}}(\mathrm{mi} / \mathrm{LPG} \text { gal })} \cdot \frac{\% \mathrm{LPG}}{100}\left(\frac{\mathrm{LPG} \text { gals }}{\text { total gals }}\right) \\
+\frac{\$ / \text { gasoline gallon }}{\mathrm{FE}_{\text {gas }}(\mathrm{mi} / \text { gasoline gal })} \cdot\left\{1-\frac{\% \mathrm{LPG}}{100}\right\}\left(\frac{\text { gasoline gals }}{\text { total gals }}\right)
\end{gathered}
$$


where $\mathrm{FE}_{\mathrm{LPG}}$ is the fuel economy while operating on LPG in miles per actual LPG gallon, $\mathrm{FE}_{\text {gas }}$ is the fuel economy while operating on gasoline, and \%LPG/100 is the LPG fraction of the total gallons of fuel consumed.

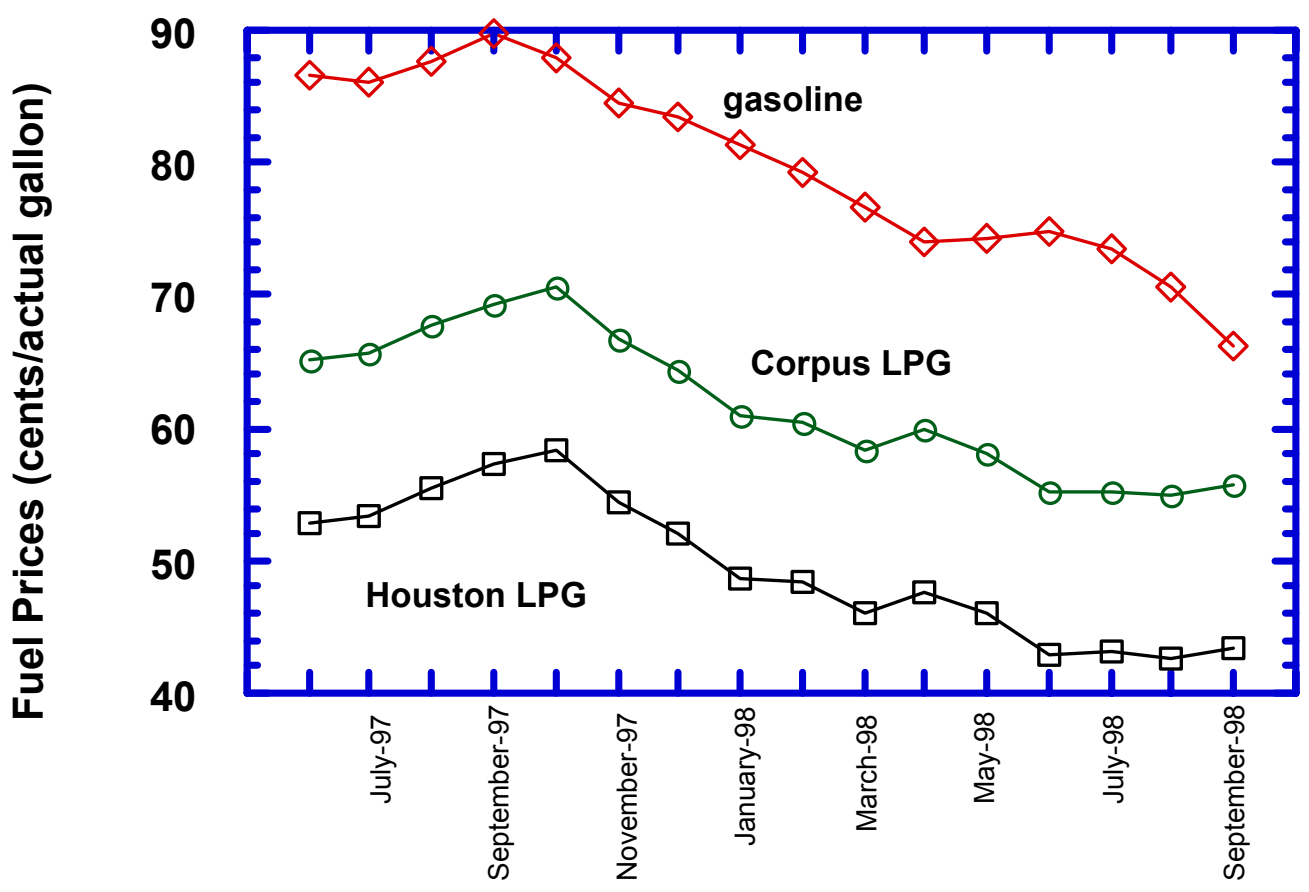

Figure 4. Monthly purchase prices of gasoline and LPG (Note: the price of LPG was higher in the Corpus district than in the Houston district.)

Equation 4 can be used to eliminate many of the variables that produce the broad distributions in the data. In turn, this allows comparison of the gasoline-only and bi-fuel vehicles without these complicating factors. As discussed previously, for this study fleet the fuel economy, on average, is 12.7 mpegg or $12.7 \mathrm{mpg}$ for gasoline and $12.7 / 1.36=9.3$ miles per actual gallon of LPG. The other variables that can be fixed are the average costs of gasoline $(79.79 \phi / \mathrm{gal})$ and LPG $(61.75 \phi$ per actual LPG gallon in the Corpus district; $49.52 \phi$ per actual LPG gallon in the Houston district). Therefore, for a vehicle that averages 12.7 mpegg in the Corpus district, Equation 4 becomes:

$\mathrm{FOC}_{\mathrm{avg}}^{\text {Corpus }}(\$ / \mathrm{mi})=\frac{\$ 0.6175 / \mathrm{LPG} \text { gal }}{9.3 \mathrm{mi} / \mathrm{LPG} \text { gal }} \cdot \frac{\% \mathrm{LPG}}{100}+\frac{\$ 0.7979 / \text { gasol. gal }}{12.7 \mathrm{mi} / \text { gasol. gal }} \cdot\left\{1-\frac{\% \mathrm{LPG}}{100}\right\}$

and for this vehicle in the Houston district:

$$
\operatorname{FOC}_{\text {avg }}^{\text {Houston }}(\$ / \mathrm{mi})=\frac{\$ 0.4952 / \text { LPG gal }}{9.3 \mathrm{mi} / \mathrm{LPG} \text { gal }} \cdot \frac{\% \mathrm{LPG}}{100}+\frac{\$ 0.7979 / \text { gasol. gal }}{12.7 \mathrm{mi} / \text { gasol. gal }} \cdot\left\{1-\frac{\% \mathrm{LPG}}{100}\right\}
$$

The fuel operating cost is shown as a function of percent LPG usage in Figure 5 for the TxDOT vehicles that averaged 12.7 mpegg $\pm 6 \%$ (from the database records). Two aspects of this graph are of note. The first is that Equation 5 predicts the data within $\sim 0.3$ cents/mile, as expected because there are no assumptions in this equation. The second, and most obvious, is that the fuel operating cost increases 
with increasing use of LPG for the Corpus district but decreases with increasing LPG usage for the Houston district. This is because the Corpus district of TxDOT pays more for LPG than for gasoline on an energy content basis $\left(61.75^{*} 1.36=84 \phi\right.$ per energy equivalent gallon for LPG compared to $\sim 80$ cents/gallon for gasoline); the Houston district pays less for LPG than gasoline $(49.52 * 1.36=67 \not$ per energy equivalent gallon for LPG).

The strong effect that the difference in fuel purchase price (the margin or spread) has on the economics of AFVs has been previously reported (Dardalis et al., 1998). The margin between LPG and gasoline for this period of TxDOT operation was in the wrong direction for the Corpus district, with gasoline being the less expensive fuel. The break-even point, when the fuel operating cost is independent of the use of LPG, occurs when the cost per actual LPG gallon equals the cost per gallon of gasoline divided by 1.36. For gasoline at $79.79 \notin$ per gallon, it will cost more to operate on LPG if the cost of LPG is more than $58.67 \notin$ per LPG gallon (as demonstrated in the Corpus district). On the other hand, it will cost less to operate on LPG than gasoline if the LPG can be purchased at less than 58.67 $\not$ per LPG gallon (as was the case for the Houston district). In comparison, the City of San Antonio makes large bulk purchases of LPG to obtain it at $\sim \$ 0.30$ per actual gallon ( $41 \varnothing$ cents per equivalent gallon). For San Antonio's fleet, the slope in Figure 5 would be even more favorable to using LPG than for TxDOT's Houston district.

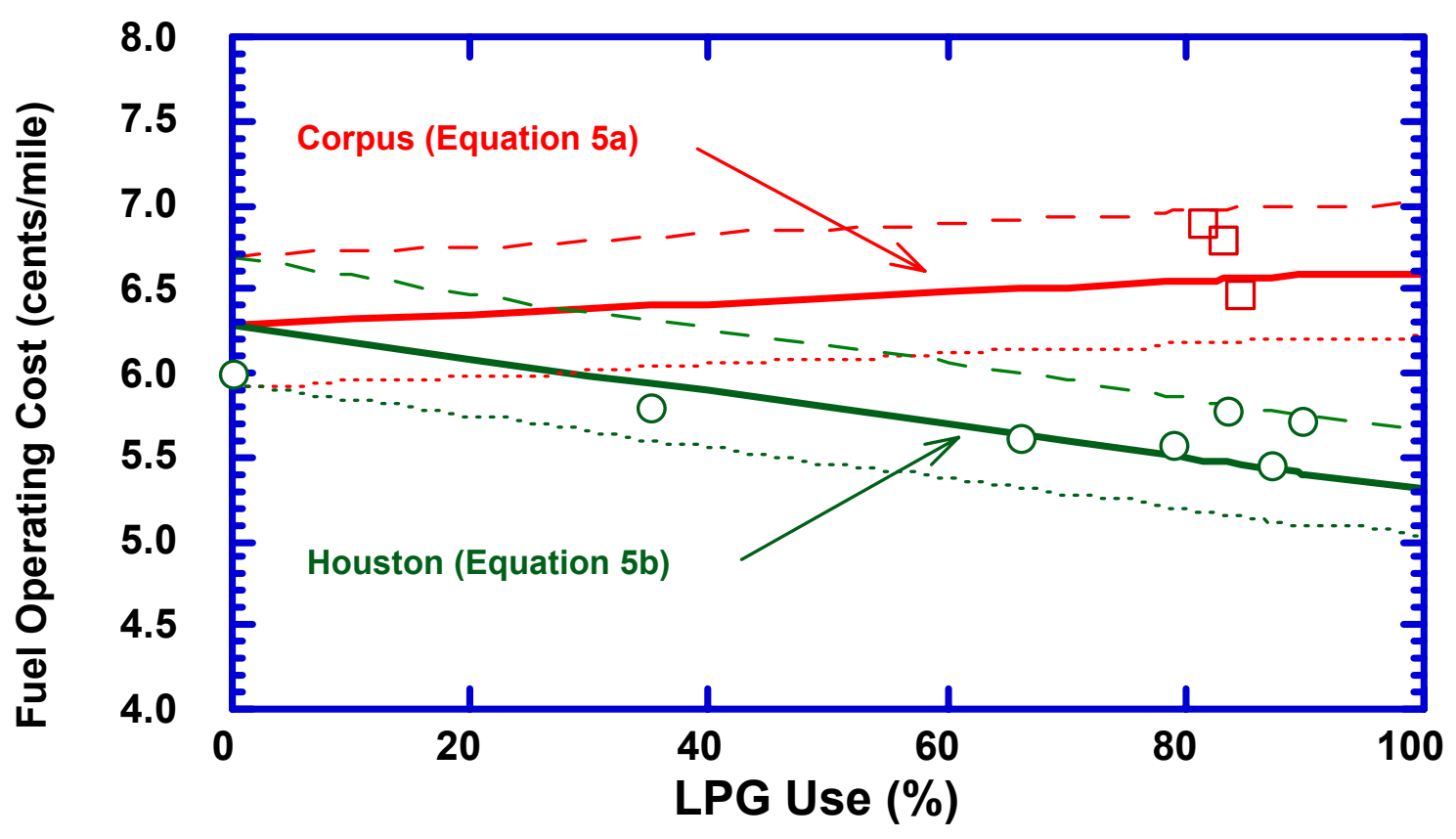

Figure 5. Fuel operating cost versus percent LPG usage. Data are shown for vehicles that averaged $12.7 \mathrm{mpegg} \pm 6 \%$. Notes: Houston $=$ circles,

Corpus $=$ squares; solid lines are theoretical relationships for vehicles that achieve precisely 12.7 mpegg; dashed lines are for vehicles with $6 \%$ lower fuel economy (11.94 mpegg) via Equations $5 a$ and $5 b$; and dotted lines are for vehicles with $6 \%$ higher fuel economy (13.46 mpegg) via Equations $5 \mathrm{a}$ and $5 \mathrm{~b}$. 


\section{Texas' Annual Tax on Alternative Fuels}

As noted above, fleets pay the state tax on LPG indirectly by an annual tax, which depends on the annual mileage accumulation rate and the vehicle weight. For the F150 pickups that are the subject of this study, the annual tax is $\$ 42$ for $<5000$ miles, $\$ 84$ for 5000-9999 miles, $\$ 126$ for 10,000-14,999 miles, and $\$ 168$ for more than 15,000 miles per year. On a per mile basis, this tax is illustrated in Figure 6. The overall TxDOT fleet averages about 15,000 miles per year, at the break point between 0.8 and 1.2 cents per mile. The TxDOT vehicles in the study fleet averaged 17,153 miles per year. If each of the study vehicles averaged 17,153 miles per year, the cost per vehicle for this annual tax would be 0.979 cents per mile. However, because the tax is not a linear function of miles per year (as illustrated in Figure 6), vehicles that accumulate mileage slowly pay a much higher tax in cents per mile. For this reason, the average cost of this annual tax for the study fleet was 1.326 cents per mile. This annual tax on LPG adds to the fuel operating cost for the bi-fuel vehicles independent of whether LPG is used exclusively or not at all.

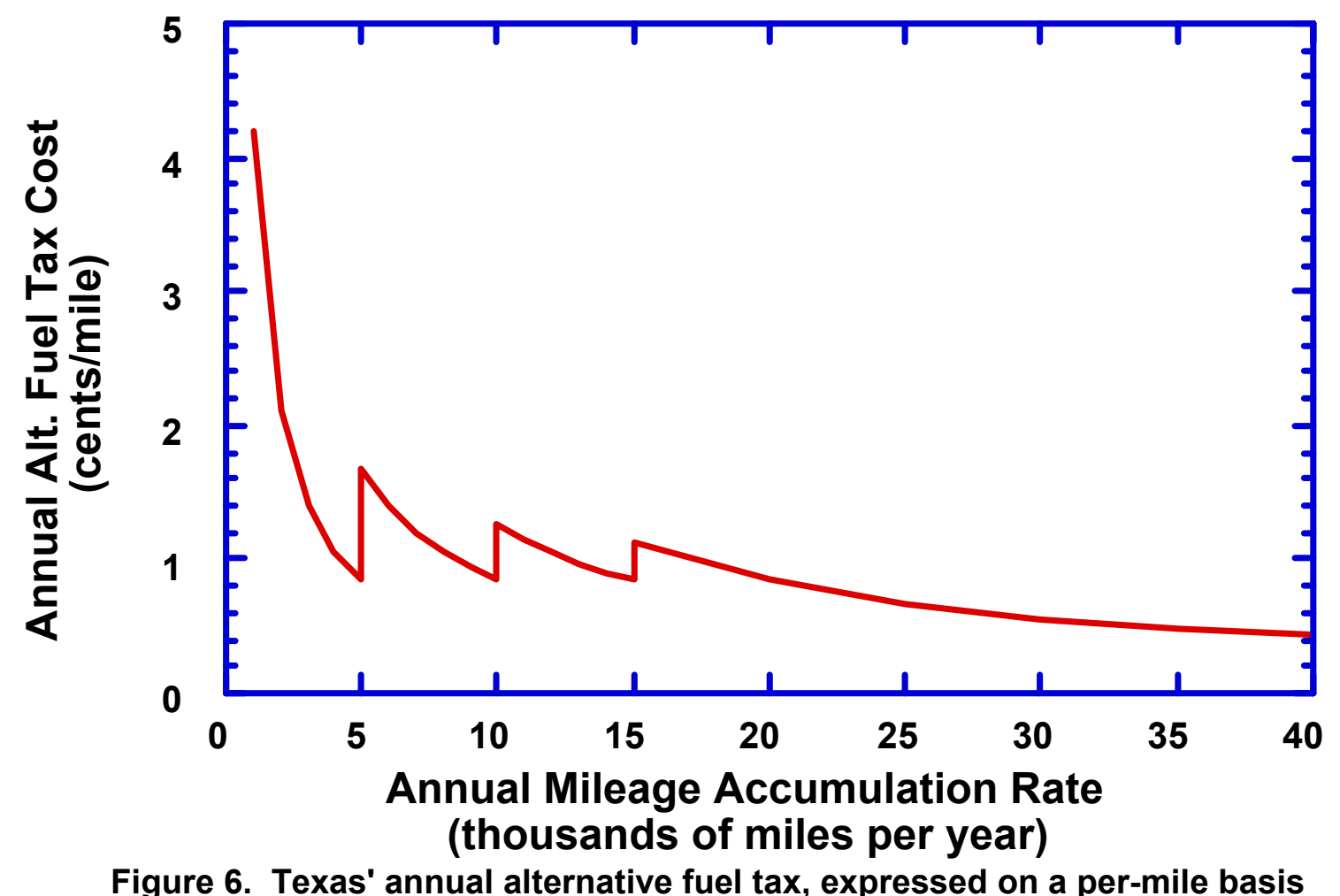

\section{Maintenance and Reliability}

Each month, we visited the Houston and Corpus district sites and their affiliated Ford dealerships (which perform warranty repairs and non-warranty repairs) to collect vehicle maintenance records. These records were used to examine scheduled maintenance, unscheduled maintenance (repairs), and reliability.

For all of the TxDOT vehicles, scheduled maintenance was normally performed by mileage increment, with the exception of oil changes that occurred about every 3 months or 3,000 miles, whichever occurred earlier. Similarly, the number of repairs, and therefore the repair cost, is also expected to be higher for vehicles that accumulated more miles. In other words, the maintenance per vehicle depends on the 
mileage accumulated by that vehicle. For the vehicles in this project, the miles accumulated during the project period varied from a low of 5,676 miles to a high of 56,160 miles. Therefore, the results were analyzed on a cost-per-mile basis.

Appendix D presents the detailed results. Scheduled maintenance, unscheduled maintenance, and reliability are discussed in the following sections.

From the data for each vehicle, as divided into bi-fuel and gasoline-only subgroups, we analyzed the following:

\section{Scheduled Maintenance}

This category included:

- Labor cost for each vehicle in cents/mile

- Parts cost for each vehicle in cents/mile

- Other costs for each vehicle (e.g., used oil disposal) in cents/mile

- Total scheduled maintenance cost for each vehicle in cents/mile.

Scheduled maintenance includes oil changes, oil and air filter replacements, and chassis lubrication. TxDOT performs some of the scheduled maintenance; some is contracted to local vendors. Oil changes are an example of scheduled maintenance that is performed sometimes by TxDOT and sometimes by vendors. Some of the vendors charge a fixed total cost rather than itemizing by parts and labor. In this report, for oil changes performed by such vendors, we apportioned the costs according to the oil change records from the vendors that did itemize.

Additionally, the Houston district uses conventional replacement oil filters whereas the Corpus district uses permanent oil filters that are cleaned rather than replaced. For this reason, the scheduled maintenance data were sorted into bins representing the Corpus and Houston district vehicles separately.

Appendix E presents the summary statistics for scheduled maintenance. Table 3 shows the means and standard deviations (the uncertainty is relatively large, as noted from the standard deviations). Because all the TxDOT vehicles perform scheduled maintenance on the suggested "harsh service" rate of, nominally, every 3 months or 3,000 miles, the scheduled maintenance costs are expected to be the same for the bi-fuel and gasoline-only vehicles. As expected, the mean scheduled maintenance cost per mile for the gasoline-only vehicles is not statistically different (with at least $95 \%$ confidence) from that for the bi-fuel vehicles in the Houston district. Specifically, the mean total (parts plus labor plus "other") cost for scheduled maintenance is $\sim 65$ cents/mile for the gasoline-only vehicles and for the bi-fuel vehicles in the Houston district. However, because permanent oil filters are used in the Corpus district, the cost of parts for scheduled maintenance is $\sim 38 \%$ lower, but the labor cost is $132 \%$ higher for scheduled maintenance in the Corpus district than the Houston district. In other words, the use of permanent oil filters in the Corpus district increases the total cost for scheduled maintenance from $\sim 65$ cents/mile to 82 cents/mile. 
Table 3. Mean Costs for Scheduled Maintenance (\$/mile)

\begin{tabular}{|l|c|c|c|}
\cline { 2 - 4 } \multicolumn{1}{c|}{} & \multicolumn{2}{c|}{ Bi-Fuel } & Gasoline-Only \\
\cline { 2 - 4 } \multicolumn{1}{c|}{} & Corpus & Houston & All \\
\hline Number of Vehicles & 16 & 15 & 0.33 \\
\hline Parts Costs & 0.20 & 0.32 & 0.29 \\
\hline Labor Costs & 0.58 & 0.25 & 0.05 \\
\hline Other Costs & 0.04 & 0.06 & $\mathbf{0 . 6 7}$ \\
\hline Total Costs & $\mathbf{0 . 8 2}$ & $\mathbf{0 . 6 3}$ & 0.16 \\
\hline Standard Deviation of & & & \\
Total Costs & 0.21 & 0.13 & \\
\hline
\end{tabular}

\section{Unscheduled Maintenance}

This category comprised:

- Unscheduled maintenance operating cost for each vehicle in cents/mile

- $\quad$ LPG-related maintenance operating cost for each vehicle in cents/mile

- Non-LPG-related maintenance operating cost for each vehicle in cents/mile

- Total maintenance operating cost for each vehicle in cents/mile.

\section{Projected Repair Costs after the Warranty Period}

The warranty period for these vehicles is 3 years or 36,000 miles, whichever comes first. All but three of the study vehicles were under warranty throughout the project. Therefore, virtually all the repairs were performed at no cost to TxDOT. However, TxDOT generally keeps its vehicles until well after 36,000 miles. Therefore, it was of interest to try to project the repair costs that might be expected after the expiration of the warranty. This section covers the method of projecting these costs, and the results of this analysis.

In general, repairs were performed at the local Ford dealerships. Because all these vehicles were under warranty until near the end of the project, the dealer's repair invoices usually only listed the parts itemization (without associated parts costs) and repair hours. The parts costs were obtained by presenting the parts lists to the dealership's parts counter and acquiring the associated list of costs. The dealer charges the vehicle manufacturer a higher labor rate for warranty repairs than it charges regular customers. Thus, the labor cost was calculated for each repair as the product of the repair hours and the customary labor charge (for individual customers).

As illustrated in Figure 7, the total number of repairs was highly variable: one vehicle required eight repairs in less than 20,000 miles; others did not require any repairs after traveling twice as far. One goal of this study was to examine the additional cost for bi-fuel vehicles relative to gasoline-only vehicles, but the statistical basis for the gasoline-only vehicles is small. For this reason, we also examined the portion of the unscheduled maintenance that resulted from the LPG system. All of the LPG-related maintenance fell within three categories: propane fill valve leaking, propane fuel/switch malfunction, and propane indicator light malfunction. Examples of the non-LPG-related repairs on the bi-fuel vehicles include:

- Flat tire repair

- Starter relay replacement

- Windshield replacement

- Power steering pump replacement 
- Fan belt tensioner replacement

- Front end alignment.

These are examples of repairs that probably would have been required even if these vehicles had not been converted to LPG, as they have nothing to do with the fuel system. For the bi-fuel study vehicles, all required fuel system repairs were LPG-related. This study indicates that the gasoline fueling systems are more reliable than the LPG systems, although vehicles in both categories require repair of systems that are totally unrelated to the fuel. One purpose of this analysis was to project the additional repair costs related to these vehicles having been converted to bi-fuel operation, and incurred after the warranty period.

Three of the four gasoline-only vehicles had repairs, but one of these three had only a flat tire repair. In contrast, 28 of the 31 bi-fuel vehicles required repair. An over-simplified analysis, which overlooks the very small sample size of the gasoline-only vehicle pool, might yield the conclusion that only 15 of every 30 gasoline-only F150s would require repair over the project period. The addition of an LPG system (the bi-fuel vehicles) would appear to result in almost $90 \%$ of these vehicles needing repairs during this time span. However, only 13 of the 31 bi-fuel vehicles required LPG-related repairs. This, again, emphasizes the problem of extrapolating from a small data pool (the four gasoline-only vehicles) for phenomena that are as irregular as repairs.

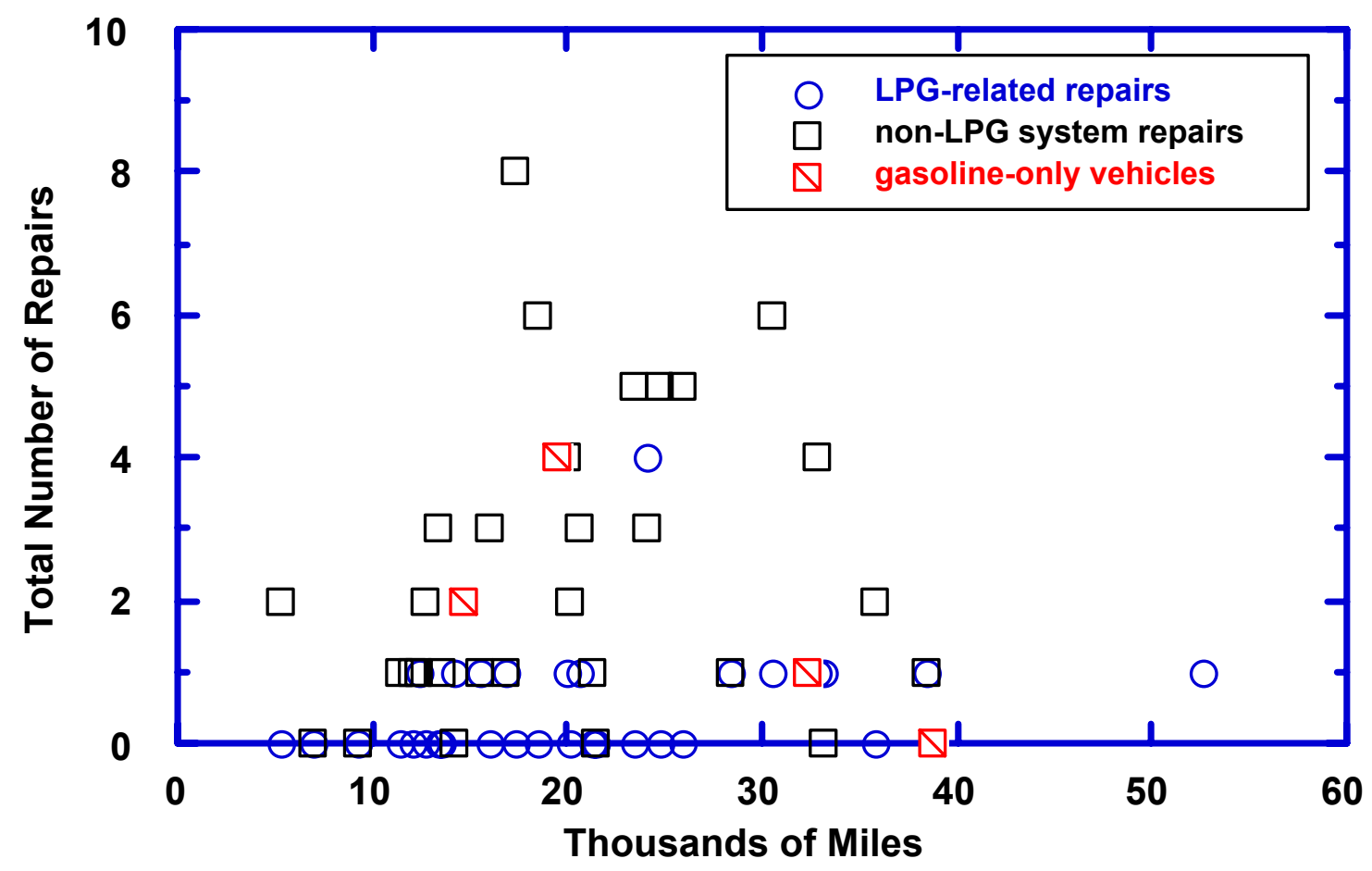

Figure 7. Total number of repairs versus total miles accumulated over the project period. Each vehicle, except the gasoline-only vehicles, has two data points at its final mileage at the end of the project: a circle for the number of LPG system repairs and a square for the number of non-LPG-related repairs.

The limitations of the small gasoline-only data set can be addressed by examining the difference between the LPG-related maintenance and the total unscheduled maintenance; this is the portion of unscheduled 
maintenance that is expected to have occurred even if the vehicle had not been converted to bi-fuel operation. Appendix E presents the summary statistics for the unscheduled maintenance (repairs).

The projected non-LPG-related repair cost for the bi-fuel vehicles is 1.98 cents/mile. This is based on a much larger sample size than is available for the gasoline-only vehicles and includes only repairs that are not related to the LPG system. Therefore, it is assumed that this repair cost of approximately 1.98 cents/mile, after the warranty period, is also applicable to the gasoline-only vehicles.

It is expected that the repair costs for the bi-fuel vehicles will be higher simply because there is additional hardware on these vehicles. On average for the bi-fuel vehicles in this study, the additional hardware for the LPG system adds a projected 0.77 cents/mile to the repair cost of the bi-fuel vehicles. That is, the bi-fuel vehicles are expected to have a repair cost (after the warranty period) that is $39 \%$ higher than that estimated for gasoline-only operation.

\section{Reliability}

We used the number of unscheduled maintenance occurrences per 5,000 miles to evaluate the reliability of the vehicles being studied. Figure 8 presents the results for each of the vehicles and Appendix E provides a statistical summary. The corresponding data are available in Appendix D.

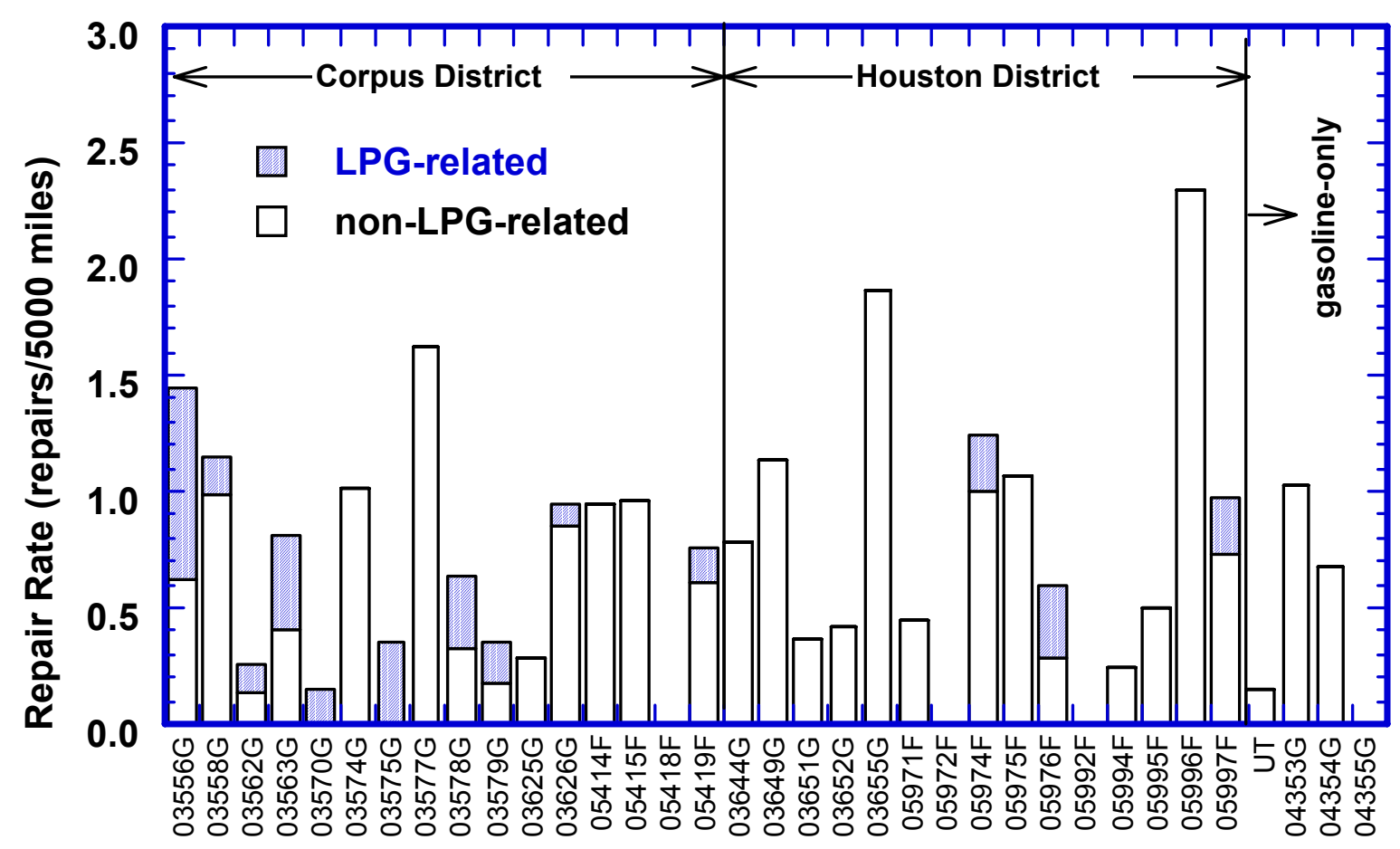

Figure 8. Comparisons of the repair rates for the study vehicles

As discussed in Section E.3 of Appendix E, the repair rates for the gasoline-only vehicles are not statistically different (with at least $95 \%$ confidence) from the non-LPG system repair rates for the bi-fuel vehicles. It is estimated that the baseline repair rate (that expected whether or not the vehicle has a LPG system) is 6.5 repairs per 50,000 miles. On average, the LPG system requires about one repair every 50,000 miles compared to about 7 repairs every 50,000 miles for the remaining systems. The present finding of 1.1 additional repairs every 50,000 miles agrees surprisingly well with that from a previous 
study (Dardalis et al., 1998), which found 1.25 repairs every 50,000 miles but examined only five bi-fuel LPG vehicles.

As expected, gasoline-only vehicles are more reliable than bi-fuel vehicles because bi-fuel vehicles have additional components. However, the reliability of the LPG system is, on average, quite good. On average, about $15 \%$ of unscheduled maintenance is related to the LPG system.

\section{Summary of Operating Costs for Identical Gasoline and Bi-Fuel Vehicles}

The uncertainty in the true means is very high for many of the cost categories of interest to this study (see discussions and analyses in Appendix C and E). This results from the small sample size, especially for the gasoline-only vehicles, and from the fact that many of the cost factors are functions of parameters that could not be held constant during the study: the duty cycle (in-use fuel economy), the miles accumulated annually, the percent use of LPG, and the relative costs of LPG and gasoline. However, the results of this study do allow the costs of identical gasoline-only and bi-fuel vehicles to be calculated.

To perform the calculations to allow comparison of the operating costs of bi-fuel vehicles with those of gasoline-only vehicles, those factors that could not be held constant for the study vehicles must be specified. These specifications are enumerated below.

On average, the vehicles in the study fleet traveled 17,153 miles per year. The State of Texas would assess an annual alternative fuels tax of $\$ 168$ per year for bi-fuel vehicles that accumulate more than 15,000 miles per year. Therefore, the cost for this annual tax would be 0.979 cents/mile for a bi-fuel vehicle that accumulates 17,153 miles per year. This cost replaces the state road tax on gasoline that is paid at the pump.

On average, the fuel economy of the study vehicles was $\sim 12.7$ miles per equivalent gallon of gasoline. Because of the differences in energy densities between gasoline and LPG, a bi-fuel vehicle that achieves 12.7 mpegg will get 12.7 mpg when operating on gasoline and 9.3 miles per actual LPG gallon when operating on LPG. On average, for the bi-fuel vehicles in this study, LPG accounted for $\sim 78 \%$ of the total gallons of fuel used (gasoline plus LPG). A bi-fuel vehicle that has a fuel economy of $12.7 \mathrm{mpegg}$ and uses LPG $78 \%$ of the time will have a fuel economy of 10.08 miles per actual gallon of LPG plus gasoline.

The fuel operating cost also depends on the difference between the prices of gasoline and LPG (the spread or margin). This margin determines whether or not there will be a fuel operating cost benefit or penalty for operation on LPG, and the size of this benefit or penalty. For the purpose of this analysis, the margin is taken from the average fuel prices during this study: 79.79 cents/gallon for gasoline, 61.75 cents/actual LPG gallon in the Corpus district, and 49.52 cents/actual LPG gallon in the Houston district. For the assumed $78 \%$ use of LPG and $12.7 \mathrm{mpegg}$, these price differences correspond to fuel operating costs of 6.28 cents/mile, 6.51 cents/mile, and 5.53 cents/mile, respectively.

Because TxDOT performs routine scheduled maintenance on a fixed (fuel independent) schedule, the scheduled maintenance operating cost was not statistically different for the gasoline-only vehicles and the bi-fuel vehicles in the Houston District (at $\sim 65$ cents/mile). Because of the high labor cost for the reusable oil filters in the Corpus District, their cost for routine scheduled maintenance was 82 cents $/$ mile. Although the additional maintenance cost of the reusable oil filters is not related to the fact that these are bi-fuel vehicles, this cost is accounted for in this analysis for the sake of completeness. 
Three of the 35 study vehicles came out of warranty near the end of the project. Therefore, there were essentially no repair (unscheduled maintenance) costs for the study fleet. However, because TxDOT keeps vehicles for much longer than the warranty period, projections were made for the repair costs after expiration of the warranty. As discussed in Section 3.B, it is projected that the base repair cost is 1.98 cents/mile independent of whether or not it is a bi-fuel vehicle, but that the LPG system adds an additional 0.77 cents/mile to the repair cost after the warranty period.

Table 4 summarizes the costs calculated for identical bi-fuel and gasoline-only vehicles that travel 17,153 miles per year, have a fuel economy of $12.7 \mathrm{mpegg}$, and conform to the other specifications enumerated above. Before the warranty expires, bi-fuel vehicles in the Houston district have a cost of 0.23 cents/mile more than identical gasoline vehicles for the cost categories considered in this study. This relatively small penalty could be diminished to zero, or become a cost benefit, with more miles accumulated per year (which diminishes the annual tax on a per-mile basis). This penalty could also be diminished by a lower rate for the annual tax on the alternative fuels in Texas, or via a somewhat lower price for LPG. For the Corpus district, during the warranty period, the bi-fuel vehicles cost 1.38 cents/mile more to operate than gasoline-only vehicles that do not use reusable oil filters. Of this additional $1.38 \mathrm{cents} / \mathrm{mile}, 0.17 \mathrm{cents} / \mathrm{mile}$ is due to the higher scheduled maintenance cost for the reusable oil filters with the remainder resulting from the relatively high cost of LPG in the Corpus district (the Corpus district pays more per energy equivalent gallon for LPG than it does for gasoline). In other

Table 4. Summary of Costs for Bi-Fuel and Gasoline-Only Vehicles (cents/mile)

\begin{tabular}{|l|r|r|r|}
\cline { 2 - 4 } \multicolumn{1}{c|}{} & \multicolumn{1}{c|}{$\begin{array}{c}\text { gasoline- } \\
\text { only }\end{array}$} & \multicolumn{1}{c|}{$\begin{array}{c}\text { Corpus } \\
\text { bi-fuel }\end{array}$} & $\begin{array}{c}\text { Houston } \\
\text { bi-fuel }\end{array}$ \\
\hline \% LPG & 0 & \multicolumn{1}{c|}{78} & \multicolumn{1}{c|}{78} \\
\hline fuel cost per mile & 6.28 & 6.51 & 5.53 \\
\hline annual tax (per mile) & 0 & 0.98 & 0.98 \\
\hline scheduled maint. cost per mile & 0.65 & 0.82 & 0.65 \\
\hline projected repair cost per mile & 1.98 & 1.98 & 1.98 \\
\hline projected LPG-related repairs & 0 & 0.77 & 0.77 \\
\hline Total during warranty & $\mathbf{6 . 9 3}$ & $\mathbf{8 . 3 1}$ & $\mathbf{7 . 1 6}$ \\
\hline Projected total after warranty & $\mathbf{8 . 9 1}$ & $\mathbf{1 1 . 0 6}$ & $\mathbf{9 . 9 1}$ \\
\hline
\end{tabular}

words, during the warranty period, the bi-fuel vehicle in Houston costs $3.2 \%$ more per mile to operate and the bi-fuel vehicle in Corpus costs $19.9 \%$ more per mile than the comparable gasoline-only vehicle for the cost factors considered in this study. For the Corpus district, the cost of the bi-fuel vehicle would be $17.5 \%$ higher if both had replacement-type oil filters.

After the warranty expires, it is projected that the bi-fuel vehicles will cost an additional 0.77 cents $/ \mathrm{mile}$ (on top of the costs during the warranty period plus a baseline repair cost of 1.98 cents/mile) because of the repair costs for the LPG systems. After the warranty expires, then, the operating costs for the bi-fuel vehicle will be $11.2 \%$ higher than for the gasoline-only vehicle in the Houston district. For the Corpus district, the cost of the bi-fuel vehicle will be $24.1 \%$ higher than for the gasoline-only vehicle (this would be an additional cost of $22.2 \%$ if both had replacement-type oil filters).

\section{Summary and Conclusions}

Thirty-one bi-fuel pickups were studied over a 2-year period, during which detailed operational and maintenance data and cost were acquired for 18 months. Four nominally identical gasoline-only vehicles 
were leased for comparison. All but one of these vehicles was used for normal daily service in the largest fleet in Texas, which is operated by TxDOT.

Two of the operating costs for bi-fuel vehicles were examined: fuel and maintenance. The maintenance items were categorized into scheduled maintenance and repairs; the latter was further divided into repairs to the LPG system and repairs that were not related to the LPG system. Essentially all the repairs were covered under warranty. However, TxDOT keeps its vehicles until well after the warranty expires. Therefore, details regarding the repairs during the warranty period were used to project repair costs following the warranty's expiration.

On average, the vehicles in the study fleet traveled about 17,000 miles per year (near the average for TxDOT's overall fleet). For the bi-fuel vehicles, LPG accounted for $\sim 78 \%$ of the total gallons of fuel used (gasoline plus LPG).

On average, the fuel economy of the study vehicles was $\sim 12.7$ miles per equivalent gallon of gasoline. This is much lower than the rated fuel economy of this vehicle, illustrating the importance of duty cycle on fuel economy. Because of the differences in energy densities between gasoline and LPG, a bi-fuel vehicle that achieves 12.7 mpegg will get $12.7 \mathrm{mpg}$ when operating on gasoline and 9.3 miles per actual LPG gallon when operating on LPG. If this bi-fuel vehicle averages $78 \%$ use of LPG, as was the case for the study fleet, it will have a fuel economy of 10.08 miles per actual gallon of LPG plus gasoline. Texas' annual tax on alternative fuels was also quantified on a cost-per-mile basis.

Because TxDOT performs routine scheduled maintenance on a fixed (fuel-independent) schedule, the scheduled maintenance operating cost (cents/mile) was not statistically different for the bi-fuel and gasoline-only vehicles. However, in the Corpus district, the bi-fuel vehicles followed the same schedule but used permanent oil filters on these vehicles, which resulted in higher costs for scheduled maintenance resulting from the increased labor cost to clean the filters. The additional hardware (for the LPG systems) on the bi-fuel vehicles resulted, as expected, in additional repairs; on average there were 1.1 LPG-system repairs per 50,000 miles. Overall, about $15 \%$ of the repairs resulted from the LPG system.

\section{References}

Chiu, J., and R.D. Matthews, 1996, "The Texas Project: Part 2-Investigation of Calibrations of Aftermarket CNG and LPG Conversion Technologies," SAE Paper 962099, also in: Journal of Fuels and Lubricants 105:2206, 1996.

Dardalis, D., R.D. Matthews, D. Lewis, and K. Davis, 1998, "The Texas Project Part 5-Economic Analysis: CNG and LPG Conversions of Light-Duty Vehicle Fleets," SAE Paper 982447; also in: Alternative Fuels, SAE Special Publication SP-1391, pp. 43-56.

Herridge, J.T., and J.E. Lambert, 1995, "Fleet Economic Analysis-CleanFleet Alternative Fuels Project," SAE Paper 950395.

Hochhauser, A.M., J.D. Benson, V.R. Burns, R.A. Gorse, Jr., W.J. Koehl, L.J. Painter, R.M. Reuter, and J.A. Rutherford, 1993, "Fuel Composition Effects on Automotive Fuel Economy-The Auto/Oil Air Quality Improvement Research Program," SAE Paper 930138; also in: Auto/Oil Air Quality Improvement Research Program - Volume II, SAE Special Publication SP-1000.

Matthews, R.D., J. Chiu, J. Zheng, D.-Y. Wu, D. Dardalis, K. Shen, C. Roberts, M.J. Hall, J.L. Ellzey, C. Mock, R.B. Wicker, and S. Jaeger, 1996, "The Texas Project: Part 1-Emissions and Fuel Economy of Aftermarket CNG and LPG Conversions of Light-Duty Vehicles," SAE Paper 962098, also in: Journal of Fuels and Lubricants, 105:2186, 1996. 
Wang, Q., D. Sperling, and J. Olmstead, 1993, "Emission Control Cost Effectiveness of Alternative-Fuel Vehicles," SAE Paper 931841.

Wu, D.-Y., R.D. Matthews, J. Zheng, K. Shen, J.P. Chiu, and C. Mock, 1996, "The Texas Project Part 3 - Off-Cycle Emissions of Light-Duty Vehicles Operating on CNG, LPG, Federal Phase 1 Reformulated Gasoline, and/or Low Sulfur Certification Gasoline," SAE Paper 962100, also in: Topics of Alternative Fuels and Their Emissions, SAE Special Publication SP-1208, 1996.

Wu, D.-Y., R.D. Matthews, E. Popova, and C. Mock, 1998a, "The Texas Project Part 4-Final Results: Emissions and Fuel Economy of CNG and LPG Conversions of Light-Duty Vehicles," SAE Paper 982446; also in: Alternative Fuels, SAE Special Publication SP-1391, pp. 21-42.

Wu, D.-Y., D. Dardalis, R.D. Matthews, M.J. Hall, and J.L. Ellzey, 1998b, The Texas Project: Conversions of Light-Duty Vehicles to CNG and LPG - Final Report, submitted to the National Renewable Energy Laboratory.

\section{Contacts}

For more information about this project, please contact any of the following:

\section{Yiqun Huang}

Department of Mechanical Engineering

Mail Code C2200

The University of Texas

Austin, TX 78712

Phone: 512-471-7025

Fax: 512-471-1045

e-mail: yiqun.huang@mail.utexas.edu

\section{Ron Matthews}

Department of Mechanical Engineering

Mail Code C2200

The University of Texas

Austin, TX 78712

Phone: 512-471-3108

Fax: 512-471-1045

e-mail: rdmatt@mail.utexas.edu

\section{Elmira Popova}

Department of Mechanical Engineering Mail Code C2200

The University of Texas

Austin, TX 78712

Phone: 512-471-3078

Fax: 512-471-8727

e-mail: elmira@blacksea.me.utexas.edu 
Appendix A

Monthly Data Regarding Fuel Use

(from log forms) 
Table A.1. Monthly Fuel Use Data from Vehicle Operation Log Forms

\begin{tabular}{|c|c|c|c|c|c|c|c|c|c|c|c|}
\hline \multicolumn{12}{|c|}{ June-97 } \\
\hline $\begin{array}{l}\text { TxDOT Eqpt. } \\
\text { No. }\end{array}$ & type & miles this mo. & $\begin{array}{c}\text { gasoline used } \\
\text { (gallons) }\end{array}$ & $\begin{array}{c}\text { LPG used (act. } \\
\text { gallons) }\end{array}$ & $\begin{array}{c}\text { gasoline cost } \\
(\$)\end{array}$ & LPG $\operatorname{cost}(\$)$ & $\begin{array}{l}\text { tot. equiv } \\
\text { gallons }\end{array}$ & $\begin{array}{l}\text { total fuel cost } \\
(\$)\end{array}$ & mi/act. gallon & MPEGG & $\begin{array}{c}\text { FOC } \\
\text { (cents/mile) }\end{array}$ \\
\hline 03556G & bi-fuel & 1001.00 & 0.00 & 156.60 & 0.00 & 101.99 & 115.15 & 101.99 & 6.39 & 8.69 & 10.19 \\
\hline 03558G & bi-fuel & 2581.00 & 0.00 & 227.00 & 0.00 & 147.85 & 166.91 & 147.85 & 11.37 & 15.46 & 5.73 \\
\hline $03562 \mathrm{G}$ & bi-fuel & 2011.00 & 52.40 & 169.30 & 45.33 & 110.27 & 176.89 & 155.59 & 9.07 & 11.37 & 7.74 \\
\hline $03563 G$ & bi-fuel & 715.00 & 11.00 & 0.00 & 9.52 & 0.00 & 11.00 & 9.52 & 65.00 & 65.00 & 1.33 \\
\hline 03570G & bi-fuel & 517.00 & 0.00 & 82.00 & 0.00 & 53.41 & 60.29 & 53.41 & 6.30 & 8.57 & 10.33 \\
\hline 03574G & bi-fuel & 716.00 & 70.00 & 0.00 & 60.55 & 0.00 & 70.00 & 60.55 & 10.23 & 10.23 & 8.46 \\
\hline $03575 \mathrm{G}$ & bi-fuel & 535.00 & 0.00 & 73.90 & 0.00 & 48.13 & 54.34 & 48.13 & 7.24 & 9.85 & 9.00 \\
\hline $03577 \mathrm{G}$ & bi-fuel & 1255.00 & 17.00 & 40.00 & 14.71 & 26.05 & 46.41 & 40.76 & 22.02 & 27.04 & 3.25 \\
\hline $03578 \mathrm{G}$ & bi-fuel & & & & & & & & & & \\
\hline 03579G & bi-fuel & 2655.00 & 0.00 & 208.60 & 0.00 & 135.86 & 153.38 & 135.86 & 12.73 & 17.31 & 5.12 \\
\hline 03625G & bi-fuel & 1428.00 & 14.00 & 126.70 & 12.11 & 82.52 & 107.16 & 94.63 & 10.15 & 13.33 & 6.63 \\
\hline $03626 \mathrm{G}$ & bi-fuel & 2783.00 & 0.00 & 284.00 & 0.00 & 184.97 & 208.82 & 184.97 & 9.80 & 13.33 & 6.65 \\
\hline $04355 \mathrm{G}$ & gasoline & 2325.00 & 135.70 & & 117.38 & & 135.70 & 117.38 & 17.13 & 17.13 & 5.05 \\
\hline $05414 \mathrm{~F}$ & bi-fuel & 645.00 & 11.50 & 68.00 & 9.95 & 44.29 & 61.50 & 54.24 & 8.11 & 10.49 & 8.41 \\
\hline $05415 \mathrm{~F}$ & bi-fuel & 1038.00 & 0.00 & 119.00 & 0.00 & 77.50 & 87.50 & 77.50 & 8.72 & 11.86 & 7.47 \\
\hline $05418 \mathrm{~F}$ & bi-fuel & & 9.00 & 35.70 & 7.79 & 23.25 & 35.25 & 31.04 & & & \\
\hline $05419 \mathrm{~F}$ & bi-fuel & 986.00 & & 80.00 & 0.00 & 52.10 & 58.82 & 52.10 & 12.33 & 16.76 & 5.28 \\
\hline $03644 \mathrm{G}$ & bi-fuel & 1052.00 & 24.30 & 109.40 & 21.02 & 57.87 & 104.74 & 78.89 & 7.87 & 10.04 & 7.50 \\
\hline 03649G & bi-fuel & 983.00 & 6.00 & 102.30 & 5.19 & 54.12 & 81.22 & 59.31 & 9.08 & 12.10 & 6.03 \\
\hline $03651 \mathrm{G}$ & bi-fuel & 782.00 & 13.00 & 83.00 & 11.25 & 43.91 & 74.03 & 55.15 & 8.15 & 10.56 & 7.05 \\
\hline $03652 \mathrm{G}$ & bi-fuel & 1016.00 & 11.00 & 108.00 & 9.52 & 57.13 & 90.41 & 66.65 & 8.54 & 11.24 & 6.56 \\
\hline $03655 \mathrm{G}$ & bi-fuel & 563.00 & 11.50 & 38.90 & 9.95 & 20.58 & 40.10 & 30.53 & 11.17 & 14.04 & 5.42 \\
\hline $04353 \mathrm{G}$ & gasoline & 1401.00 & 105.90 & & 91.60 & & 105.90 & 91.60 & 13.23 & 13.23 & 6.54 \\
\hline $04354 \mathrm{G}$ & gasoline & 951.00 & 69.80 & & 60.38 & & 69.80 & 60.38 & 13.62 & 13.62 & 6.35 \\
\hline $05971 \mathrm{~F}$ & bi-fuel & 169.00 & 0.00 & 41.00 & 0.00 & 21.69 & 30.15 & 21.69 & 4.12 & 5.61 & 12.83 \\
\hline 05972F & bi-fuel & 479.00 & 10.40 & 20.40 & 9.00 & 10.79 & 25.40 & 19.79 & 15.55 & 18.86 & 4.13 \\
\hline $05974 \mathrm{~F}$ & bi-fuel & 1061.00 & 25.00 & 98.00 & 21.63 & 51.84 & 97.06 & 73.47 & 8.63 & 10.93 & 6.92 \\
\hline $05975 \mathrm{~F}$ & bi-fuel & 1528.00 & 0.00 & 120.00 & 0.00 & 63.48 & 88.24 & 63.48 & 12.73 & 17.32 & 4.15 \\
\hline $05976 \mathrm{~F}$ & bi-fuel & 609.00 & 0.00 & 21.00 & 0.00 & 11.11 & 15.44 & 11.11 & 29.00 & 39.44 & 1.82 \\
\hline $05992 \mathrm{~F}$ & bi-fuel & 1102.00 & 11.00 & 78.90 & 9.52 & 41.74 & 69.01 & 51.25 & \begin{tabular}{|l|}
12.26 \\
\end{tabular} & 15.97 & 4.65 \\
\hline $05994 \mathrm{~F}$ & bi-fuel & 1096.00 & 14.00 & 156.30 & 12.11 & 82.68 & 128.93 & 94.79 & \begin{tabular}{ll|}
6.44 \\
\end{tabular} & 8.50 & 8.65 \\
\hline $05995 \mathrm{~F}$ & bi-fuel & 1492.00 & 11.00 & 163.00 & 9.52 & 86.23 & 130.85 & 95.74 & 8.57 & 11.40 & 6.42 \\
\hline 05996F & bi-fuel & 615.00 & 10.00 & 69.00 & 8.65 & 36.50 & 60.74 & 45.15 & 7.78 & 10.13 & 7.34 \\
\hline 05997F & bi-fuel & 1764.00 & 23.10 & 171.60 & 19.98 & 90.78 & 149.28 & 110.76 & 9.06 & 11.82 & 6.28 \\
\hline UT & gasoline & 112.00 & 15.80 & & 13.67 & & 15.80 & \begin{tabular}{|l|}
13.67 \\
\end{tabular} & 7.09 & 7.09 & 12.20 \\
\hline
\end{tabular}


Table A.1. Monthly Fuel Use Data from Vehicle Operation Log Forms

\begin{tabular}{|c|c|c|c|c|c|c|c|c|c|c|c|}
\hline \multicolumn{12}{|c|}{ July-97 } \\
\hline $\begin{array}{l}\text { TxDOT Eqpt. } \\
\text { No. }\end{array}$ & type & miles this mo. & $\begin{array}{c}\text { gasoline used } \\
\text { (gallons) }\end{array}$ & $\begin{array}{c}\text { LPG used (act. } \\
\text { gallons) }\end{array}$ & $\begin{array}{c}\text { gasoline cost } \\
(\$)\end{array}$ & LPG $\operatorname{cost}(\$)$ & $\begin{array}{l}\text { tot. equiv } \\
\text { gallons }\end{array}$ & $\begin{array}{l}\text { total fuel cost } \\
(\$)\end{array}$ & mi/act. gallon & MPEGG & $\begin{array}{c}\text { FOC } \\
\text { (cents/mile) }\end{array}$ \\
\hline $03556 \mathrm{G}$ & bi-fuel & 1373.00 & 17.00 & 121.00 & 14.64 & 79.34 & 105.97 & 93.98 & 9.95 & 12.96 & 6.84 \\
\hline 03558G & bi-fuel & 2716.00 & 0.00 & 295.80 & 0.00 & 193.96 & 217.50 & 193.96 & 9.18 & 12.49 & 7.14 \\
\hline $03562 \mathrm{G}$ & bi-fuel & 2999.00 & 56.40 & 192.40 & 48.55 & 126.16 & 197.87 & 174.71 & 12.05 & 15.16 & 5.83 \\
\hline $03563 G$ & bi-fuel & 378.00 & 14.00 & 25.00 & 12.05 & 16.39 & 32.38 & 28.45 & 9.69 & 11.67 & 7.53 \\
\hline 03570G & bi-fuel & 2046.00 & 64.00 & 207.20 & 55.10 & 135.86 & 216.35 & 190.96 & 7.54 & 9.46 & 9.33 \\
\hline 03574G & bi-fuel & 2481.00 & 189.30 & 0.00 & 162.97 & 0.00 & 189.30 & 162.97 & 13.11 & 13.11 & 6.57 \\
\hline $03575 \mathrm{G}$ & bi-fuel & 307.00 & 11.00 & 0.00 & 9.47 & 0.00 & 11.00 & 9.47 & 27.91 & 27.91 & 3.08 \\
\hline $03577 \mathrm{G}$ & bi-fuel & 2199.00 & 70.00 & 167.00 & 60.26 & 109.50 & 192.79 & 169.76 & 9.28 & 11.41 & 7.72 \\
\hline 03578G & bi-fuel & & & & & & & & & & \\
\hline 03579G & bi-fuel & 1834.00 & 0.00 & 184.40 & 0.00 & 120.91 & 135.59 & 120.91 & 9.95 & 13.53 & 6.59 \\
\hline 03625G & bi-fuel & & & & & & & & & & \\
\hline $03626 \mathrm{G}$ & bi-fuel & 2653.00 & 0.00 & 219.00 & 0.00 & 143.60 & 161.03 & 143.60 & 12.11 & 16.48 & 5.41 \\
\hline $04355 \mathrm{G}$ & gasoline & 2946.00 & 199.50 & & 171.75 & & 199.50 & 171.75 & 14.77 & 14.77 & 5.83 \\
\hline $05414 \mathrm{~F}$ & bi-fuel & 1546.00 & 45.50 & 69.80 & \begin{tabular}{|c|}
39.17 \\
\end{tabular} & 45.77 & 96.82 & 84.94 & 13.41 & 15.97 & 5.49 \\
\hline $05415 \mathrm{~F}$ & bi-fuel & & & & & & & & & & \\
\hline $05418 \mathrm{~F}$ & bi-fuel & 1176.00 & 8.00 & 94.00 & 6.89 & 61.64 & 77.12 & 68.52 & 11.53 & 15.25 & 5.83 \\
\hline $05419 \mathrm{~F}$ & bi-fuel & 2966.00 & 19.00 & 159.80 & 16.36 & 104.78 & 136.50 & 121.14 & 16.59 & 21.73 & 4.08 \\
\hline $03644 \mathrm{G}$ & bi-fuel & 913.00 & 26.30 & 68.90 & 22.64 & 36.75 & 76.96 & 59.39 & 9.59 & 11.86 & 6.51 \\
\hline 03649G & bi-fuel & 1008.00 & 4.00 & 105.80 & 3.44 & 56.43 & 81.79 & 59.88 & 9.18 & 12.32 & 5.94 \\
\hline $03651 \mathrm{G}$ & bi-fuel & 1302.00 & 26.00 & 139.90 & 22.38 & 74.62 & 128.87 & 97.01 & 7.85 & 10.10 & 7.45 \\
\hline $03652 \mathrm{G}$ & bi-fuel & 1264.00 & 0.00 & 120.00 & 0.00 & 64.01 & 88.24 & 64.01 & 10.53 & 14.33 & 5.06 \\
\hline $03655 \mathrm{G}$ & bi-fuel & 345.00 & 0.00 & 13.50 & 0.00 & 7.20 & 9.93 & 7.20 & 25.56 & 34.76 & 2.09 \\
\hline $04353 G$ & gasoline & 1383.00 & 101.90 & & 87.73 & & 101.90 & 87.73 & 13.57 & 13.57 & 6.34 \\
\hline $04354 \mathrm{G}$ & gasoline & 1049.00 & 88.00 & & 75.76 & & 88.00 & 75.76 & 11.92 & 11.92 & 7.22 \\
\hline $05971 \mathrm{~F}$ & bi-fuel & 1046.00 & 24.00 & 118.10 & 20.66 & 62.99 & 110.84 & 83.66 & 7.36 & 9.44 & 8.00 \\
\hline 05972F & bi-fuel & 558.00 & 15.40 & 20.00 & 13.26 & 10.67 & 30.11 & 23.93 & 15.76 & 18.53 & 4.29 \\
\hline $05974 \mathrm{~F}$ & bi-fuel & 1386.00 & 13.00 & 131.00 & 11.19 & 69.88 & 109.32 & 81.07 & 9.63 & 12.68 & 5.85 \\
\hline $05975 \mathrm{~F}$ & bi-fuel & 1554.00 & 15.00 & 199.00 & 12.91 & 106.15 & 161.32 & 119.06 & 7.26 & 9.63 & 7.66 \\
\hline $05976 \mathrm{~F}$ & bi-fuel & 1634.00 & 28.20 & 146.00 & 24.28 & 77.88 & 135.55 & 102.15 & 9.38 & 12.05 & 6.25 \\
\hline $05992 \mathrm{~F}$ & bi-fuel & 1879.00 & 36.00 & 219.20 & 30.99 & 116.92 & 197.18 & 147.91 & 7.36 & 9.53 & 7.87 \\
\hline $05994 \mathrm{~F}$ & bi-fuel & 1143.00 & 0.00 & 119.20 & 0.00 & 63.58 & 87.65 & 63.58 & 9.59 & 13.04 & 5.56 \\
\hline $05995 \mathrm{~F}$ & bi-fuel & 1368.00 & 0.00 & 135.40 & 0.00 & 72.22 & 99.56 & 72.22 & 10.10 & 13.74 & 5.28 \\
\hline 05996F & bi-fuel & 961.00 & 0.00 & 125.00 & 0.00 & 66.68 & 91.91 & 66.68 & 7.69 & 10.46 & 6.94 \\
\hline 05997F & bi-fuel & 2405.00 & 3.20 & 145.30 & 2.75 & 77.50 & 110.04 & 80.26 & 16.20 & 21.86 & 3.34 \\
\hline UT & gasoline & 931.00 & 61.80 & & 53.20 & & 61.80 & 53.20 & 15.06 & 15.06 & 5.71 \\
\hline
\end{tabular}


Table A.1. Monthly Fuel Use Data from Vehicle Operation Log Forms

\begin{tabular}{|c|c|c|c|c|c|c|c|c|c|c|c|}
\hline \multicolumn{12}{|c|}{ August-97 } \\
\hline $\begin{array}{l}\text { TxDOT Eqpt. } \\
\text { No. }\end{array}$ & type & miles this mo. & $\begin{array}{c}\text { gasoline used } \\
\text { (gallons) }\end{array}$ & $\begin{array}{c}\text { LPG used (act. } \\
\text { gallons) }\end{array}$ & $\begin{array}{c}\text { gasoline cost } \\
(\$)\end{array}$ & LPG cost (\$) & $\begin{array}{l}\text { tot. equiv } \\
\text { gallons }\end{array}$ & $\begin{array}{l}\text { total fuel cost } \\
(\$)\end{array}$ & mi/act. gallon & MPEGG & $\begin{array}{c}\text { FOC } \\
\text { (cents/mile) }\end{array}$ \\
\hline 03556G & bi-fuel & 768.00 & 49.70 & 40.00 & 43.56 & 27.06 & 79.11 & 70.63 & 8.56 & 9.71 & 9.20 \\
\hline 03558G & bi-fuel & & & & & & & & & & \\
\hline $03562 \mathrm{G}$ & bi-fuel & 2776.00 & 82.40 & 142.40 & 72.22 & 96.35 & 187.11 & 168.57 & 12.35 & 14.84 & 6.07 \\
\hline $03563 G$ & bi-fuel & 321.00 & 0.00 & 44.00 & 0.00 & 29.77 & 32.35 & 29.77 & 7.30 & 9.92 & 9.27 \\
\hline O3570G & bi-fuel & 4285.00 & & & & & & & & & \\
\hline 03574G & bi-fuel & 1523.00 & 112.70 & 0.00 & 98.78 & 0.00 & 112.70 & 98.78 & 13.51 & 13.51 & 6.49 \\
\hline $03575 \mathrm{G}$ & bi-fuel & 669.00 & 35.00 & 33.30 & 30.68 & 22.53 & 59.49 & 53.21 & 9.80 & 11.25 & 7.95 \\
\hline $03577 \mathrm{G}$ & bi-fuel & 2204.00 & 100.00 & 205.00 & 87.65 & 138.70 & 250.74 & 226.35 & 7.23 & 8.79 & 10.27 \\
\hline 03578G & bi-fuel & 1622.00 & 13.00 & 102.10 & 11.39 & 69.08 & 88.07 & 80.48 & 14.09 & 18.42 & 4.96 \\
\hline 03579G & bi-fuel & & 8.00 & 30.50 & 7.01 & 20.64 & 30.43 & 27.65 & & & \\
\hline $03625 G$ & bi-fuel & & & & & & & & & & \\
\hline 03626G & bi-fuel & 3865.00 & 0.00 & 280.00 & 0.00 & 189.45 & 205.88 & 189.45 & 13.80 & 18.77 & 4.90 \\
\hline 04355G & gasoline & 1562.00 & 102.10 & & 89.49 & & 102.10 & 89.49 & 15.30 & 15.30 & 5.73 \\
\hline $05414 \mathrm{~F}$ & bi-fuel & & & & & & & & & & \\
\hline $05415 \mathrm{~F}$ & bi-fuel & & & & & & & & & & \\
\hline $05418 \mathrm{~F}$ & bi-fuel & 1024.00 & 0.00 & 138.00 & 0.00 & 93.37 & 101.47 & 93.37 & 7.42 & 10.09 & 9.12 \\
\hline 05419F & bi-fuel & & & & & & & & & & \\
\hline $03644 \mathrm{G}$ & bi-fuel & 495.00 & 28.70 & 47.20 & 25.16 & 26.16 & 63.41 & 51.32 & 6.52 & 7.81 & 10.37 \\
\hline 03649G & bi-fuel & 368.00 & 0.00 & 37.20 & 0.00 & 20.62 & 27.35 & 20.62 & 9.89 & 13.45 & 5.60 \\
\hline $03651 \mathrm{G}$ & bi-fuel & 775.00 & 18.00 & 73.00 & 15.78 & 40.46 & 71.68 & 56.24 & 8.52 & 10.81 & 7.26 \\
\hline $03652 \mathrm{G}$ & bi-fuel & 1024.00 & 0.00 & 78.00 & 0.00 & 43.24 & 57.35 & 43.24 & 13.13 & 17.85 & 4.22 \\
\hline $03655 \mathrm{G}$ & bi-fuel & 532.00 & 7.80 & 37.40 & 6.84 & 20.73 & 35.30 & 27.57 & 11.77 & 15.07 & 5.18 \\
\hline $04353 G$ & gasoline & 1188.00 & 89.50 & & 78.45 & & 89.50 & 78.45 & 13.27 & 13.27 & 6.60 \\
\hline $04354 \mathrm{G}$ & gasoline & 1207.00 & 80.00 & & 70.12 & & 80.00 & 70.12 & 15.09 & 15.09 & 5.81 \\
\hline $05971 \mathrm{~F}$ & bi-fuel & 1582.00 & 28.00 & 190.20 & 24.54 & 105.43 & 167.85 & 129.97 & 7.25 & 9.42 & 8.22 \\
\hline $05972 \mathrm{~F}$ & bi-fuel & 445.00 & 12.70 & 20.30 & 11.13 & 11.25 & 27.63 & 22.38 & 13.48 & 16.11 & 5.03 \\
\hline $05974 \mathrm{~F}$ & bi-fuel & 1433.00 & 18.00 & 104.00 & 15.78 & 57.65 & 94.47 & 73.42 & 11.75 & 15.17 & 5.12 \\
\hline $05975 \mathrm{~F}$ & bi-fuel & 1734.00 & 21.00 & 160.00 & 18.41 & 88.69 & 138.65 & 107.09 & 9.58 & 12.51 & 6.18 \\
\hline $05976 \mathrm{~F}$ & bi-fuel & 1429.00 & 41.70 & 111.10 & 36.55 & 61.58 & 123.39 & 98.13 & 9.35 & 11.58 & 6.87 \\
\hline $05992 \mathrm{~F}$ & bi-fuel & 1956.00 & 23.00 & 203.50 & 20.16 & 112.80 & 172.63 & 132.96 & 8.64 & 11.33 & 6.80 \\
\hline 05994F & bi-fuel & 880.00 & 14.30 & 104.30 & 12.53 & 57.81 & 90.99 & 70.35 & 7.42 & 9.67 & 7.99 \\
\hline 05995F & bi-fuel & 814.00 & 0.00 & 90.00 & 0.00 & 49.89 & 66.18 & 49.89 & 9.04 & 12.30 & 6.13 \\
\hline 05996F & bi-fuel & 1484.00 & 20.00 & 76.00 & 17.53 & 42.13 & 75.88 & 59.66 & 15.46 & 19.56 & 4.02 \\
\hline $05997 \mathrm{~F}$ & bi-fuel & 668.00 & 27.70 & 23.60 & 24.28 & 13.08 & 45.05 & 37.36 & 13.02 & 14.83 & 5.59 \\
\hline UT & gasoline & 1189.00 & 93.30 & & 81.78 & & 93.30 & 81.78 & 12.74 & 12.74 & 6.88 \\
\hline
\end{tabular}


Table A.1. Monthly Fuel Use Data from Vehicle Operation Log Forms

\begin{tabular}{|c|c|c|c|c|c|c|c|c|c|c|c|}
\hline \multicolumn{12}{|c|}{ September-97 } \\
\hline $\begin{array}{l}\text { TXDOT Eqpt. } \\
\text { No. }\end{array}$ & type & miles this mo. & $\begin{array}{l}\text { gasoline used } \\
\text { (gallons) }\end{array}$ & $\begin{array}{c}\text { LPG used (act. } \\
\text { gallons) }\end{array}$ & $\begin{array}{c}\text { gasoline cost } \\
(\$)\end{array}$ & LPG cost $(\$)$ & $\begin{array}{l}\text { tot. equiv } \\
\text { gallons }\end{array}$ & $\begin{array}{l}\text { total fuel cost } \\
\text { (\$) }\end{array}$ & mi/act. gallon & MPEGG & $\begin{array}{c}\mathrm{FOC} \\
\text { (cents/mile) }\end{array}$ \\
\hline $03556 \mathrm{G}$ & bi-fuel & 1431.00 & & & & & & & & & \\
\hline $03558 \mathrm{G}$ & bi-fuel & & & & & & & & & & \\
\hline $03562 \mathrm{G}$ & bi-fuel & 3339.00 & & & & & & & & & \\
\hline $03563 G$ & bi-fuel & 703.00 & 0.00 & 73.00 & 0.00 & 50.66 & 53.68 & 50.66 & 9.63 & 13.10 & 7.21 \\
\hline $03570 \mathrm{G}$ & bi-fuel & 3557.00 & 11.00 & 334.00 & 9.88 & 231.80 & 256.59 & 241.68 & 10.31 & 13.86 & 6.79 \\
\hline $03574 G$ & bi-fuel & 1261.00 & 67.80 & 34.60 & 60.91 & 24.01 & 93.24 & $\begin{array}{l}84.92 \\
\end{array}$ & 12.31 & 13.52 & 6.73 \\
\hline 03575G & bi-fuel & 262.00 & 9.00 & 35.00 & 8.09 & 24.29 & 34.74 & 32.38 & 5.95 & 7.54 & 12.36 \\
\hline $03577 \mathrm{G}$ & bi-fuel & 2517.00 & 66.00 & 154.40 & 59.29 & 107.15 & 179.53 & 166.45 & 11.42 & 14.02 & 6.61 \\
\hline $03578 \mathrm{G}$ & bi-fuel & 608.00 & 0.00 & 96.40 & 0.00 & 66.90 & 70.88 & 66.90 & 6.31 & 8.58 & 11.00 \\
\hline $03579 \mathrm{G}$ & bi-fuel & & & & & & & & & & \\
\hline $03625 G$ & bi-fuel & & & & & & & & & & \\
\hline $03626 \mathrm{G}$ & bi-fuel & 4148.00 & 0.00 & 377.00 & 0.00 & 261.64 & 277.21 & 261.64 & 11.00 & 14.96 & 6.31 \\
\hline $04355 \mathrm{G}$ & gasoline & & & & & & & & & & \\
\hline $05414 \mathrm{~F}$ & bi-fuel & & & & & & & & & & \\
\hline $05415 \mathrm{~F}$ & bi-fuel & & & & & & & & & & \\
\hline $05418 \mathrm{~F}$ & bi-fuel & 901.00 & 0.00 & 145.00 & 0.00 & 100.63 & 106.62 & 100.63 & 6.21 & 8.45 & 11.17 \\
\hline $05419 \mathrm{~F}$ & bi-fuel & & & & & & & & & & \\
\hline $03644 G$ & bi-fuel & 845.00 & 29.20 & 24.50 & 26.23 & 14.01 & 47.21 & 40.24 & 15.74 & 17.90 & 4.76 \\
\hline $03649 \mathrm{G}$ & bi-fuel & 1303.00 & 79.00 & 32.90 & 70.97 & 18.81 & 103.19 & 89.78 & 11.64 & 12.63 & 6.89 \\
\hline $03651 \mathrm{G}$ & bi-fuel & 555.00 & 0.00 & 20.00 & 0.00 & 11.43 & 14.71 & 11.43 & 27.75 & 37.74 & 2.06 \\
\hline $03652 \mathrm{G}$ & bi-fuel & 1113.00 & 0.00 & 78.00 & 0.00 & 44.59 & 57.35 & 44.59 & \begin{tabular}{l|}
14.27 \\
\end{tabular} & 19.41 & 4.01 \\
\hline $03655 \mathrm{G}$ & bi-fuel & 1105.00 & 10.10 & 111.90 & 9.07 & 63.97 & 92.38 & 73.05 & 9.06 & 11.96 & 6.61 \\
\hline $04353 G$ & gasoline & 1125.00 & 87.90 & & 78.97 & & 87.90 & 78.97 & 12.80 & 12.80 & 7.02 \\
\hline $04354 G$ & gasoline & 787.00 & 71.20 & & 63.97 & & 71.20 & 63.97 & 11.05 & 11.05 & 8.13 \\
\hline $05971 \mathrm{~F}$ & bi-fuel & 1292.00 & 51.00 & 74.30 & 45.82 & 42.48 & 105.63 & 88.30 & 10.31 & 12.23 & 6.83 \\
\hline $05972 \mathrm{~F}$ & bi-fuel & 788.00 & 23.10 & 21.40 & 20.75 & 12.23 & 38.84 & 32.99 & 17.71 & 20.29 & 4.19 \\
\hline $05974 \mathrm{~F}$ & bi-fuel & 1742.00 & 9.00 & 153.00 & 8.09 & 87.47 & 121.50 & 95.56 & 10.75 & 14.34 & 5.49 \\
\hline $05975 \mathrm{~F}$ & bi-fuel & 1786.00 & 111.00 & 53.00 & 99.72 & 30.30 & 149.97 & 130.02 & 10.89 & 11.91 & 7.28 \\
\hline $05976 \mathrm{~F}$ & bi-fuel & 1499.00 & 68.70 & 57.00 & 61.72 & 32.59 & 110.61 & 94.31 & 11.93 & 13.55 & 6.29 \\
\hline $05992 \mathrm{~F}$ & bi-fuel & 1690.00 & 0.00 & 193.60 & 0.00 & 110.68 & 142.35 & 110.68 & \begin{tabular}{|c|}
8.73 \\
\end{tabular} & 11.87 & 6.55 \\
\hline $05994 \mathrm{~F}$ & bi-fuel & 857.00 & 62.00 & 30.50 & 55.70 & 17.44 & 84.43 & $\begin{array}{ll}73.14 \\
\end{array}$ & 9.26 & 10.15 & 8.53 \\
\hline $05995 \mathrm{~F}$ & bi-fuel & 1310.00 & 7.00 & 170.00 & 6.29 & 97.19 & 132.00 & 103.48 & 7.40 & 9.92 & 7.90 \\
\hline $05996 \mathrm{~F}$ & bi-fuel & 1165.00 & 28.00 & 63.00 & 25.16 & 36.02 & 74.32 & 61.17 & 12.80 & 15.67 & 5.25 \\
\hline $05997 \mathrm{~F}$ & bi-fuel & 2264.00 & 118.40 & 74.20 & \begin{tabular}{|c|}
106.37 \\
\end{tabular} & 42.42 & 172.96 & 148.79 & 11.75 & 13.09 & 6.57 \\
\hline \begin{tabular}{|l} 
UT \\
\end{tabular} & gasoline & 521.00 & 77.90 & & 69.99 & & 77.90 & $\begin{array}{ll}69.99 \\
\end{array}$ & $\begin{array}{l}6.69 \\
\end{array}$ & 6.69 & 13.43 \\
\hline
\end{tabular}


Table A.1. Monthly Fuel Use Data from Vehicle Operation Log Forms

\begin{tabular}{|c|c|c|c|c|c|c|c|c|c|c|c|}
\hline \multicolumn{12}{|c|}{ October-97 } \\
\hline $\begin{array}{l}\text { TxDOT Eqpt. } \\
\text { No. }\end{array}$ & type & miles this mo. & $\begin{array}{c}\text { gasoline used } \\
\text { (gallons) }\end{array}$ & $\begin{array}{c}\text { LPG used (act. } \\
\text { gallons) }\end{array}$ & $\begin{array}{c}\text { gasoline cost } \\
(\$)\end{array}$ & LPG $\operatorname{cost}(\$)$ & $\begin{array}{l}\text { tot. equiv } \\
\text { gallons }\end{array}$ & $\begin{array}{l}\text { total fuel cost } \\
(\$)\end{array}$ & mi/act. gallon & MPEGG & $\begin{array}{c}\text { FOC } \\
\text { (cents/mile) }\end{array}$ \\
\hline 03556G & bi-fuel & 2531.00 & 10.00 & 262.10 & 8.80 & 184.94 & 202.72 & 193.73 & 9.30 & 12.49 & 7.65 \\
\hline 03558G & bi-fuel & 3999.00 & 56.00 & 293.10 & 49.25 & 206.81 & 271.51 & 256.06 & 11.46 & 14.73 & 6.40 \\
\hline $03562 \mathrm{G}$ & bi-fuel & 1832.00 & 41.00 & 122.30 & 36.06 & 86.29 & 130.93 & 122.35 & 11.22 & 13.99 & 6.68 \\
\hline $03563 G$ & bi-fuel & 1703.00 & 0.00 & 164.00 & 0.00 & 115.72 & 120.59 & 115.72 & 10.38 & 14.12 & 6.79 \\
\hline 03570G & bi-fuel & 2949.00 & 51.00 & 283.90 & 44.85 & 200.32 & 259.75 & 245.17 & 8.81 & 11.35 & 8.31 \\
\hline 03574G & bi-fuel & 2646.00 & 87.00 & 73.80 & 76.52 & 52.07 & 141.26 & 128.59 & 16.46 & 18.73 & 4.86 \\
\hline 03575G & bi-fuel & 646.00 & 0.00 & 45.40 & 0.00 & 32.03 & 33.38 & 32.03 & 14.23 & 19.35 & 4.96 \\
\hline $03577 \mathrm{G}$ & bi-fuel & & & & & 0.00 & & & & & \\
\hline 03578G & bi-fuel & 658.00 & 0.00 & 35.70 & 0.00 & 25.19 & 26.25 & 25.19 & 18.43 & 25.07 & 3.83 \\
\hline 03579G & bi-fuel & & & & & & & & & & \\
\hline 03625G & bi-fuel & & & & & & & & & & \\
\hline $03626 \mathrm{G}$ & bi-fuel & 4360.00 & 0.00 & 414.00 & 0.00 & 292.12 & 304.41 & 292.12 & 10.53 & 14.32 & 6.70 \\
\hline $04355 \mathrm{G}$ & gasoline & & & & & & & & & & \\
\hline $05414 \mathrm{~F}$ & bi-fuel & & & & & & & & & & \\
\hline $05415 \mathrm{~F}$ & bi-fuel & & & & & & & & & & \\
\hline $05418 \mathrm{~F}$ & bi-fuel & 669.00 & 0.00 & 73.00 & 0.00 & 51.51 & 53.68 & 51.51 & 9.16 & 12.46 & 7.70 \\
\hline $05419 \mathrm{~F}$ & bi-fuel & & & & & & & & & & \\
\hline $03644 \mathrm{G}$ & bi-fuel & 937.00 & 47.00 & 71.60 & 41.34 & 41.76 & 99.65 & 83.10 & 7.90 & 9.40 & 8.87 \\
\hline 03649G & bi-fuel & 966.00 & 5.00 & 94.20 & 4.40 & 54.95 & 74.26 & 59.34 & 9.74 & 13.01 & 6.14 \\
\hline $03651 \mathrm{G}$ & bi-fuel & 1048.00 & 28.00 & 81.00 & 24.63 & 47.25 & 87.56 & 71.87 & 9.61 & 11.97 & 6.86 \\
\hline $03652 \mathrm{G}$ & bi-fuel & 481.00 & 20.00 & 49.00 & 17.59 & 28.58 & 56.03 & 46.17 & 6.97 & 8.58 & 9.60 \\
\hline $03655 \mathrm{G}$ & bi-fuel & 903.00 & 0.00 & 74.60 & 0.00 & 43.51 & 54.85 & 43.51 & 12.10 & 16.46 & 4.82 \\
\hline $04353 G$ & gasoline & 1123.00 & 88.00 & & 77.40 & & 88.00 & 77.40 & 12.76 & 12.76 & 6.89 \\
\hline $04354 \mathrm{G}$ & gasoline & 1128.00 & 73.10 & & 64.29 & & 73.10 & 64.29 & 15.43 & 15.43 & 5.70 \\
\hline $05971 \mathrm{~F}$ & bi-fuel & 887.00 & 10.00 & 61.20 & 8.80 & 35.70 & 55.00 & 44.49 & 12.46 & 16.13 & 5.02 \\
\hline 05972F & bi-fuel & 514.00 & 12.00 & 14.00 & 10.55 & 8.17 & 22.29 & 18.72 & 19.77 & 23.06 & 3.64 \\
\hline $05974 \mathrm{~F}$ & bi-fuel & 1791.00 & 34.00 & 127.00 & 29.90 & 74.08 & 127.38 & 103.98 & 11.12 & 14.06 & 5.81 \\
\hline $05975 \mathrm{~F}$ & bi-fuel & 2057.00 & 154.00 & 25.00 & 135.44 & 14.58 & 172.38 & 150.03 & 11.49 & 11.93 & 7.29 \\
\hline $05976 \mathrm{~F}$ & bi-fuel & 956.00 & 20.90 & 77.10 & \begin{tabular}{|c|}
18.38 \\
\end{tabular} & 44.97 & 77.59 & 63.35 & \begin{tabular}{|l|}
9.76 \\
\end{tabular} & 12.32 & 6.63 \\
\hline $05992 \mathrm{~F}$ & bi-fuel & 2021.00 & 29.00 & 119.70 & 25.51 & 69.82 & 117.01 & 95.33 & 13.59 & 17.27 & 4.72 \\
\hline $05994 \mathrm{~F}$ & bi-fuel & 1384.00 & 0.00 & 141.10 & 0.00 & 82.30 & 103.75 & 82.30 & 9.81 & 13.34 & 5.95 \\
\hline $05995 \mathrm{~F}$ & bi-fuel & 1665.00 & 23.00 & 125.00 & 20.23 & 72.91 & 114.91 & 93.14 & 11.25 & 14.49 & 5.59 \\
\hline 05996F & bi-fuel & 2069.00 & 20.00 & 180.00 & 17.59 & 104.99 & 152.35 & 122.58 & 10.35 & 13.58 & 5.92 \\
\hline 05997F & bi-fuel & 1599.00 & 28.40 & 142.40 & 24.98 & 83.06 & 133.11 & 108.04 & 9.36 & 12.01 & 6.76 \\
\hline UT & gasoline & 2791.00 & 156.00 & & 137.20 & & 156.00 & 137.20 & \begin{tabular}{|c|}
17.89 \\
\end{tabular} & 17.89 & 4.92 \\
\hline
\end{tabular}


Table A.1. Monthly Fuel Use Data from Vehicle Operation Log Forms

\begin{tabular}{|c|c|c|c|c|c|c|c|c|c|c|c|}
\hline \multicolumn{12}{|c|}{ November-97 } \\
\hline $\begin{array}{l}\text { TxDOT Eqpt. } \\
\text { No. }\end{array}$ & type & miles this mo. & $\begin{array}{c}\text { gasoline used } \\
\text { (gallons) }\end{array}$ & $\begin{array}{c}\text { LPG used (act. } \\
\text { gallons) }\end{array}$ & $\begin{array}{c}\text { gasoline cost } \\
(\$)\end{array}$ & LPG $\operatorname{cost}(\$)$ & $\begin{array}{l}\text { tot. equiv } \\
\text { gallons }\end{array}$ & $\begin{array}{l}\text { total fuel cost } \\
(\$)\end{array}$ & mi/act. gallon & MPEGG & $\begin{array}{c}\text { FOC } \\
\text { (cents/mile) }\end{array}$ \\
\hline $03556 \mathrm{G}$ & bi-fuel & 1134.00 & 26.00 & 95.00 & 21.95 & 63.42 & 95.85 & 85.38 & 9.37 & 11.83 & 7.53 \\
\hline 03558G & bi-fuel & 2629.00 & 16.00 & 165.00 & 13.51 & 110.15 & 137.32 & 123.66 & 14.52 & 19.14 & 4.70 \\
\hline $03562 \mathrm{G}$ & bi-fuel & 1702.00 & 19.00 & 108.50 & 16.04 & 72.43 & 98.78 & 88.48 & 13.35 & 17.23 & 5.20 \\
\hline $03563 G$ & bi-fuel & 1645.00 & 0.00 & 80.00 & 0.00 & 53.41 & 58.82 & 53.41 & 20.56 & 27.97 & 3.25 \\
\hline 03570G & bi-fuel & 3138.00 & 50.30 & 247.40 & 42.47 & 165.16 & 232.21 & 207.64 & 10.54 & 13.51 & 6.62 \\
\hline 03574G & bi-fuel & 2071.00 & 83.70 & 89.70 & 70.68 & 59.88 & 149.66 & 130.56 & 11.94 & 13.84 & 6.30 \\
\hline 03575G & bi-fuel & 545.00 & 0.00 & 92.00 & 0.00 & 61.42 & 67.65 & 61.42 & 5.92 & 8.06 & 11.27 \\
\hline $03577 \mathrm{G}$ & bi-fuel & & & & & & & & & & \\
\hline 03578G & bi-fuel & 243.00 & 0.00 & 35.60 & 0.00 & 23.77 & 26.18 & 23.77 & 6.83 & 9.28 & 9.78 \\
\hline 03579G & bi-fuel & & & & & & & & & & \\
\hline 03625G & bi-fuel & & & & & & & & & & \\
\hline $03626 \mathrm{G}$ & bi-fuel & 2387.00 & 0.00 & 181.00 & 0.00 & 120.84 & 133.09 & 120.84 & 13.19 & 17.94 & 5.06 \\
\hline $04355 \mathrm{G}$ & gasoline & & & & & & & & & & \\
\hline $05414 \mathrm{~F}$ & bi-fuel & & & & & & & & & & \\
\hline $05415 \mathrm{~F}$ & bi-fuel & & & & & & & & & & \\
\hline $05418 \mathrm{~F}$ & bi-fuel & 650.00 & 0.00 & 71.00 & 0.00 & 47.40 & 52.21 & 47.40 & 9.15 & 12.45 & 7.29 \\
\hline 05419F & bi-fuel & 2225.00 & 0.00 & 183.90 & 0.00 & 122.77 & 135.22 & 122.77 & 12.10 & 16.45 & 5.52 \\
\hline $03644 \mathrm{G}$ & bi-fuel & 1038.00 & 24.40 & 35.10 & 20.60 & 19.14 & 50.21 & 39.74 & 17.45 & 20.67 & 3.83 \\
\hline 03649G & bi-fuel & 618.00 & 9.00 & 37.00 & 7.60 & 20.18 & 36.21 & 27.78 & 13.43 & 17.07 & 4.49 \\
\hline $03651 \mathrm{G}$ & bi-fuel & 1063.00 & 32.00 & 103.00 & 27.02 & 56.17 & 107.74 & 83.19 & 7.87 & 9.87 & 7.83 \\
\hline $03652 \mathrm{G}$ & bi-fuel & 368.00 & 0.00 & 15.00 & 0.00 & 8.18 & 11.03 & 8.18 & 24.53 & 33.37 & 2.22 \\
\hline $03655 \mathrm{G}$ & bi-fuel & 124.00 & 0.00 & 22.00 & 0.00 & 12.00 & 16.18 & 12.00 & 5.64 & 7.67 & 9.67 \\
\hline $04353 G$ & gasoline & 766.00 & 46.00 & & 38.84 & & 46.00 & 38.84 & 16.65 & 16.65 & 5.07 \\
\hline $04354 \mathrm{G}$ & gasoline & 962.00 & 47.50 & & 40.11 & & 47.50 & 40.11 & 20.25 & 20.25 & 4.17 \\
\hline $05971 \mathrm{~F}$ & bi-fuel & 507.00 & 0.00 & 39.60 & 0.00 & 21.59 & 29.12 & 21.59 & 12.80 & 17.41 & 4.26 \\
\hline 05972F & bi-fuel & 195.00 & 0.00 & 20.40 & 0.00 & 11.12 & 15.00 & 11.12 & 9.56 & 13.00 & 5.70 \\
\hline $05974 \mathrm{~F}$ & bi-fuel & 1192.00 & 0.00 & 100.00 & 0.00 & 54.53 & 73.53 & 54.53 & 11.92 & 16.21 & 4.57 \\
\hline $05975 \mathrm{~F}$ & bi-fuel & 1263.00 & 108.00 & 24.00 & 91.20 & 13.09 & 125.65 & 104.28 & 9.57 & 10.05 & 8.26 \\
\hline $05976 \mathrm{~F}$ & bi-fuel & 861.00 & 9.00 & 75.80 & 7.60 & 41.33 & \begin{tabular}{|c|}
64.74 \\
\end{tabular} & 48.93 & \begin{tabular}{|c|}
10.15 \\
\end{tabular} & 13.30 & 5.68 \\
\hline $05992 \mathrm{~F}$ & bi-fuel & 1773.00 & 15.00 & 174.50 & 12.67 & 95.15 & 143.31 & 107.82 & 9.36 & 12.37 & 6.08 \\
\hline $05994 \mathrm{~F}$ & bi-fuel & 1023.00 & 12.50 & 90.30 & 10.56 & 49.24 & 78.90 & 59.80 & 9.95 & 12.97 & 5.85 \\
\hline $05995 \mathrm{~F}$ & bi-fuel & 1421.00 & 9.00 & 140.00 & 7.60 & 76.34 & 111.94 & 83.94 & 9.54 & 12.69 & 5.91 \\
\hline 05996F & bi-fuel & 1511.00 & 0.00 & 128.00 & 0.00 & 69.80 & 94.12 & 69.80 & 11.80 & 16.05 & 4.62 \\
\hline 05997F & bi-fuel & 1602.00 & 8.00 & 103.30 & 6.76 & 56.33 & 83.96 & 63.08 & 14.39 & 19.08 & 3.94 \\
\hline UT & gasoline & 2021.00 & 116.80 & & 98.63 & & 116.80 & 98.63 & 17.30 & 17.30 & 4.88 \\
\hline
\end{tabular}


Table A.1. Monthly Fuel Use Data from Vehicle Operation Log Forms

\begin{tabular}{|c|c|c|c|c|c|c|c|c|c|c|c|}
\hline \multicolumn{12}{|c|}{ December-97 } \\
\hline $\begin{array}{l}\text { TxDOT Eqpt. } \\
\text { No. }\end{array}$ & type & miles this mo. & $\begin{array}{c}\text { gasoline used } \\
\text { (gallons) }\end{array}$ & $\begin{array}{c}\text { LPG used (act. } \\
\text { gallons) }\end{array}$ & $\begin{array}{c}\text { gasoline cost } \\
(\$)\end{array}$ & LPG $\operatorname{cost}(\$)$ & $\begin{array}{l}\text { tot. equiv } \\
\text { gallons }\end{array}$ & $\begin{array}{l}\text { total fuel cost } \\
(\$)\end{array}$ & mi/act. gallon & MPEGG & $\begin{array}{c}\text { FOC } \\
\text { (cents/mile) }\end{array}$ \\
\hline $03556 \mathrm{G}$ & bi-fuel & & & & & & & & & & \\
\hline 03558G & bi-fuel & 2961.00 & 14.00 & 264.40 & 11.68 & 170.11 & 208.41 & 181.80 & 10.64 & 14.21 & 6.14 \\
\hline $03562 \mathrm{G}$ & bi-fuel & 3203.00 & 96.00 & 210.40 & 80.11 & 135.37 & 250.71 & 215.48 & 10.45 & 12.78 & 6.73 \\
\hline $03563 G$ & bi-fuel & 912.00 & 0.00 & 70.00 & 0.00 & 45.04 & 51.47 & 45.04 & 13.03 & 17.72 & 4.94 \\
\hline 03570G & bi-fuel & 1973.00 & 37.00 & 151.00 & 30.88 & 97.15 & 148.03 & 128.03 & 10.49 & 13.33 & 6.49 \\
\hline 03574G & bi-fuel & 1677.00 & 55.80 & 56.70 & 46.57 & 36.48 & 97.49 & 83.05 & 14.91 & 17.20 & 4.95 \\
\hline $03575 \mathrm{G}$ & bi-fuel & 853.00 & 0.00 & 48.60 & 0.00 & 31.27 & 35.74 & 31.27 & 17.55 & 23.87 & 3.67 \\
\hline $03577 \mathrm{G}$ & bi-fuel & 887.00 & 34.00 & 72.50 & 28.37 & 46.65 & 87.31 & 75.02 & 8.33 & 10.16 & 8.46 \\
\hline 03578G & bi-fuel & 756.00 & 0.00 & 70.10 & 0.00 & 45.10 & 51.54 & 45.10 & 10.78 & 14.67 & 5.97 \\
\hline 03579G & bi-fuel & 877.00 & 14.00 & 62.20 & 11.68 & 40.02 & 59.74 & 51.70 & 11.51 & 14.68 & 5.90 \\
\hline 03625G & bi-fuel & & & & & & & & & & \\
\hline $03626 \mathrm{G}$ & bi-fuel & & & & & & & & & & \\
\hline $04355 \mathrm{G}$ & gasoline & & & & & & & & & & \\
\hline $05414 \mathrm{~F}$ & bi-fuel & & & & & & & & & & \\
\hline $05415 \mathrm{~F}$ & bi-fuel & & & & & & & & & & \\
\hline $05418 \mathrm{~F}$ & bi-fuel & 536.00 & 0.00 & 73.00 & 0.00 & 46.97 & 53.68 & 46.97 & 7.34 & 9.99 & 8.76 \\
\hline 05419F & bi-fuel & & & & & & & & & & \\
\hline $03644 \mathrm{G}$ & bi-fuel & 1011.00 & 22.80 & 67.70 & 19.03 & 35.28 & 72.58 & 54.31 & 11.17 & 13.93 & 5.37 \\
\hline 03649G & bi-fuel & 936.00 & 0.00 & 105.40 & 0.00 & 54.92 & 77.50 & 54.92 & 8.88 & 12.08 & 5.87 \\
\hline $03651 \mathrm{G}$ & bi-fuel & 484.00 & 20.00 & 41.00 & 16.69 & 21.37 & 50.15 & 38.06 & 7.93 & 9.65 & 7.86 \\
\hline $03652 \mathrm{G}$ & bi-fuel & 363.00 & 0.00 & 41.00 & 0.00 & 21.37 & 30.15 & 21.37 & 8.85 & 12.04 & 5.89 \\
\hline $03655 \mathrm{G}$ & bi-fuel & 167.00 & & & & & & & & & \\
\hline $04353 G$ & gasoline & 1137.00 & 81.20 & & 67.76 & & 81.20 & 67.76 & 14.00 & 14.00 & 5.96 \\
\hline $04354 \mathrm{G}$ & gasoline & 1128.00 & 64.30 & & 53.66 & & 64.30 & 53.66 & 17.54 & 17.54 & 4.76 \\
\hline $05971 \mathrm{~F}$ & bi-fuel & 797.00 & 15.00 & 57.50 & 12.52 & 29.96 & 57.28 & 42.48 & 10.99 & 13.91 & 5.33 \\
\hline 05972F & bi-fuel & 350.00 & 10.70 & 0.00 & 8.93 & 0.00 & 10.70 & 8.93 & 32.71 & 32.71 & 2.55 \\
\hline $05974 \mathrm{~F}$ & bi-fuel & 1641.00 & 27.50 & 115.00 & 22.95 & 59.93 & 112.06 & 82.88 & 11.52 & 14.64 & 5.05 \\
\hline $05975 \mathrm{~F}$ & bi-fuel & 1912.00 & 0.00 & 198.00 & 0.00 & 103.18 & 145.59 & 103.18 & 9.66 & 13.13 & 5.40 \\
\hline $05976 \mathrm{~F}$ & bi-fuel & & 0.00 & 5.00 & 0.00 & 2.61 & 3.68 & 2.61 & 0.00 & & \\
\hline $05992 \mathrm{~F}$ & bi-fuel & 1167.00 & 6.00 & 103.00 & 5.01 & 53.67 & 81.74 & 58.68 & 10.71 & 14.28 & 5.03 \\
\hline 05994F & bi-fuel & 1140.00 & 10.50 & 119.10 & 8.76 & 62.06 & 98.07 & 70.83 & 8.80 & 11.62 & 6.21 \\
\hline $05995 \mathrm{~F}$ & bi-fuel & 1741.00 & 9.00 & 157.00 & 7.51 & 81.81 & 124.44 & 89.32 & 10.49 & 13.99 & 5.13 \\
\hline 05996F & bi-fuel & 1703.00 & 0.00 & 170.00 & 0.00 & 88.59 & 125.00 & 88.59 & 10.02 & 13.62 & 5.20 \\
\hline 05997F & bi-fuel & 432.00 & 0.00 & 65.80 & 0.00 & 34.29 & 48.38 & 34.29 & 6.57 & 8.93 & 7.94 \\
\hline UT & gasoline & 3015.00 & 210.80 & & 175.91 & & 210.80 & 175.91 & 14.30 & 14.30 & 5.83 \\
\hline
\end{tabular}


Table A.1. Monthly Fuel Use Data from Vehicle Operation Log Forms

\begin{tabular}{|c|c|c|c|c|c|c|c|c|c|c|c|}
\hline \multicolumn{12}{|c|}{ January-98 } \\
\hline $\begin{array}{l}\text { TxDOT Eqpt. } \\
\text { No. }\end{array}$ & type & miles this mo. & $\begin{array}{c}\text { gasoline used } \\
\text { (gallons) }\end{array}$ & $\begin{array}{c}\text { LPG used (act. } \\
\text { gallons) }\end{array}$ & $\begin{array}{c}\text { gasoline cost } \\
(\$)\end{array}$ & LPG $\operatorname{cost}(\$)$ & $\begin{array}{l}\text { tot. equiv } \\
\text { gallons }\end{array}$ & $\begin{array}{l}\text { total fuel cost } \\
(\$)\end{array}$ & mi/act. gallon & MPEGG & $\begin{array}{c}\text { FOC } \\
\text { (cents/mile) }\end{array}$ \\
\hline $03556 \mathrm{G}$ & bi-fuel & & & & & & & & & & \\
\hline 03558G & bi-fuel & 3067.00 & & & & & & & & & \\
\hline $03562 \mathrm{G}$ & bi-fuel & 1392.00 & & & & & & & & & \\
\hline $03563 G$ & bi-fuel & 955.00 & 0.00 & 79.00 & 0.00 & 48.16 & 58.09 & 48.16 & 12.09 & 16.44 & 5.04 \\
\hline 03570G & bi-fuel & 1690.00 & 10.00 & 108.00 & 8.13 & 65.84 & 89.41 & 73.97 & 14.32 & 18.90 & 4.38 \\
\hline 03574G & bi-fuel & 2083.00 & & & & & & & & & \\
\hline 03575G & bi-fuel & & & & & & & & & & \\
\hline $03577 \mathrm{G}$ & bi-fuel & 1585.00 & 52.00 & 81.00 & 42.28 & 49.38 & 111.56 & 91.65 & 11.92 & 14.21 & 5.78 \\
\hline 03578G & bi-fuel & 780.00 & 0.00 & 74.50 & 0.00 & 45.42 & 54.78 & 45.42 & 10.47 & 14.24 & 5.82 \\
\hline 03579G & bi-fuel & 341.00 & & 42.00 & 0.00 & 25.60 & 30.88 & 25.60 & 8.12 & 11.04 & 7.51 \\
\hline 03625G & bi-fuel & & & & & & & & & & \\
\hline $03626 \mathrm{G}$ & bi-fuel & & & & & & & & & & \\
\hline $04355 \mathrm{G}$ & gasoline & & & & & & & & & & \\
\hline $05414 \mathrm{~F}$ & bi-fuel & & & & & & & & & & \\
\hline $05415 \mathrm{~F}$ & bi-fuel & & & & & & & & & & \\
\hline $05418 \mathrm{~F}$ & bi-fuel & 500.00 & 0.00 & 66.00 & 0.00 & 40.23 & 48.53 & 40.23 & 7.58 & 10.30 & 8.05 \\
\hline $05419 \mathrm{~F}$ & bi-fuel & 2041.00 & 11.00 & 187.60 & 8.94 & 114.36 & 148.94 & 123.30 & 10.28 & 13.70 & 6.04 \\
\hline $03644 \mathrm{G}$ & bi-fuel & 1273.00 & 35.50 & 121.00 & 28.86 & 58.96 & 124.47 & 87.82 & 8.13 & 10.23 & 6.90 \\
\hline 03649G & bi-fuel & 867.00 & 10.00 & 63.40 & 8.13 & 30.89 & 56.62 & 39.02 & 11.81 & 15.31 & 4.50 \\
\hline $03651 \mathrm{G}$ & bi-fuel & 654.00 & 19.00 & 62.00 & 15.45 & 30.21 & 64.59 & 45.66 & 8.07 & 10.13 & 6.98 \\
\hline $03652 \mathrm{G}$ & bi-fuel & 1171.00 & 12.00 & 84.00 & 9.76 & 40.93 & 73.76 & 50.69 & 12.20 & 15.87 & 4.33 \\
\hline $03655 \mathrm{G}$ & bi-fuel & 132.00 & 0.00 & 20.80 & 0.00 & 10.14 & 15.29 & 10.14 & 6.35 & 8.63 & 7.68 \\
\hline $04353 G$ & gasoline & 1829.00 & 104.60 & & 85.04 & & 104.60 & 85.04 & 17.49 & 17.49 & 4.65 \\
\hline 04354G & gasoline & 1126.00 & 54.60 & & 44.39 & & 54.60 & 44.39 & 20.62 & 20.62 & 3.94 \\
\hline $05971 \mathrm{~F}$ & bi-fuel & 420.00 & 22.00 & 21.00 & 17.89 & 10.23 & 37.44 & 28.12 & 9.77 & 11.22 & 6.70 \\
\hline $05972 \mathrm{~F}$ & bi-fuel & 465.00 & 11.20 & 21.60 & 9.11 & 10.53 & 27.08 & 19.63 & 14.18 & 17.17 & 4.22 \\
\hline $05974 \mathrm{~F}$ & bi-fuel & 1554.00 & 0.00 & 101.00 & 0.00 & 49.22 & 74.26 & 49.22 & 15.39 & 20.93 & 3.17 \\
\hline $05975 \mathrm{~F}$ & bi-fuel & 1678.00 & 0.00 & 172.00 & 0.00 & 83.82 & 126.47 & 83.82 & 9.76 & 13.27 & 4.99 \\
\hline $05976 \mathrm{~F}$ & bi-fuel & 1045.00 & 8.20 & 82.20 & 6.67 & 40.06 & \begin{tabular}{|c|}
68.64 \\
\end{tabular} & 46.72 & 11.56 & 15.22 & 4.47 \\
\hline $05992 \mathrm{~F}$ & bi-fuel & 902.00 & 0.00 & 99.00 & 0.00 & 48.24 & 72.79 & 48.24 & 9.11 & 12.39 & 5.35 \\
\hline 05994F & bi-fuel & 1407.00 & 12.00 & 117.30 & 9.76 & 57.16 & 98.25 & 66.92 & 10.88 & 14.32 & 4.76 \\
\hline $05995 \mathrm{~F}$ & bi-fuel & 1816.00 & 0.00 & 122.00 & 0.00 & 59.45 & 89.71 & 59.45 & 14.89 & 20.24 & 3.27 \\
\hline 05996F & bi-fuel & 1491.00 & 22.00 & 109.00 & 17.89 & 53.12 & 102.15 & 71.00 & 11.38 & 14.60 & 4.76 \\
\hline 05997F & bi-fuel & 986.00 & 0.00 & 88.10 & 0.00 & 42.93 & 64.78 & 42.93 & 11.19 & 15.22 & 4.35 \\
\hline UT & gasoline & 2915.00 & 181.00 & & \begin{tabular}{l|l}
147.15 \\
\end{tabular} & & 181.00 & 147.15 & 16.10 & 16.10 & 5.05 \\
\hline
\end{tabular}


Table A.1. Monthly Fuel Use Data from Vehicle Operation Log Forms

\begin{tabular}{|c|c|c|c|c|c|c|c|c|c|c|c|}
\hline \multicolumn{12}{|c|}{ February-98 } \\
\hline $\begin{array}{l}\text { TxDOT Eqpt. } \\
\text { No. }\end{array}$ & type & miles this mo. & $\begin{array}{c}\text { gasoline used } \\
\text { (gallons) }\end{array}$ & $\begin{array}{c}\text { LPG used (act. } \\
\text { gallons) }\end{array}$ & $\begin{array}{c}\text { gasoline cost } \\
(\$)\end{array}$ & LPG $\operatorname{cost}(\$)$ & $\begin{array}{l}\text { tot. equiv } \\
\text { gallons }\end{array}$ & $\begin{array}{l}\text { total fuel cost } \\
(\$)\end{array}$ & mi/act. gallon & MPEGG & $\begin{array}{c}\text { FOC } \\
\text { (cents/mile) }\end{array}$ \\
\hline $03556 \mathrm{G}$ & bi-fuel & 1715.00 & 0.00 & 179.00 & 0.00 & 108.31 & 131.62 & 108.31 & 9.58 & 13.03 & 6.32 \\
\hline 03558G & bi-fuel & 3083.00 & 18.00 & 271.00 & 14.26 & 163.98 & 217.26 & 178.24 & 10.67 & 14.19 & 5.78 \\
\hline $03562 \mathrm{G}$ & bi-fuel & 2716.00 & 78.00 & 141.10 & 61.78 & 85.38 & 181.75 & 147.16 & 12.40 & 14.94 & 5.42 \\
\hline $03563 G$ & bi-fuel & 1158.00 & 0.00 & 120.00 & 0.00 & 72.61 & 88.24 & 72.61 & 9.65 & 13.12 & 6.27 \\
\hline 03570G & bi-fuel & 1396.00 & 6.00 & 84.60 & 4.75 & 51.19 & 68.21 & 55.94 & 15.41 & 20.47 & 4.01 \\
\hline 03574G & bi-fuel & 1103.00 & 0.00 & 101.00 & 0.00 & 61.12 & 74.26 & 61.12 & 10.92 & 14.85 & 5.54 \\
\hline $03575 \mathrm{G}$ & bi-fuel & 1212.00 & 18.00 & 91.40 & 14.26 & 55.31 & 85.21 & 69.56 & 11.08 & 14.22 & 5.74 \\
\hline $03577 \mathrm{G}$ & bi-fuel & 780.00 & 50.00 & 40.00 & 39.61 & 24.20 & 79.41 & 63.81 & 8.67 & 9.82 & 8.18 \\
\hline 03578G & bi-fuel & 785.00 & 18.00 & 71.10 & 14.26 & 43.02 & 70.28 & 57.28 & 8.81 & 11.17 & 7.30 \\
\hline 03579G & bi-fuel & & & & & & & & & & \\
\hline 03625G & bi-fuel & & & & & & & & & & \\
\hline $03626 \mathrm{G}$ & bi-fuel & 4377.00 & 0.00 & 380.00 & 0.00 & 229.94 & 279.41 & 229.94 & 11.52 & 15.67 & 5.25 \\
\hline $04355 \mathrm{G}$ & gasoline & & & & & & & & & & \\
\hline $05414 \mathrm{~F}$ & bi-fuel & & & & & & & & & & \\
\hline $05415 \mathrm{~F}$ & bi-fuel & & & & & & & & & & \\
\hline $05418 \mathrm{~F}$ & bi-fuel & & & & & & & & & & \\
\hline $05419 \mathrm{~F}$ & bi-fuel & 2095.00 & 0.00 & 82.50 & 0.00 & 49.92 & 60.66 & 49.92 & 25.39 & 34.54 & 2.38 \\
\hline $03644 \mathrm{G}$ & bi-fuel & 913.00 & 0.00 & 72.00 & 0.00 & 34.76 & 52.94 & 34.76 & 12.68 & 17.25 & 3.81 \\
\hline 03649G & bi-fuel & 768.00 & 0.00 & 71.70 & 0.00 & 34.62 & 52.72 & 34.62 & 10.71 & 14.57 & 4.51 \\
\hline $03651 \mathrm{G}$ & bi-fuel & 899.00 & 6.00 & 41.40 & 4.75 & 19.99 & 36.44 & 24.74 & 18.97 & 24.67 & 2.75 \\
\hline $03652 \mathrm{G}$ & bi-fuel & 926.00 & 0.00 & 92.00 & 0.00 & 44.42 & 67.65 & 44.42 & 10.07 & 13.69 & 4.80 \\
\hline $03655 \mathrm{G}$ & bi-fuel & 220.00 & 0.00 & 21.00 & 0.00 & 10.14 & 15.44 & 10.14 & 10.48 & 14.25 & 4.61 \\
\hline $04353 G$ & gasoline & 1393.00 & 121.60 & & 96.32 & & 121.60 & 96.32 & 11.46 & 11.46 & 6.91 \\
\hline $04354 \mathrm{G}$ & gasoline & 988.00 & 64.90 & & 51.41 & & 64.90 & 51.41 & 15.22 & 15.22 & 5.20 \\
\hline $05971 \mathrm{~F}$ & bi-fuel & 407.00 & 0.00 & 20.00 & 0.00 & 9.66 & 14.71 & 9.66 & 20.35 & 27.68 & 2.37 \\
\hline 05972F & bi-fuel & 446.00 & 27.70 & 19.40 & 21.94 & 9.37 & 41.96 & 31.31 & 9.47 & 10.63 & 7.02 \\
\hline $05974 \mathrm{~F}$ & bi-fuel & 1544.00 & 16.00 & 108.00 & 12.67 & 52.14 & 95.41 & 64.82 & 12.45 & 16.18 & 4.20 \\
\hline $05975 \mathrm{~F}$ & bi-fuel & 1964.00 & 7.00 & 188.00 & 5.54 & 90.77 & 145.24 & 96.31 & 10.07 & 13.52 & 4.90 \\
\hline $05976 \mathrm{~F}$ & bi-fuel & 1415.00 & 0.00 & 136.80 & 0.00 & 66.05 & 100.59 & 66.05 & 10.34 & 14.07 & 4.67 \\
\hline $05992 \mathrm{~F}$ & bi-fuel & 1142.00 & 7.00 & 82.10 & 5.54 & 39.64 & 67.37 & 45.18 & 12.82 & 16.95 & 3.96 \\
\hline $05994 \mathrm{~F}$ & bi-fuel & 1764.00 & 10.00 & 160.90 & 7.92 & 77.68 & 128.31 & 85.60 & 10.32 & 13.75 & 4.85 \\
\hline $05995 \mathrm{~F}$ & bi-fuel & 1446.00 & 0.00 & 159.00 & 0.00 & 76.77 & 116.91 & 76.77 & 9.09 & 12.37 & 5.31 \\
\hline 05996F & bi-fuel & 1357.00 & 0.00 & 172.00 & 0.00 & 83.04 & 126.47 & 83.04 & 7.89 & 10.73 & 6.12 \\
\hline 05997F & bi-fuel & 555.00 & 0.00 & 48.20 & 0.00 & 23.27 & 35.44 & 23.27 & 11.51 & 15.66 & 4.19 \\
\hline UT & gasoline & 1427.00 & 94.60 & & 74.93 & & 94.60 & 74.93 & 15.08 & 15.08 & 5.25 \\
\hline
\end{tabular}


Table A.1. Monthly Fuel Use Data from Vehicle Operation Log Forms

\begin{tabular}{|c|c|c|c|c|c|c|c|c|c|c|c|}
\hline \multicolumn{12}{|c|}{ March-98 } \\
\hline $\begin{array}{l}\text { TxDOT Eqpt. } \\
\text { No. }\end{array}$ & type & miles this mo. & $\begin{array}{c}\text { gasoline used } \\
\text { (gallons) }\end{array}$ & $\begin{array}{c}\text { LPG used (act. } \\
\text { gallons) }\end{array}$ & $\begin{array}{c}\text { gasoline cost } \\
(\$)\end{array}$ & LPG $\operatorname{cost}(\$)$ & $\begin{array}{l}\text { tot. equiv } \\
\text { gallons }\end{array}$ & $\begin{array}{l}\text { total fuel cost } \\
(\$)\end{array}$ & mi/act. gallon & MPEGG & $\begin{array}{c}\text { FOC } \\
\text { (cents/mile) }\end{array}$ \\
\hline $03556 \mathrm{G}$ & bi-fuel & 1833.00 & 38.00 & 126.00 & 29.13 & 73.34 & 130.65 & 102.48 & 11.18 & 14.03 & $5.5 \mathrm{~s}$ \\
\hline 03558G & bi-fuel & & 0.00 & 47.00 & 0.00 & 27.36 & 34.56 & 27.36 & & & \\
\hline $03562 \mathrm{G}$ & bi-fuel & 1300.00 & 21.00 & 88.50 & 16.10 & 51.52 & 86.07 & 67.61 & 11.87 & 15.10 & 5.20 \\
\hline $03563 G$ & bi-fuel & 968.00 & 0.00 & 44.00 & 0.00 & 25.61 & 32.35 & 25.61 & 22.00 & 29.92 & 2.65 \\
\hline 03570G & bi-fuel & 26.00 & & & & & & & & & \\
\hline 03574G & bi-fuel & 1769.00 & 89.00 & 43.40 & 68.23 & 25.26 & 120.91 & 93.49 & 13.36 & 14.63 & 5.28 \\
\hline $03575 \mathrm{G}$ & bi-fuel & 1055.00 & 0.00 & 92.10 & 0.00 & 53.61 & 67.72 & 53.61 & 11.45 & 15.58 & 5.08 \\
\hline $03577 \mathrm{G}$ & bi-fuel & 1470.00 & 71.00 & 128.00 & 54.43 & 74.51 & 165.12 & 128.94 & 7.39 & 8.90 & 8.77 \\
\hline 03578G & bi-fuel & 792.00 & 0.00 & 106.20 & 0.00 & 61.82 & 78.09 & 61.82 & 7.46 & 10.14 & 7.81 \\
\hline 03579G & bi-fuel & & & & & & & & & & \\
\hline 03625G & bi-fuel & & & & & & & & & & \\
\hline $03626 \mathrm{G}$ & bi-fuel & 4837.00 & 0.00 & 432.00 & 0.00 & 251.47 & 317.65 & 251.47 & 11.20 & 15.23 & 5.20 \\
\hline $04355 \mathrm{G}$ & gasoline & & & & & & & & & & \\
\hline $05414 \mathrm{~F}$ & bi-fuel & & & & & & & & & & \\
\hline $05415 \mathrm{~F}$ & bi-fuel & 991.00 & 52.00 & 42.00 & 39.86 & 24.45 & 82.88 & 64.31 & 10.54 & 11.96 & $6.4 \mathrm{~s}$ \\
\hline $05418 \mathrm{~F}$ & bi-fuel & & & & & & & & & & \\
\hline $05419 \mathrm{~F}$ & bi-fuel & 2149.00 & 0.00 & 149.80 & 0.00 & 87.20 & 110.15 & 87.20 & 14.35 & 19.51 & 4.06 \\
\hline $03644 \mathrm{G}$ & bi-fuel & 741.00 & 17.00 & 79.00 & 13.03 & 36.32 & 75.09 & 49.36 & 7.72 & 9.87 & 6.66 \\
\hline 03649G & bi-fuel & 820.00 & 0.00 & 75.00 & 0.00 & 52.43 & 55.15 & 52.43 & 10.93 & 14.87 & 6.39 \\
\hline $03651 \mathrm{G}$ & bi-fuel & 476.00 & 8.00 & 43.40 & 6.13 & 30.34 & 39.91 & 36.47 & 9.26 & 11.93 & 7.66 \\
\hline $03652 \mathrm{G}$ & bi-fuel & 637.00 & 0.00 & 44.00 & 0.00 & 30.76 & 32.35 & 30.76 & 14.48 & 19.69 & 4.83 \\
\hline $03655 \mathrm{G}$ & bi-fuel & 268.00 & 9.10 & 21.00 & 6.98 & 14.68 & 24.54 & 21.66 & 8.90 & 10.92 & 8.08 \\
\hline $04353 G$ & gasoline & 2006.00 & 143.70 & & 110.16 & & 143.70 & 110.16 & 13.96 & 13.96 & 5.49 \\
\hline 04354G & gasoline & 897.00 & 51.60 & & 39.56 & & 51.60 & 39.56 & 17.38 & 17.38 & 4.41 \\
\hline $05971 \mathrm{~F}$ & bi-fuel & 887.00 & 36.00 & 61.50 & 27.60 & 42.99 & 81.22 & 70.59 & 9.10 & 10.92 & 7.96 \\
\hline 05972F & bi-fuel & 511.00 & 35.20 & 0.00 & 26.98 & 0.00 & 35.20 & 26.98 & 14.52 & 14.52 & 5.28 \\
\hline $05974 \mathrm{~F}$ & bi-fuel & 1062.00 & 16.70 & 82.00 & 12.80 & 57.32 & 76.99 & 70.12 & 10.76 & 13.79 & 6.60 \\
\hline $05975 \mathrm{~F}$ & bi-fuel & 906.00 & 0.00 & 56.00 & 0.00 & 39.14 & 41.18 & 39.14 & 16.18 & 22.00 & 4.32 \\
\hline $05976 \mathrm{~F}$ & bi-fuel & 1348.00 & 0.00 & 132.20 & 0.00 & 92.41 & 97.21 & 92.41 & 10.20 & 13.87 & 6.86 \\
\hline $05992 \mathrm{~F}$ & bi-fuel & 971.00 & 0.00 & 110.30 & 0.00 & 77.10 & 81.10 & 77.10 & 8.80 & 11.97 & 7.94 \\
\hline $05994 \mathrm{~F}$ & bi-fuel & 1362.00 & 8.30 & 113.40 & 6.36 & 79.27 & 91.68 & 85.63 & 11.19 & 14.86 & 6.29 \\
\hline $05995 \mathrm{~F}$ & bi-fuel & 938.00 & 12.00 & 118.00 & 9.20 & 82.48 & 98.76 & 91.68 & 7.22 & 9.50 & 9.77 \\
\hline 05996F & bi-fuel & 989.00 & 0.00 & 71.00 & 0.00 & 49.63 & 52.21 & 49.63 & 13.93 & 18.94 & 5.02 \\
\hline 05997F & bi-fuel & 1275.00 & 0.00 & 136.60 & 0.00 & 95.48 & 100.44 & 95.48 & \begin{tabular}{|l|}
9.33 \\
\end{tabular} & 12.69 & 7.49 \\
\hline UT & gasoline & 1889.00 & 81.60 & & 62.55 & & 81.60 & 62.55 & 23.15 & 23.15 & 3.31 \\
\hline
\end{tabular}


Table A.1. Monthly Fuel Use Data from Vehicle Operation Log Forms

\begin{tabular}{|c|c|c|c|c|c|c|c|c|c|c|c|}
\hline \multicolumn{12}{|c|}{ April-98 } \\
\hline $\begin{array}{l}\text { TXDOT Eqpt. } \\
\text { No. }\end{array}$ & type & miles this mo. & $\begin{array}{l}\text { gasoline used } \\
\text { (gallons) }\end{array}$ & $\begin{array}{c}\text { LPG used (act. } \\
\text { gallons) }\end{array}$ & $\begin{array}{c}\text { gasoline cost } \\
(\$)\end{array}$ & LPG $\operatorname{cost}(\$)$ & $\begin{array}{l}\text { tot. equiv } \\
\text { gallons }\end{array}$ & $\begin{array}{l}\text { total fuel cost } \\
\text { (\$) }\end{array}$ & mi/act. gallon & MPEGG & $\begin{array}{c}\mathrm{FOC} \\
\text { (cents/mile) }\end{array}$ \\
\hline $03556 \mathrm{G}$ & bi-fuel & 2168.00 & 18.00 & 205.00 & 13.33 & 122.59 & 168.74 & 135.92 & 9.72 & 12.85 & 6.27 \\
\hline $03558 \mathrm{G}$ & bi-fuel & & & & & & & & & & \\
\hline $03562 \mathrm{G}$ & bi-fuel & 3508.00 & 116.00 & 130.90 & 85.89 & 78.28 & 212.25 & 164.16 & 14.21 & 16.53 & 4.68 \\
\hline $03563 G$ & bi-fuel & 544.00 & 0.00 & 47.00 & 0.00 & 28.11 & 34.56 & 28.11 & 11.57 & 15.74 & 5.17 \\
\hline $03570 \mathrm{G}$ & bi-fuel & 3468.00 & 18.00 & 307.80 & 13.33 & 184.06 & 244.32 & 197.39 & 10.64 & 14.19 & 5.69 \\
\hline $03574 G$ & bi-fuel & 2926.00 & 11.10 & 42.00 & 8.22 & 25.12 & 41.98 & 33.33 & 55.10 & 69.70 & 1.14 \\
\hline 03575G & bi-fuel & 1638.00 & 13.00 & 139.50 & 9.63 & 83.42 & 115.57 & 93.05 & 10.74 & 14.17 & 5.68 \\
\hline $03577 \mathrm{G}$ & bi-fuel & 1334.00 & 64.00 & 92.00 & 47.39 & 55.02 & 131.65 & 102.40 & 8.55 & 10.13 & 7.68 \\
\hline $03578 \mathrm{G}$ & bi-fuel & 867.00 & 16.00 & 104.20 & 11.85 & 62.31 & 92.62 & \begin{tabular}{ll|}
74.16 \\
\end{tabular} & 7.21 & 9.36 & 8.55 \\
\hline $03579 \mathrm{G}$ & bi-fuel & & & & & & & & & & \\
\hline $03625 G$ & bi-fuel & & & & & & & & & & \\
\hline $03626 \mathrm{G}$ & bi-fuel & 4195.00 & 0.00 & 337.00 & 0.00 & 201.53 & 247.79 & 201.53 & 12.45 & 16.93 & 4.80 \\
\hline $04355 \mathrm{G}$ & gasoline & & & & & & & & & & \\
\hline $05414 \mathrm{~F}$ & bi-fuel & & & & & & & & & & \\
\hline $05415 \mathrm{~F}$ & bi-fuel & 1416.00 & 87.00 & 40.00 & 64.41 & 23.92 & 116.41 & 88.33 & 11.15 & 12.16 & 6.24 \\
\hline $05418 \mathrm{~F}$ & bi-fuel & & & & & & & & & & \\
\hline $05419 \mathrm{~F}$ & bi-fuel & 2637.00 & 8.00 & 188.30 & 5.92 & 112.60 & 146.46 & 118.53 & 13.43 & 18.01 & 4.49 \\
\hline $03644 \mathrm{G}$ & bi-fuel & 750.00 & 26.00 & 26.00 & \begin{tabular}{l|}
19.25 \\
\end{tabular} & 12.37 & 45.12 & 31.62 & \begin{tabular}{l|}
14.42 \\
\end{tabular} & 16.62 & 4.22 \\
\hline $03649 \mathrm{G}$ & bi-fuel & 909.00 & 22.20 & 21.00 & 16.44 & 9.99 & 37.64 & 26.43 & 21.04 & 24.15 & 2.91 \\
\hline $03651 \mathrm{G}$ & bi-fuel & 1225.00 & 32.00 & 102.40 & 23.69 & 48.71 & 107.29 & 72.40 & 9.11 & 11.42 & 5.91 \\
\hline $03652 \mathrm{G}$ & bi-fuel & 860.00 & 0.00 & 63.00 & 0.00 & 29.97 & 46.32 & 29.97 & 13.65 & 18.57 & 3.48 \\
\hline $03655 \mathrm{G}$ & bi-fuel & 150.00 & 19.40 & 0.00 & 14.36 & 0.00 & 19.40 & 14.36 & 7.73 & 7.73 & 9.58 \\
\hline $04353 G$ & gasoline & 1035.00 & 68.00 & & 50.35 & & 68.00 & 50.35 & 15.22 & 15.22 & 4.86 \\
\hline $04354 G$ & gasoline & 916.00 & 33.50 & & 24.80 & & 33.50 & 24.80 & 27.34 & 27.34 & 2.71 \\
\hline $05971 \mathrm{~F}$ & bi-fuel & 1445.00 & 34.00 & 133.50 & 25.17 & 63.51 & 132.16 & 88.68 & 8.63 & 10.93 & 6.14 \\
\hline $05972 \mathrm{~F}$ & bi-fuel & 539.00 & 13.30 & 0.00 & 9.85 & 0.00 & 13.30 & 9.85 & 40.53 & 40.53 & 1.83 \\
\hline $05974 \mathrm{~F}$ & bi-fuel & & & & & & & & & & \\
\hline $05975 \mathrm{~F}$ & bi-fuel & 1551.00 & 74.00 & 15.00 & 54.79 & 7.14 & 85.03 & 61.93 & 17.43 & 18.24 & 3.99 \\
\hline $05976 \mathrm{~F}$ & bi-fuel & 528.00 & 35.00 & 40.00 & 25.91 & 19.03 & 64.41 & 44.94 & 7.04 & 8.20 & 8.51 \\
\hline $05992 \mathrm{~F}$ & bi-fuel & 1389.00 & 0.00 & 146.60 & 0.00 & 69.74 & 107.79 & 69.74 & \begin{tabular}{|c|}
9.47 \\
\end{tabular} & 12.89 & 5.02 \\
\hline $05994 \mathrm{~F}$ & bi-fuel & 1214.00 & 67.00 & 85.50 & 49.61 & 40.67 & 129.87 & 90.28 & 7.96 & 9.35 & 7.44 \\
\hline $05995 \mathrm{~F}$ & bi-fuel & 1873.00 & 30.00 & 162.00 & 22.21 & 77.06 & $\begin{array}{ll}149.12 \\
\end{array}$ & 99.28 & 9.76 & 12.56 & 5.30 \\
\hline 05996F & bi-fuel & 282.00 & 12.00 & 18.00 & 8.88 & 8.56 & 25.24 & 17.45 & 9.40 & 11.17 & 6.19 \\
\hline $05997 \mathrm{~F}$ & bi-fuel & 2300.00 & 112.40 & 90.60 & 83.22 & 43.10 & \begin{tabular}{ll|}
179.02 \\
\end{tabular} & 126.32 & 11.33 & 12.85 & 5.49 \\
\hline \begin{tabular}{|l} 
UT \\
\end{tabular} & gasoline & 1635.00 & 90.10 & & 66.71 & & 90.10 & $\begin{array}{l}66.71 \\
\end{array}$ & \begin{tabular}{ll|}
18.15 \\
\end{tabular} & 18.15 & 4.08 \\
\hline
\end{tabular}


Table A.1. Monthly Fuel Use Data from Vehicle Operation Log Forms

\begin{tabular}{|c|c|c|c|c|c|c|c|c|c|c|c|}
\hline \multicolumn{12}{|c|}{ May-98 } \\
\hline $\begin{array}{l}\text { TxDOT Eqpt. } \\
\text { No. }\end{array}$ & type & miles this mo. & $\begin{array}{c}\text { gasoline used } \\
\text { (gallons) }\end{array}$ & $\begin{array}{c}\text { LPG used (act. } \\
\text { gallons) }\end{array}$ & $\begin{array}{c}\text { gasoline cost } \\
(\$)\end{array}$ & LPG $\operatorname{cost}(\$)$ & $\begin{array}{l}\text { tot. equiv } \\
\text { gallons }\end{array}$ & $\begin{array}{l}\text { total fuel cost } \\
(\$)\end{array}$ & mi/act. gallon & MPEGG & $\begin{array}{c}\text { FOC } \\
\text { (cents/mile) }\end{array}$ \\
\hline 03556G & bi-fuel & 1898.00 & & 184.20 & 0.00 & 107.15 & 135.44 & 107.15 & 10.30 & 14.01 & 5.65 \\
\hline 03558G & bi-fuel & & & 113.70 & 0.00 & 66.14 & 83.60 & 66.14 & & & \\
\hline $03562 \mathrm{G}$ & bi-fuel & 2524.00 & 65.00 & 97.10 & 48.37 & 56.48 & 136.40 & 104.86 & 15.57 & 18.50 & 4.15 \\
\hline $03563 G$ & bi-fuel & & & & 0.00 & 0.00 & 0.00 & 0.00 & & & \\
\hline 03570G & bi-fuel & & & & 0.00 & 0.00 & 0.00 & 0.00 & & & \\
\hline 03574G & bi-fuel & 1447.00 & 67.80 & 33.50 & 50.46 & 19.49 & 92.43 & 69.94 & 14.28 & 15.65 & 4.83 \\
\hline $03575 \mathrm{G}$ & bi-fuel & 1158.00 & & 111.80 & 0.00 & 65.03 & 82.21 & 65.03 & 10.36 & 14.09 & 5.62 \\
\hline $03577 \mathrm{G}$ & bi-fuel & 1216.00 & 65.00 & 123.00 & 48.37 & 71.55 & 155.44 & 119.92 & 6.47 & 7.82 & 9.86 \\
\hline 03578G & bi-fuel & 575.00 & & 91.29 & 0.00 & 53.10 & 67.13 & 53.10 & 6.30 & 8.57 & 9.24 \\
\hline 03579G & bi-fuel & & & & & & & & & & \\
\hline 03625G & bi-fuel & & & & & & & & & & \\
\hline $03626 \mathrm{G}$ & bi-fuel & 4602.00 & & 368.00 & 0.00 & 214.07 & 270.59 & 214.07 & 12.51 & 17.01 & 4.65 \\
\hline $04355 \mathrm{G}$ & gasoline & & & & & & & & & & \\
\hline $05414 \mathrm{~F}$ & bi-fuel & & & & & & & & & & \\
\hline $05415 \mathrm{~F}$ & bi-fuel & & 9.00 & 40.00 & 6.70 & 23.27 & 38.41 & 29.97 & & & \\
\hline $05418 \mathrm{~F}$ & bi-fuel & & & & 0.00 & 0.00 & 0.00 & 0.00 & & & \\
\hline $05419 \mathrm{~F}$ & bi-fuel & 2952.70 & 42.00 & 218.70 & 31.26 & 127.22 & 202.81 & 158.47 & 11.33 & 14.56 & 5.37 \\
\hline $03644 \mathrm{G}$ & bi-fuel & & & & & & & & & & \\
\hline 03649G & bi-fuel & 948.00 & 11.00 & 106.00 & 8.19 & 48.70 & 88.94 & 56.88 & 8.10 & 10.66 & 6.00 \\
\hline $03651 \mathrm{G}$ & bi-fuel & 1340.00 & 13.00 & 101.00 & 9.67 & 46.40 & 87.26 & 56.07 & 11.75 & 15.36 & 4.18 \\
\hline $03652 \mathrm{G}$ & bi-fuel & 710.00 & & 70.00 & 0.00 & 32.16 & 51.47 & 32.16 & 10.14 & 13.79 & 4.53 \\
\hline $03655 \mathrm{G}$ & bi-fuel & 311.00 & 19.50 & & 14.51 & 0.00 & 19.50 & 14.51 & 15.95 & 15.95 & 4.67 \\
\hline $04353 G$ & gasoline & 1698.00 & 118.60 & & 88.26 & & 118.60 & 88.26 & 14.32 & 14.32 & 5.20 \\
\hline 04354G & gasoline & 906.00 & 68.50 & & 50.98 & & 68.50 & 50.98 & 13.23 & 13.23 & 5.63 \\
\hline $05971 \mathrm{~F}$ & bi-fuel & 708.00 & 15.00 & 78.00 & 11.16 & 35.83 & 72.35 & 47.00 & 7.61 & 9.79 & 6.64 \\
\hline 05972F & bi-fuel & & & & & & & & & & \\
\hline $05974 \mathrm{~F}$ & bi-fuel & 2200.00 & & 187.00 & 0.00 & 85.91 & 137.50 & 85.91 & 11.76 & 16.00 & 3.90 \\
\hline $05975 \mathrm{~F}$ & bi-fuel & 1698.00 & 16.00 & 163.00 & 11.91 & 74.88 & 135.85 & 86.79 & 9.49 & 12.50 & 5.11 \\
\hline $05976 \mathrm{~F}$ & bi-fuel & 1012.00 & & 109.00 & 0.00 & 50.07 & 80.15 & 50.07 & 9.28 & 12.63 & 4.95 \\
\hline $05992 \mathrm{~F}$ & bi-fuel & 1171.00 & 18.00 & 104.70 & 13.40 & 48.10 & 94.99 & 61.49 & 9.54 & 12.33 & 5.25 \\
\hline $05994 \mathrm{~F}$ & bi-fuel & 446.00 & 11.00 & & 8.19 & 0.00 & 11.00 & 8.19 & 40.55 & 40.55 & 1.84 \\
\hline $05995 \mathrm{~F}$ & bi-fuel & 1748.00 & 14.00 & 175.00 & 10.42 & 80.40 & 142.68 & 90.81 & 9.25 & 12.25 & 5.20 \\
\hline 05996F & bi-fuel & 487.00 & & 38.70 & 0.00 & 17.78 & 28.46 & 17.78 & 12.58 & 17.11 & 3.65 \\
\hline 05997F & bi-fuel & 760.00 & 14.00 & 96.90 & 10.42 & 44.52 & 85.25 & 54.93 & 6.85 & 8.91 & 7.23 \\
\hline UT & gasoline & 2849.00 & 263.32 & & \begin{tabular}{l|l}
195.96 \\
\end{tabular} & & \begin{tabular}{l|l}
263.32 \\
\end{tabular} & 195.96 & 10.82 & 10.82 & 6.88 \\
\hline
\end{tabular}


Table A.1. Monthly Fuel Use Data from Vehicle Operation Log Forms

\begin{tabular}{|c|c|c|c|c|c|c|c|c|c|c|c|}
\hline \multicolumn{12}{|c|}{ June-98 } \\
\hline $\begin{array}{l}\text { TxDOT Eqpt. } \\
\text { No. }\end{array}$ & type & miles this mo. & $\begin{array}{c}\text { gasoline used } \\
\text { (gallons) }\end{array}$ & $\begin{array}{c}\text { LPG used (act. } \\
\text { gallons) }\end{array}$ & $\begin{array}{c}\text { gasoline cost } \\
(\$)\end{array}$ & LPG $\operatorname{cost}(\$)$ & $\begin{array}{l}\text { tot. equiv } \\
\text { gallons }\end{array}$ & $\begin{array}{l}\text { total fuel cost } \\
(\$)\end{array}$ & mi/act. gallon & MPEGG & $\begin{array}{c}\text { FOC } \\
\text { (cents/mile) }\end{array}$ \\
\hline 03556G & bi-fuel & 1658.00 & 7.00 & 184.10 & 5.25 & 101.60 & 142.37 & 106.85 & 8.68 & 11.65 & 6.44 \\
\hline 03558G & bi-fuel & & 0.00 & 111.00 & 0.00 & 61.26 & 81.62 & 61.26 & & & \\
\hline $03562 \mathrm{G}$ & bi-fuel & & & & & & & & & & \\
\hline $03563 G$ & bi-fuel & & & & & & & & & & \\
\hline O3570G & bi-fuel & & & & & & & & & & \\
\hline 03574G & bi-fuel & 2691.00 & 64.70 & 35.00 & 48.49 & 19.32 & 90.44 & 67.81 & 26.99 & 29.76 & 2.52 \\
\hline 03575G & bi-fuel & 2075.00 & 27.00 & 129.70 & 20.24 & 71.58 & 122.37 & 91.82 & 13.24 & 16.96 & 4.42 \\
\hline $03577 \mathrm{G}$ & bi-fuel & 1473.00 & 62.00 & 120.00 & 46.47 & 66.23 & 150.24 & 112.70 & 8.09 & 9.80 & 7.65 \\
\hline 03578G & bi-fuel & & & & & & & & & & \\
\hline 03579G & bi-fuel & & & & & & & & & & \\
\hline 03625G & bi-fuel & & & & & & & & & & \\
\hline $03626 \mathrm{G}$ & bi-fuel & 3424.00 & 0.00 & 328.00 & 0.00 & 181.02 & 241.18 & 181.02 & 10.44 & 14.20 & 5.20 \\
\hline $04355 \mathrm{G}$ & gasoline & & & & & & & & & & \\
\hline $05414 \mathrm{~F}$ & bi-fuel & & & & & & & & & & \\
\hline $05415 \mathrm{~F}$ & bi-fuel & & & & & & & & & & \\
\hline $05418 \mathrm{~F}$ & bi-fuel & 124.00 & 12.00 & & 8.99 & 0.00 & 12.00 & 8.99 & 10.33 & 10.33 & 7.25 \\
\hline $05419 \mathrm{~F}$ & bi-fuel & 2057.00 & 37.00 & 187.90 & 27.73 & 103.70 & 175.16 & 131.43 & 9.15 & 11.74 & 6.39 \\
\hline $03644 \mathrm{G}$ & bi-fuel & 564.00 & 18.00 & 66.00 & 13.49 & 28.35 & 66.53 & 41.84 & 6.71 & 8.48 & 7.42 \\
\hline 03649G & bi-fuel & 852.00 & 0.00 & 74.00 & 0.00 & 31.79 & 54.41 & 31.79 & 11.51 & 15.66 & 3.73 \\
\hline $03651 \mathrm{G}$ & bi-fuel & 1572.00 & 45.00 & 102.20 & 33.73 & 43.91 & 120.15 & 77.63 & 10.68 & 13.08 & 4.94 \\
\hline $03652 \mathrm{G}$ & bi-fuel & 949.00 & 11.00 & 44.00 & 8.24 & 18.90 & 43.35 & 27.15 & 17.25 & 21.89 & 2.86 \\
\hline $03655 \mathrm{G}$ & bi-fuel & 285.00 & 9.80 & 0.00 & 7.35 & 0.00 & 9.80 & 7.35 & 29.08 & 29.08 & 2.58 \\
\hline $04353 G$ & gasoline & 1662.00 & 114.00 & & 85.44 & & 114.00 & 85.44 & 14.58 & 14.58 & 5.14 \\
\hline 04354G & gasoline & 1079.00 & 83.40 & & 62.51 & & 83.40 & 62.51 & 12.94 & 12.94 & 5.79 \\
\hline $05971 \mathrm{~F}$ & bi-fuel & 553.00 & 19.00 & 58.00 & 14.24 & 24.92 & 61.65 & 39.16 & 7.18 & 8.97 & 7.08 \\
\hline $05972 \mathrm{~F}$ & bi-fuel & & & & & & & & & & \\
\hline $05974 \mathrm{~F}$ & bi-fuel & 1985.00 & 18.00 & 212.00 & 13.49 & 91.08 & 173.88 & 104.57 & 8.63 & 11.42 & 5.27 \\
\hline $05975 \mathrm{~F}$ & bi-fuel & 1414.00 & 14.00 & 190.00 & 10.49 & 81.62 & 153.71 & 92.12 & 6.93 & 9.20 & 6.51 \\
\hline $05976 \mathrm{~F}$ & bi-fuel & 1170.00 & 8.00 & 135.00 & 6.00 & 58.00 & 107.26 & 63.99 & 8.18 & 10.91 & 5.47 \\
\hline $05992 \mathrm{~F}$ & bi-fuel & 871.00 & 20.00 & 83.10 & 14.99 & 35.70 & 81.10 & 50.69 & 8.45 & 10.74 & 5.82 \\
\hline 05994F & bi-fuel & 1665.00 & 8.20 & 189.30 & 6.15 & 81.32 & 147.39 & 87.47 & 8.43 & 11.30 & 5.25 \\
\hline $05995 \mathrm{~F}$ & bi-fuel & 1266.00 & 2.00 & 174.00 & 1.50 & 74.75 & 129.94 & 76.25 & 7.19 & 9.74 & 6.02 \\
\hline 05996F & bi-fuel & 1751.00 & 0.00 & 179.90 & 0.00 & 77.29 & 132.28 & 77.29 & 9.73 & 13.24 & 4.41 \\
\hline 05997F & bi-fuel & 336.00 & 15.00 & 36.50 & 11.24 & 15.68 & 41.84 & 26.92 & 6.52 & 8.03 & 8.01 \\
\hline UT & gasoline & 7312.00 & 523.56 & & 392.41 & & 523.56 & 392.41 & 13.97 & 13.97 & 5.37 \\
\hline
\end{tabular}


Table A.1. Monthly Fuel Use Data from Vehicle Operation Log Forms

\begin{tabular}{|c|c|c|c|c|c|c|c|c|c|c|c|}
\hline \multicolumn{12}{|c|}{ July-98 } \\
\hline $\begin{array}{l}\text { TxDOT Eqpt. } \\
\text { No. }\end{array}$ & type & miles this mo. & $\begin{array}{c}\text { gasoline used } \\
\text { (gallons) }\end{array}$ & $\begin{array}{c}\text { LPG used (act. } \\
\text { gallons) }\end{array}$ & $\begin{array}{c}\text { gasoline cost } \\
(\$)\end{array}$ & LPG $\operatorname{cost}(\$)$ & $\begin{array}{l}\text { tot. equiv } \\
\text { gallons }\end{array}$ & $\begin{array}{l}\text { total fuel cost } \\
(\$)\end{array}$ & mi/act. gallon & MPEGG & $\begin{array}{c}\text { FOC } \\
\text { (cents/mile) }\end{array}$ \\
\hline $03556 \mathrm{G}$ & bi-fuel & 1327.00 & & & & & & & & & \\
\hline 03558G & bi-fuel & 1167.00 & 0.00 & 35.00 & 0.00 & 19.36 & 25.74 & 19.36 & 33.34 & 45.35 & 1.66 \\
\hline $03562 \mathrm{G}$ & bi-fuel & & 31.00 & 25.10 & 22.75 & 13.88 & 49.46 & 36.63 & & & \\
\hline $03563 G$ & bi-fuel & & & & & & & & & & \\
\hline O3570G & bi-fuel & & 12.00 & 47.00 & 8.81 & 26.00 & 46.56 & 34.80 & & & \\
\hline 03574G & bi-fuel & 2258.00 & 107.60 & 143.40 & 78.97 & 79.31 & 213.04 & 158.28 & 9.00 & 10.60 & 7.01 \\
\hline 03575G & bi-fuel & 496.00 & 7.00 & 44.00 & 5.14 & 24.34 & 39.35 & 29.47 & 9.73 & 12.60 & 5.94 \\
\hline $03577 \mathrm{G}$ & bi-fuel & 1356.00 & 91.00 & 71.00 & 66.78 & 39.27 & 143.21 & 106.06 & 8.37 & 9.47 & 7.82 \\
\hline 03578G & bi-fuel & 2634.00 & & 307.00 & 0.00 & 169.80 & 225.74 & 169.80 & 8.58 & 11.67 & 6.45 \\
\hline 03579G & bi-fuel & & & & & & & & & & \\
\hline 03625G & bi-fuel & & & & & & & & & & \\
\hline $03626 \mathrm{G}$ & bi-fuel & 4313.00 & 0.00 & 350.00 & 0.00 & 193.59 & 257.35 & 193.59 & 12.32 & 16.76 & 4.49 \\
\hline $04355 \mathrm{G}$ & gasoline & & & & & & & & & & \\
\hline $05414 \mathrm{~F}$ & bi-fuel & & & & & & & & & & \\
\hline $05415 \mathrm{~F}$ & bi-fuel & & & & & & & & & & \\
\hline $05418 \mathrm{~F}$ & bi-fuel & 1793.00 & & 75.10 & 0.00 & 41.54 & 55.22 & 41.54 & 23.87| & 32.47 & 2.32 \\
\hline $05419 \mathrm{~F}$ & bi-fuel & 3051.00 & 45.60 & 97.60 & 33.47 & 53.98 & 117.36 & 87.45 & 21.31 & 26.00 & 2.87 \\
\hline $03644 \mathrm{G}$ & bi-fuel & 771.00 & 0.00 & 92.00 & 0.00 & 39.63 & 67.65 & 39.63 & 8.38 & 11.40 & 5.14 \\
\hline 03649G & bi-fuel & 1402.00 & 8.00 & 135.00 & 5.87 & 58.16 & 107.26 & 64.03 & 9.80 & 13.07 & 4.57 \\
\hline $03651 \mathrm{G}$ & bi-fuel & 2071.00 & 10.00 & 227.30 & 7.34 & 97.92 & 177.13 & 105.26 & 8.73 & 11.69 & 5.08 \\
\hline $03652 \mathrm{G}$ & bi-fuel & 1407.00 & 7.00 & 148.00 & 5.14 & 63.76 & 115.82 & 68.90 & 9.08 & 12.15 & 4.90 \\
\hline $03655 \mathrm{G}$ & bi-fuel & 315.00 & 0.00 & 54.50 & 0.00 & 23.48 & 40.07 & 23.48 & 5.78 & 7.86 & 7.45 \\
\hline $04353 G$ & gasoline & 1153.00 & 94.00 & & 68.99 & & 94.00 & 68.99 & 12.27 & 12.27 & 5.98 \\
\hline $04354 \mathrm{G}$ & gasoline & 927.00 & 62.80 & & 46.09 & & 62.80 & 46.09 & 14.76 & 14.76 & 4.97 \\
\hline $05971 \mathrm{~F}$ & bi-fuel & 453.00 & 13.00 & 105.60 & 9.54 & 45.49 & 90.65 & 55.03 & 3.82 & 5.00 & 12.15 \\
\hline 05972F & bi-fuel & & 0.00 & 23.70 & 0.00 & 10.21 & 17.43 & 10.21 & 0.00 & & \\
\hline $05974 \mathrm{~F}$ & bi-fuel & 2041.00 & 0.00 & 203.00 & 0.00 & 87.45 & 149.26 & 87.45 & 10.05 & 13.67 & 4.28 \\
\hline $05975 \mathrm{~F}$ & bi-fuel & 1152.00 & 7.00 & 66.00 & 5.14 & 28.43 & 55.53 & 33.57 & 15.78 & 20.75 & 2.91 \\
\hline $05976 \mathrm{~F}$ & bi-fuel & 764.00 & 5.50 & 93.00 & 4.04 & 40.06 & 73.88 & 44.10 & \begin{tabular}{|c|}
7.76 \\
\end{tabular} & 10.34 & 5.77 \\
\hline $05992 \mathrm{~F}$ & bi-fuel & 2150.00 & 20.00 & 257.10 & 14.68 & 110.76 & 209.04 & 125.44 & 7.76 & 10.28 & 5.83 \\
\hline $05994 \mathrm{~F}$ & bi-fuel & 2680.00 & 0.00 & 232.60 & 0.00 & 100.20 & 171.03 & 100.20 & 11.52 & 15.67 & 3.74 \\
\hline $05995 \mathrm{~F}$ & bi-fuel & 721.00 & 0.00 & 86.00 & 0.00 & 37.05 & 63.24 & 37.05 & 8.38 & 11.40 & 5.14 \\
\hline 05996F & bi-fuel & 575.00 & 16.60 & 37.50 & 12.18 & 16.16 & 44.17 & 28.34 & 10.63 & 13.02 & 4.93 \\
\hline 05997F & bi-fuel & 2187.00 & 47.10 & 185.90 & 34.57 & 80.09 & 183.79 & 114.65 & 9.39 & 11.90 & 5.24 \\
\hline UT & gasoline & 1899.40 & 113.29 & & 83.15 & & 113.29 & \begin{tabular}{|l|}
83.15 \\
\end{tabular} & \begin{tabular}{|c|}
16.77 \\
\end{tabular} & 16.77 & 4.38 \\
\hline
\end{tabular}


Table A.1. Monthly Fuel Use Data from Vehicle Operation Log Forms

\begin{tabular}{|c|c|c|c|c|c|c|c|c|c|c|c|}
\hline \multicolumn{12}{|c|}{ August-98 } \\
\hline $\begin{array}{l}\text { TxDOT Eqpt. } \\
\text { No. }\end{array}$ & type & miles this mo. & $\begin{array}{c}\text { gasoline used } \\
\text { (gallons) }\end{array}$ & $\begin{array}{c}\text { LPG used (act. } \\
\text { gallons) }\end{array}$ & $\begin{array}{c}\text { gasoline cost } \\
(\$)\end{array}$ & LPG $\operatorname{cost}(\$)$ & $\begin{array}{l}\text { tot. equiv } \\
\text { gallons }\end{array}$ & $\begin{array}{l}\text { total fuel cost } \\
(\$)\end{array}$ & mi/act. gallon & MPEGG & $\begin{array}{c}\text { FOC } \\
\text { (cents/mile) }\end{array}$ \\
\hline $03556 \mathrm{G}$ & bi-fuel & & & & & & & & & & \\
\hline 03558G & bi-fuel & & & & & & & & & & \\
\hline $03562 \mathrm{G}$ & bi-fuel & 3483.00 & 124.00 & 118.20 & 87.46 & 64.84 & 210.91 & 152.30 & 14.38 & 16.51 & 4.37 \\
\hline $03563 G$ & bi-fuel & & & & & & & & & & \\
\hline 03570G & bi-fuel & 1261.00 & & & & & & & & & \\
\hline 03574G & bi-fuel & 2713.00 & 52.00 & 75.00 & 36.68 & 41.15 & 107.15 & 77.82 & 21.36 & 25.32 & 2.87 \\
\hline 03575G & bi-fuel & 2761.00 & & 302.20 & 0.00 & 165.79 & 222.21 & 165.79 & 9.14 & 12.43 & 6.00 \\
\hline $03577 \mathrm{G}$ & bi-fuel & 1291.00 & 44.00 & 123.00 & 31.03 & 67.48 & 134.44 & 98.51 & 7.73 & 9.60 & 7.63 \\
\hline 03578G & bi-fuel & 1585.00 & 108.00 & & 76.17 & 0.00 & 108.00 & 76.17 & 14.68 & 14.68 & 4.81 \\
\hline 03579G & bi-fuel & 913.00 & & 77.60 & 0.00 & 42.57 & 57.06 & 42.57 & 11.77 & 16.00 & 4.66 \\
\hline 03625G & bi-fuel & & & & & & & & & & \\
\hline $03626 \mathrm{G}$ & bi-fuel & 2112.00 & 0.00 & 223.00 & 0.00 & 122.34 & 163.97 & 122.34 & 9.47 & 12.88 & 5.79 \\
\hline $04355 \mathrm{G}$ & gasoline & & & & & & & & & & \\
\hline $05414 \mathrm{~F}$ & bi-fuel & 1137.00 & & 117.70 & 0.00 & 64.57 & 86.54 & 64.57 & 9.66 & 13.14 & 5.68 \\
\hline $05415 \mathrm{~F}$ & bi-fuel & 2222.00 & & 216.00 & 0.00 & 118.50 & 158.82 & 118.50 & 10.29 & 13.99 & 5.33 \\
\hline $05418 \mathrm{~F}$ & bi-fuel & 541.00 & 30.00 & 40.80 & 21.16 & 22.38 & 60.00 & 43.54 & 7.64 & 9.02 & 8.05 \\
\hline $05419 \mathrm{~F}$ & bi-fuel & 2281.00 & & 210.00 & 0.00 & 115.21 & 154.41 & 115.21 & 10.86 & 14.77 & 5.05 \\
\hline $03644 \mathrm{G}$ & bi-fuel & 1037.00 & 71.00 & 0.00 & 50.08 & 0.00 & 71.00 & 50.08 & 14.61 & 14.61 & 4.83 \\
\hline 03649G & bi-fuel & 1087.00 & 93.00 & 25.00 & 65.59 & 10.66 & 111.38 & 76.25 & 9.21 & 9.76 & 7.01 \\
\hline $03651 \mathrm{G}$ & bi-fuel & 2386.00 & 109.00 & 0.00 & 76.88 & 0.00 & 109.00 & 76.88 & 21.89 & 21.89 & 3.22 \\
\hline $03652 \mathrm{G}$ & bi-fuel & 1435.00 & 113.00 & 0.00 & 79.70 & 0.00 & 113.00 & 79.70 & 12.70 & 12.70 & 5.55 \\
\hline $03655 \mathrm{G}$ & bi-fuel & 310.00 & 41.80 & 0.00 & 29.48 & 0.00 & 41.80 & 29.48 & 7.42 & 7.42 & 9.51 \\
\hline $04353 G$ & gasoline & 1133.00 & 104.00 & & 73.35 & & 104.00 & 73.35 & 10.89 & 10.89 & 6.47 \\
\hline $04354 \mathrm{G}$ & gasoline & 1561.00 & 107.40 & & 75.75 & & 107.40 & 75.75 & 14.53 & 14.53 & 4.85 \\
\hline $05971 \mathrm{~F}$ & bi-fuel & 590.00 & 110.00 & 18.00 & 77.58 & 7.67 & 123.24 & 85.26 & 4.61 & 4.79 & 14.45 \\
\hline 05972F & bi-fuel & 316.00 & 17.30 & 0.00 & 12.20 & 0.00 & 17.30 & 12.20 & 18.27 & 18.27 & 3.86 \\
\hline $05974 \mathrm{~F}$ & bi-fuel & 1384.00 & 88.00 & 0.00 & 62.07 & 0.00 & 88.00 & 62.07 & 15.73 & 15.73 & 4.48 \\
\hline $05975 \mathrm{~F}$ & bi-fuel & 1513.00 & 14.00 & 199.00 & 9.87 & 84.83 & 160.32 & 94.71 & 7.10 & 9.44 & 6.26 \\
\hline $05976 \mathrm{~F}$ & bi-fuel & 1296.00 & 0.00 & 120.00 & 0.00 & 51.16 & 88.24 & 51.16 & 10.80 & 14.69 & 3.95 \\
\hline $05992 \mathrm{~F}$ & bi-fuel & 1690.00 & 20.00 & 0.00 & 14.11 & 0.00 & 20.00 & 14.11 & 84.50 & 84.50 & 0.83 \\
\hline $05994 \mathrm{~F}$ & bi-fuel & 1722.00 & 129.00 & 0.00 & 90.98 & 0.00 & 129.00 & 90.98 & 13.35 & 13.35 & 5.28 \\
\hline $05995 \mathrm{~F}$ & bi-fuel & 718.00 & 44.00 & 0.00 & 31.03 & 0.00 & 44.00 & 31.03 & 16.32 & 16.32 & 4.32 \\
\hline 05996F & bi-fuel & 1296.00 & 90.20 & 35.50 & 63.62 & 15.13 & 116.30 & 78.75 & 10.31 & 11.14 & 6.08 \\
\hline 05997F & bi-fuel & 1599.00 & 0.00 & 195.90 & 0.00 & 83.51 & 144.04 & 83.51 & 8.16 & 11.10 & 5.22 \\
\hline UT & gasoline & 1129.00 & 72.59 & & 51.20 & & 72.59 & 51.20 & 15.55 & 15.55 & 4.53 \\
\hline
\end{tabular}


Table A.1. Monthly Fuel Use Data from Vehicle Operation Log Forms

\begin{tabular}{|c|c|c|c|c|c|c|c|c|c|c|c|}
\hline \multicolumn{12}{|c|}{ September-98 } \\
\hline $\begin{array}{l}\text { TxDOT Eqpt. } \\
\text { No. }\end{array}$ & type & miles this mo. & $\begin{array}{c}\text { gasoline used } \\
\text { (gallons) }\end{array}$ & $\begin{array}{c}\text { LPG used (act. } \\
\text { gallons) }\end{array}$ & $\begin{array}{c}\text { gasoline cost } \\
(\$)\end{array}$ & LPG $\operatorname{cost}(\$)$ & $\begin{array}{l}\text { tot. equiv } \\
\text { gallons }\end{array}$ & $\begin{array}{l}\text { total fuel cost } \\
(\$)\end{array}$ & mi/act. gallon & MPEGG & $\begin{array}{c}\text { FOC } \\
\text { (cents/mile) }\end{array}$ \\
\hline 03556G & bi-fuel & 2472.00 & 13.00 & 258.20 & 8.61 & 143.53 & 202.85 & 152.15 & 9.12 & 12.19 & 6.15 \\
\hline 03558G & bi-fuel & & & & & & & & & & \\
\hline $03562 \mathrm{G}$ & bi-fuel & & & & & & & & & & \\
\hline $03563 G$ & bi-fuel & 3498.00 & 40.00 & 284.20 & 26.50 & 157.99 & 248.97 & 184.49 & 10.79 & 14.05 & 5.27 \\
\hline O3570G & bi-fuel & 1880.00 & 118.60 & & 78.57 & 0.00 & 118.60 & 78.57 & 15.85 & 15.85 & 4.18 \\
\hline 03574G & bi-fuel & 2834.00 & 101.70 & 124.60 & 67.38 & 69.27 & 193.32 & 136.64 & 12.52 & 14.66 & 4.82 \\
\hline $03575 \mathrm{G}$ & bi-fuel & 1378.00 & 99.00 & 15.00 & 65.59 & 8.34 & 110.03 & 73.93 & 12.09 & 12.52 & 5.36 \\
\hline $03577 \mathrm{G}$ & bi-fuel & 1261.00 & 49.00 & 82.00 & 32.46 & 45.58 & 109.29 & 78.05 & 9.63 & 11.54 & 6.19 \\
\hline 03578G & bi-fuel & & & & & & & & & & \\
\hline 03579G & bi-fuel & 1387.00 & 92.10 & & 61.02 & 0.00 & 92.10 & 61.02 & 15.06 & 15.06 & 4.40 \\
\hline $03625 G$ & bi-fuel & & & & & & & & & & \\
\hline $03626 \mathrm{G}$ & bi-fuel & & & & & & & & & & \\
\hline 04355G & gasoline & & & & & & & & & & \\
\hline $05414 \mathrm{~F}$ & bi-fuel & & & & & & & & & & \\
\hline $05415 \mathrm{~F}$ & bi-fuel & 2426.00 & 202.00 & & 133.83 & 0.00 & 202.00 & 133.83 & 12.01 & 12.01 & 5.52 \\
\hline $05418 \mathrm{~F}$ & bi-fuel & & & & & & & & & & \\
\hline 05419F & bi-fuel & 522.00 & & 36.60 & 0.00 & 20.35 & 26.91 & 20.35 & 14.26 & 19.40 & 3.90 \\
\hline $03644 \mathrm{G}$ & bi-fuel & 724.00 & 22.00 & 24.00 & 14.58 & 10.41 & 39.65 & 24.98 & 15.74 & 18.26 & 3.45 \\
\hline 03649G & bi-fuel & 685.00 & 16.00 & 87.00 & 10.60 & 37.72 & 79.97| & 48.32 & 6.65 & 8.57 & 7.05 \\
\hline $03651 \mathrm{G}$ & bi-fuel & 917.00 & 16.00 & 60.00 & 10.60 & 26.02 & 60.12 & 36.62 & 12.07 & 15.25 & 3.99 \\
\hline $03652 \mathrm{G}$ & bi-fuel & 1319.00 & 20.00 & 63.00 & 13.25 & 27.32 & 66.32 & 40.57 & 15.89 & 19.89 & 3.08 \\
\hline $03655 \mathrm{G}$ & bi-fuel & & & & & & & & & & \\
\hline 04353G & gasoline & & 49.00 & & 32.46 & & 49.00 & 32.46 & 0.00 & & \\
\hline $04354 \mathrm{G}$ & gasoline & 600.00 & 35.80 & & 23.72 & & 35.80 & 23.72 & 16.76 & 16.76 & 3.95 \\
\hline $05971 \mathrm{~F}$ & bi-fuel & 250.00 & 0.00 & 52.00 & 0.00 & 22.55 & 38.24 & 22.55 & 4.81 & 6.54 & 9.02 \\
\hline $05972 \mathrm{~F}$ & bi-fuel & 410.00 & 26.20 & 0.00 & 17.36 & 0.00 & 26.20 & 17.36 & 15.65 & 15.65 & 4.23 \\
\hline $05974 \mathrm{~F}$ & bi-fuel & 1487.00 & 14.00 & 134.00 & 9.28 & 58.10 & 112.53 & 67.38 & 10.05 & 13.21 & 4.53 \\
\hline $05975 \mathrm{~F}$ & bi-fuel & 358.00 & 0.00 & 83.00 & 0.00 & 35.99 & 61.03 & 35.99 & 4.31 & 5.87 & 10.05 \\
\hline $05976 \mathrm{~F}$ & bi-fuel & 935.00 & 7.50 & 134.00 & 4.97 & 58.10 & 106.03 & 63.07 & 6.61 & 8.82 & 6.75 \\
\hline $05992 \mathrm{~F}$ & bi-fuel & 1476.00 & 26.00 & 118.00 & 17.23 & 51.16 & 112.76 & 68.39 & 10.25 & 13.09 & 4.63 \\
\hline 05994F & bi-fuel & 998.00 & 82.00 & 154.00 & 54.33 & 66.77 & 195.24 & 121.10 & 4.23 & 5.11 & 12.13 \\
\hline 05995F & bi-fuel & & & & & & & & & & \\
\hline 05996F & bi-fuel & 1058.00 & 16.00 & 130.00 & 10.60 & 56.37 & 111.59 & 66.97 & 7.25 & 9.48 & 6.33 \\
\hline 05997F & bi-fuel & 1231.30 & 10.60 & 174.10 & 7.02 & 75.49 & 138.61 & 82.51 & 6.67 & 8.88 & 6.70 \\
\hline UT & gasoline & 682.00 & 39.40 & & 26.10 & & 39.40 & 26.10 & 17.31 & 17.31 & 3.83 \\
\hline
\end{tabular}


Table A.1. Monthly Fuel Use Data from Vehicle Operation Log Forms

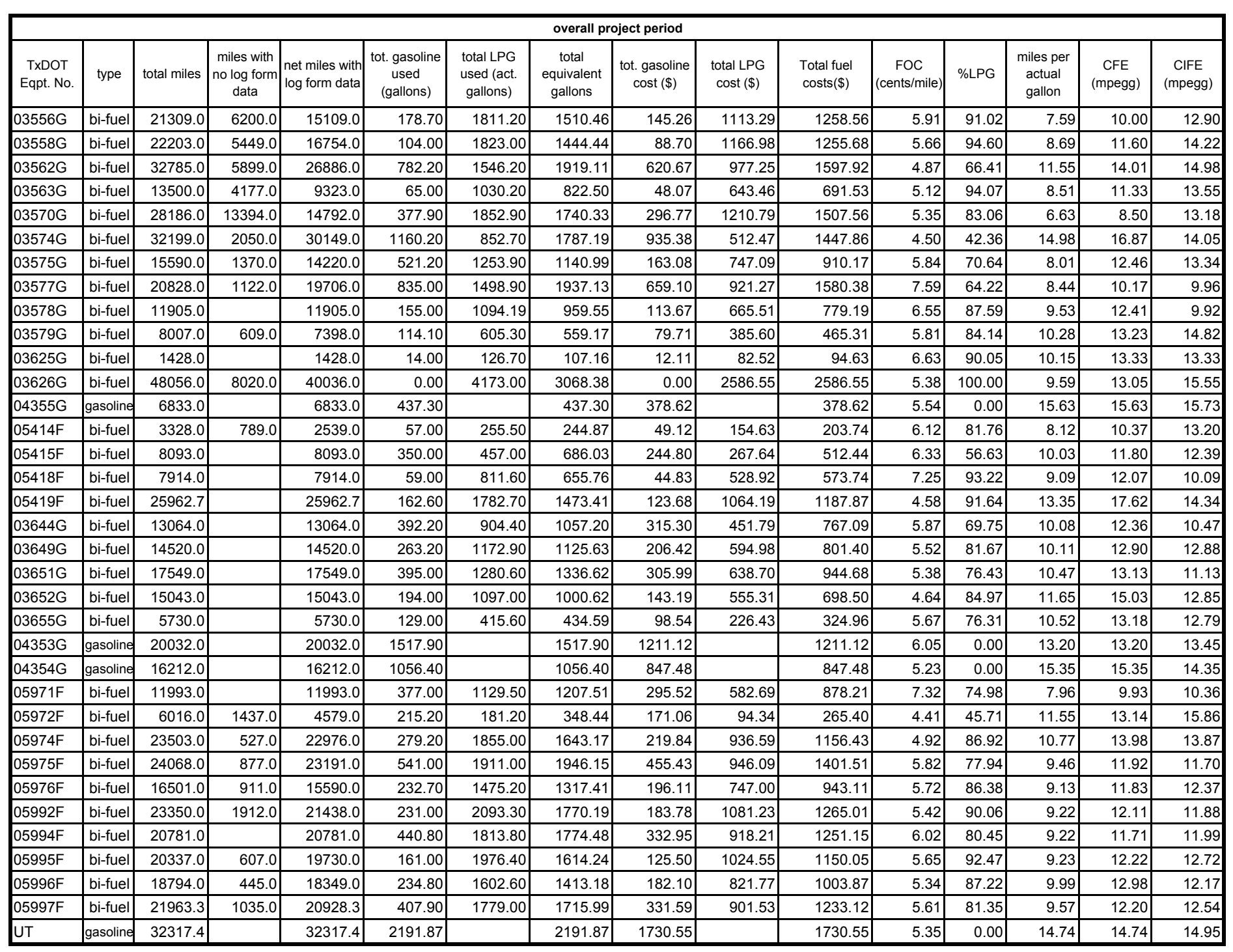


Table A.2. Monthly Fuel Use Data from the TxDOT Database

\begin{tabular}{|c|c|c|c|c|c|c|c|c|c|}
\hline \multicolumn{10}{|c|}{ June-97 } \\
\hline $\begin{array}{l}\text { TxDOT } \\
\text { Equipment } \\
\text { Number }\end{array}$ & type & $\begin{array}{l}\text { miles this } \\
\text { month }\end{array}$ & $\begin{array}{c}\text { gasoline used } \\
\text { (gallons) }\end{array}$ & $\begin{array}{c}\text { gasoline cost } \\
\text { (\$) }\end{array}$ & $\begin{array}{l}\text { LPG used } \\
\text { (actual } \\
\text { gallons) }\end{array}$ & $\begin{array}{l}\text { TxDOT calc. } \\
\text { LPG cost incl. } \\
\text { annual tax }(\$)\end{array}$ & $\begin{array}{c}\text { actual LPG } \\
\text { purchase cost } \\
(\$)\end{array}$ & $\begin{array}{l}\text { miles per } \\
\text { equivalent } \\
\text { gallon } \\
\text { (mpegg) }\end{array}$ & $\begin{array}{l}\text { miles per } \\
\text { actual gallon }\end{array}$ \\
\hline \multicolumn{10}{|c|}{ Corpus Christi District } \\
\hline 03556G & bi-fuel & 827 & 0 & 0.00 & 178 & 127.38 & 115.93 & 6.32 & 4.65 \\
\hline 03558G & bi-fuel & 2421 & 20 & 16.79 & 196 & 131.75 & 127.65 & 14.75 & 11.21 \\
\hline $03562 \mathrm{G}$ & bi-fuel & 2011 & 0 & 0.00 & 138 & 95.28 & 89.88 & 19.82 & 14.57 \\
\hline 03563G & bi-fuel & 870 & 7 & 6.05 & 156 & 112.29 & 101.60 & 7.15 & 5.34 \\
\hline 03570G & bi-fuel & 527 & 16 & 13.91 & 0 & 0.00 & 0.00 & 32.94 & 32.94 \\
\hline $03574 G$ & bi-fuel & 1113 & 157 & 134.88 & 0 & 0.00 & 0.00 & 7.09 & 7.09 \\
\hline $03575 \mathrm{G}$ & bi-fuel & 535 & 0 & 0.00 & 0 & 0.00 & 0.00 & & \\
\hline $03577 \mathrm{G}$ & bi-fuel & 661 & 42 & 35.18 & 43 & 32.68 & 28.01 & 8.98 & 7.78 \\
\hline 03578G & bi-fuel & 0 & 20 & 17.41 & 47 & 29.09 & 30.61 & 0.00 & 0.00 \\
\hline 03579G & bi-fuel & 1129 & 31 & 27.81 & 127 & 88.78 & 82.72 & 9.08 & 7.15 \\
\hline 03625G & bi-fuel & 2420 & 58 & 50.66 & 216 & 111.37 & 140.68 & 11.16 & 8.83 \\
\hline $03626 \mathrm{G}$ & bi-fuel & 2252 & 5 & 4.38 & 0 & 0.00 & 0.00 & 450.40 & 450.40 \\
\hline 04355G & gasoline & 2327 & 108 & 93.38 & 0 & 0.00 & 0.00 & 21.55 & 21.55 \\
\hline $05414 \mathrm{~F}$ & bi-fuel & 0 & 12 & 10.37 & 72 & 48.05 & 46.89 & 0.00 & 0.00 \\
\hline $05415 \mathrm{~F}$ & bi-fuel & 1627 & 82 & 69.93 & 97 & 74.28 & 63.18 & 10.61 & 9.09 \\
\hline $05418 \mathrm{~F}$ & bi-fuel & 536 & 10 & 8.38 & 105 & 164.84 & 68.39 & 6.15 & 4.66 \\
\hline 05419F & bi-fuel & 2145 & 71 & 61.79 & 0 & 168.00 & 0.00 & 30.21 & 30.21 \\
\hline \multicolumn{10}{|c|}{ Houston District } \\
\hline 03644G & bi-fuel & 1052 & 24 & 21.11 & 53 & 29.12 & 28.04 & 16.71 & 13.66 \\
\hline 03649G & bi-fuel & 368 & 0 & 0.00 & 76 & 41.76 & 40.20 & 6.59 & 4.84 \\
\hline $03651 \mathrm{G}$ & bi-fuel & 602 & 17 & 14.99 & 90 & 53.86 & 47.61 & 7.24 & 5.63 \\
\hline $03652 \mathrm{G}$ & bi-fuel & 482 & 0 & 0.00 & 72 & 39.71 & 38.09 & 9.10 & 6.69 \\
\hline $03655 G$ & bi-fuel & 562 & 0 & 0.00 & 18 & 9.85 & 9.52 & 42.46 & 31.22 \\
\hline $04353 G$ & gasoline & 1003 & 72 & 62.84 & 0 & 0.00 & 0.00 & 13.93 & 13.93 \\
\hline $04354 \mathrm{G}$ & gasoline & 772 & 70 & 60.53 & 0 & 0.00 & 0.00 & 11.03 & 11.03 \\
\hline $05971 \mathrm{~F}$ & bi-fuel & 139 & 0 & 0.00 & 21 & 11.61 & 11.11 & 9.00 & 6.62 \\
\hline $05972 \mathrm{~F}$ & bi-fuel & 355 & 11 & 9.55 & 21 & 11.49 & 11.11 & 13.43 & 11.09 \\
\hline 05974F & bi-fuel & 1023 & 0 & 0.00 & 123 & 67.57 & 65.07 & 11.31 & 8.32 \\
\hline $05975 \mathrm{~F}$ & bi-fuel & 897 & 0 & 0.00 & 93 & 51.23 & 49.20 & 13.12 & 9.65 \\
\hline $05976 \mathrm{~F}$ & bi-fuel & 609 & 8 & 6.90 & 66 & 36.06 & 34.91 & 10.77 & 8.23 \\
\hline 05992F & bi-fuel & 893 & 18 & 15.62 & 125 & 72.98 & 66.13 & 8.12 & 6.24 \\
\hline 05994F & bi-fuel & 1360 & 0 & 0.00 & 117 & 64.39 & 61.89 & 15.81 & 11.62 \\
\hline 05995F & bi-fuel & 1152 & 11 & 9.48 & 160 & 88.15 & 84.64 & 8.95 & 6.74 \\
\hline $05996 \mathrm{~F}$ & bi-fuel & 315 & 10 & 8.62 & 43 & 23.59 & 22.75 & 7.57 & 5.94 \\
\hline 05997F & bi-fuel & 1481 & 13 & 11.21 & 155 & 85.13 & 82.00 & 11.66 & 8.82 \\
\hline
\end{tabular}


Table A.2. Monthly Fuel Use Data from the TxDOT Database

\begin{tabular}{|c|c|c|c|c|c|c|c|c|c|}
\hline \multicolumn{10}{|c|}{ July-97 } \\
\hline $\begin{array}{l}\text { TxDOT } \\
\text { Equipment } \\
\text { Number }\end{array}$ & type & $\begin{array}{l}\text { miles this } \\
\text { month }\end{array}$ & $\begin{array}{c}\text { gasoline used } \\
\text { (gallons) }\end{array}$ & $\begin{array}{c}\text { gasoline cost } \\
(\$)\end{array}$ & $\begin{array}{l}\text { LPG used } \\
\text { (actual } \\
\text { gallons) }\end{array}$ & $\begin{array}{l}\text { TxDOT calc. } \\
\text { LPG cost incl. } \\
\text { annual tax }(\$)\end{array}$ & $\begin{array}{c}\text { actual LPG } \\
\text { purchase cost } \\
(\$)\end{array}$ & $\begin{array}{l}\text { miles per } \\
\text { equivalent } \\
\text { gallon } \\
\text { (mpegg) }\end{array}$ & $\begin{array}{l}\text { miles per } \\
\text { actual gallon }\end{array}$ \\
\hline \multicolumn{10}{|c|}{ Corpus Christi District } \\
\hline 03556G & bi-fuel & 1311 & 17 & 14.24 & 307 & 232.26 & 201.30 & 5.40 & 4.05 \\
\hline 03558G & bi-fuel & 3060 & 50 & 41.95 & 224 & 150.53 & 146.88 & 14.25 & 11.17 \\
\hline $03562 \mathrm{G}$ & bi-fuel & 3214 & 116 & 100.52 & 115 & 77.71 & 75.41 & 16.03 & 13.91 \\
\hline 03563G & bi-fuel & 94 & 0 & 0.00 & 75 & 49.37 & 49.18 & 1.70 & 1.25 \\
\hline 03570G & bi-fuel & 1376 & 104 & 91.41 & 251 & 176.03 & 164.58 & 4.77 & 3.88 \\
\hline 03574G & bi-fuel & 2146 & 207 & 174.35 & 0 & 0.00 & 0.00 & 10.37 & 10.37 \\
\hline $03575 \mathrm{G}$ & bi-fuel & 354 & 11 & 8.99 & 73 & 38.08 & 47.87 & 5.47 & 4.21 \\
\hline 03577G & bi-fuel & 2184 & 87 & 72.88 & 288 & 227.26 & 188.84 & 7.31 & 5.82 \\
\hline 03578G & bi-fuel & 2101 & 58 & 48.77 & 139 & 85.43 & 91.14 & 13.11 & 10.66 \\
\hline 03579G & bi-fuel & 2534 & 14 & 12.62 & 142 & 94.83 & 93.11 & 21.40 & 16.24 \\
\hline $03625 \mathrm{G}$ & bi-fuel & 2286 & 241 & 202.20 & 126 & 65.37 & 82.62 & 6.85 & 6.23 \\
\hline 03626G & bi-fuel & 2920 & 33 & 28.24 & 540 & 434.84 & 354.08 & 6.79 & 5.10 \\
\hline 04355G & gasoline & 3081 & 249 & 203.44 & 0 & 0.00 & 0.00 & 12.37 & 12.37 \\
\hline $05414 \mathrm{~F}$ & bi-fuel & 1959 & 27 & 22.80 & 116 & 208.17 & 76.06 & 17.45 & 13.70 \\
\hline $05415 \mathrm{~F}$ & bi-fuel & 3037 & 168 & 141.46 & 250 & 358.57 & 163.93 & 8.63 & 7.27 \\
\hline 05418F & bi-fuel & 1090 & 19 & 15.92 & 191 & 155.38 & 125.24 & 6.84 & 5.19 \\
\hline $05419 \mathrm{~F}$ & bi-fuel & 2966 & 157 & 132.18 & 79 & 48.03 & 51.80 & 13.79 & 12.57 \\
\hline \multicolumn{10}{|c|}{ Houston District } \\
\hline $03644 \mathrm{G}$ & bi-fuel & 971 & 39 & 34.05 & 45 & 24.32 & 24.00 & 13.47 & 11.56 \\
\hline 03649G & bi-fuel & 1382 & 4 & 3.49 & 107 & 57.82 & 57.07 & 16.72 & 12.45 \\
\hline $03651 \mathrm{G}$ & bi-fuel & 1459 & 26 & 22.88 & 141 & 76.12 & 75.21 & 11.25 & 8.74 \\
\hline $03652 \mathrm{G}$ & bi-fuel & 1119 & 9 & 7.92 & 138 & 74.53 & 73.61 & 10.13 & 7.61 \\
\hline $03655 \mathrm{G}$ & bi-fuel & 296 & 8 & 7.04 & 34 & 18.35 & 18.14 & 8.97 & 7.05 \\
\hline $04353 G$ & gasoline & 1847 & 125 & 108.93 & 0 & 0.00 & 0.00 & 14.78 & 14.78 \\
\hline 04354G & gasoline & 1156 & 88 & 77.49 & 0 & 0.00 & 0.00 & 13.14 & 13.14 \\
\hline $05971 \mathrm{~F}$ & bi-fuel & 1111 & 9 & 7.92 & 115 & 62.32 & 61.34 & 11.87 & 8.96 \\
\hline $05972 \mathrm{~F}$ & bi-fuel & 682 & 43 & 37.70 & 20 & 10.81 & 10.67 & 11.82 & 10.83 \\
\hline $05974 \mathrm{~F}$ & bi-fuel & 616 & 13 & 11.45 & 156 & 84.21 & 83.21 & 4.82 & 3.64 \\
\hline 05975F & bi-fuel & 1777 & 15 & 13.10 & 220 & 118.90 & 117.35 & 10.05 & 7.56 \\
\hline $05976 \mathrm{~F}$ & bi-fuel & 2431 & 40 & 34.69 & 220 & 122.63 & 117.35 & 12.05 & 9.35 \\
\hline 05992F & bi-fuel & 1755 & 29 & 25.53 & 216 & 116.65 & 115.21 & 9.34 & 7.16 \\
\hline 05994F & bi-fuel & 1324 & 10 & 8.73 & 151 & 81.61 & 80.54 & 10.94 & 8.22 \\
\hline 05995F & bi-fuel & 1183 & 5 & 4.34 & 186 & 100.41 & 99.21 & 8.34 & 6.19 \\
\hline 05996F & bi-fuel & 961 & 0 & 0.00 & 131 & 70.77 & 69.88 & 9.98 & 7.34 \\
\hline $05997 \mathrm{~F}$ & bi-fuel & 2470 & 3 & 2.62 & 259 & 140.01 & 138.15 & 12.77 & 9.43 \\
\hline
\end{tabular}


Table A.2. Monthly Fuel Use Data from the TxDOT Database

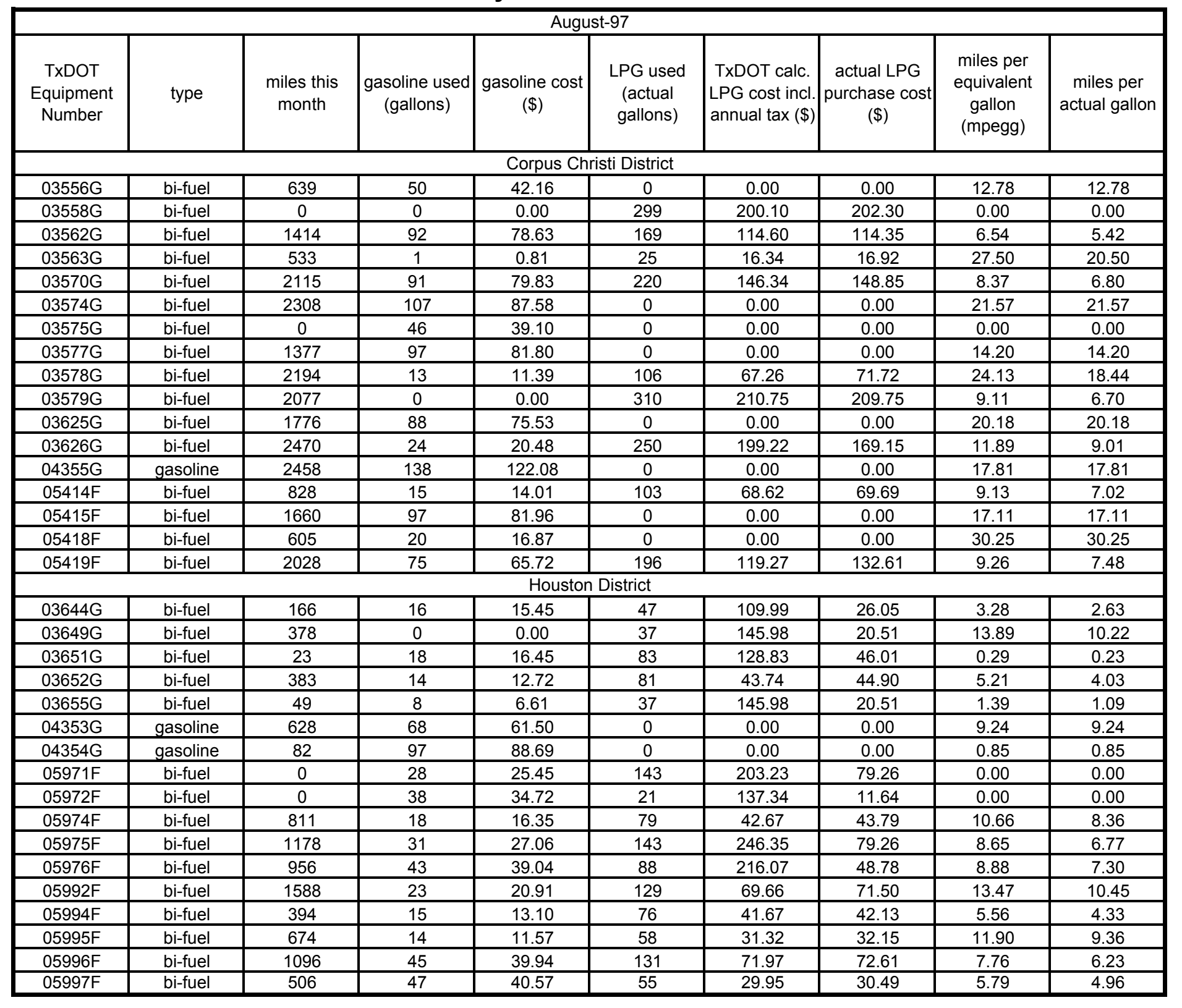


Table A.2. Monthly Fuel Use Data from the TxDOT Database

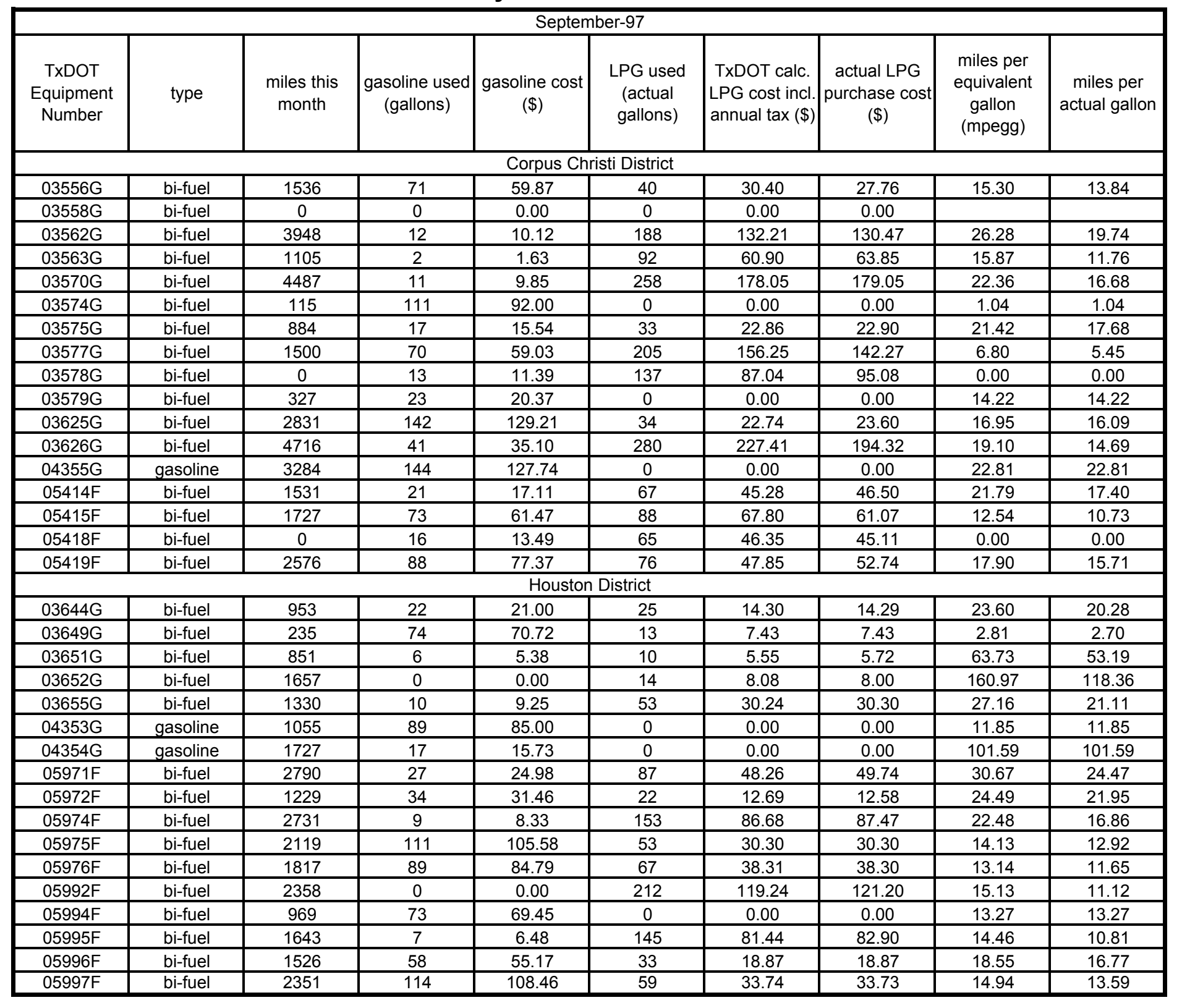


Table A.2. Monthly Fuel Use Data from the TxDOT Database

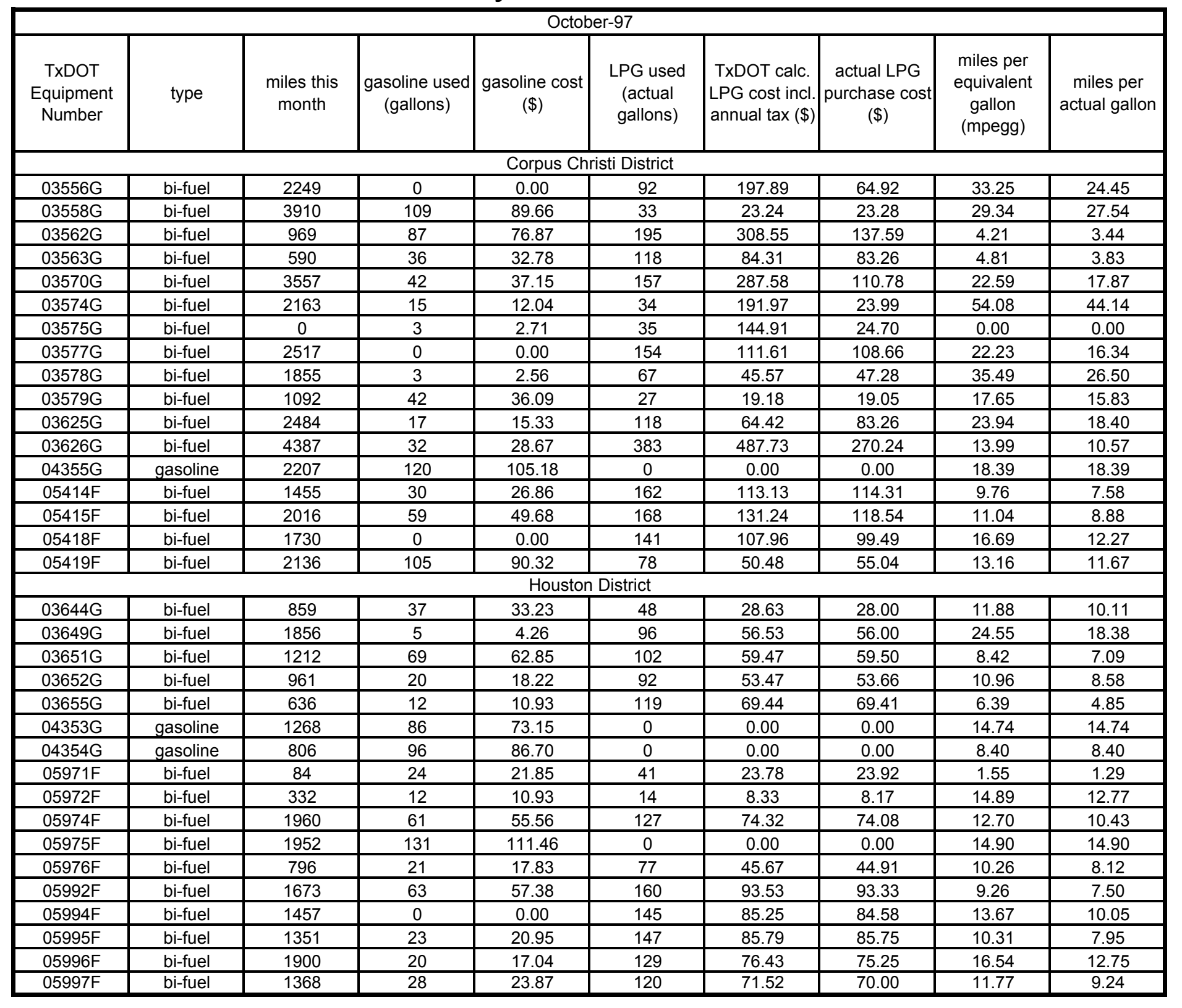


Table A.2. Monthly Fuel Use Data from the TxDOT Database

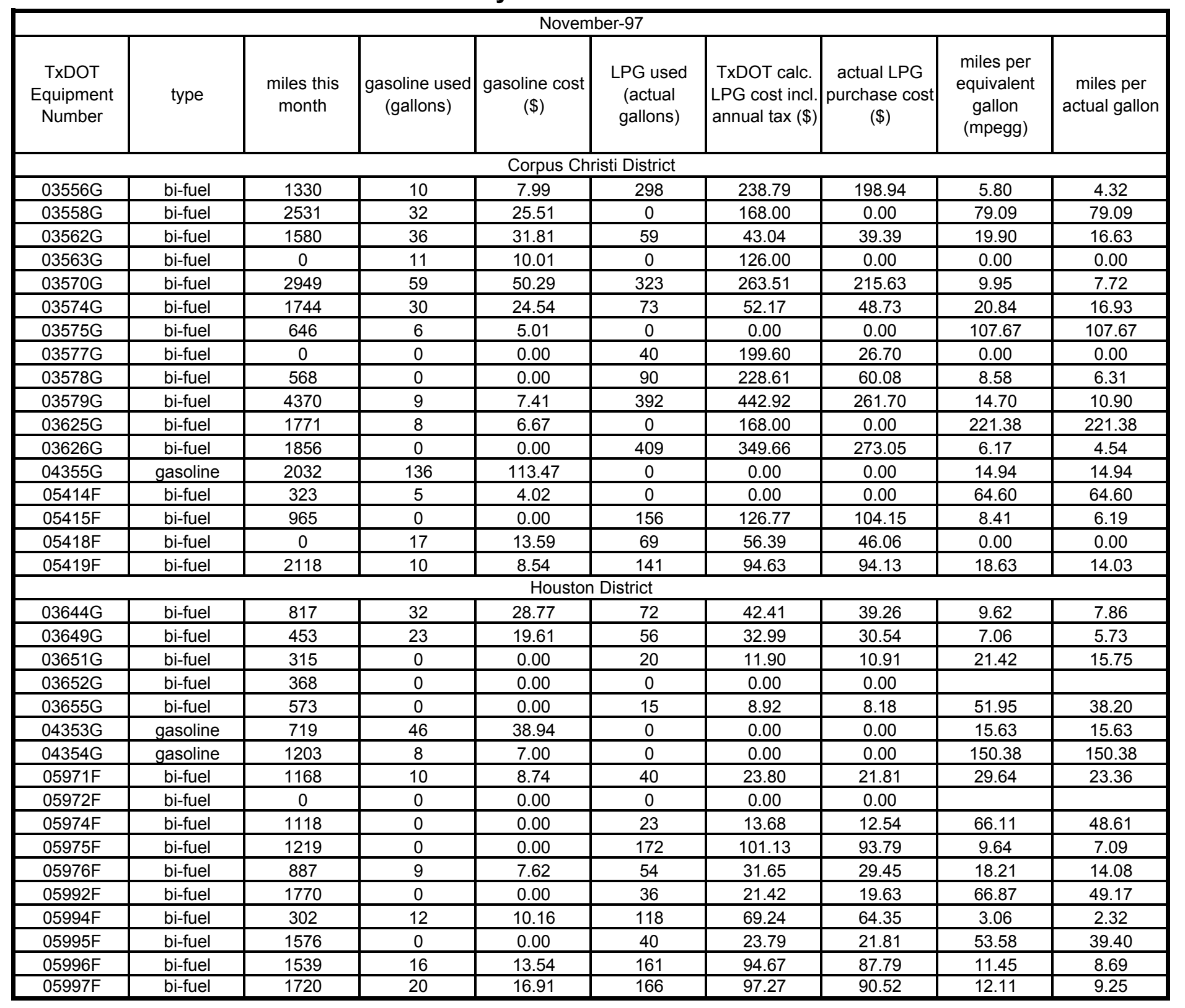


Table A.2. Monthly Fuel Use Data from the TxDOT Database

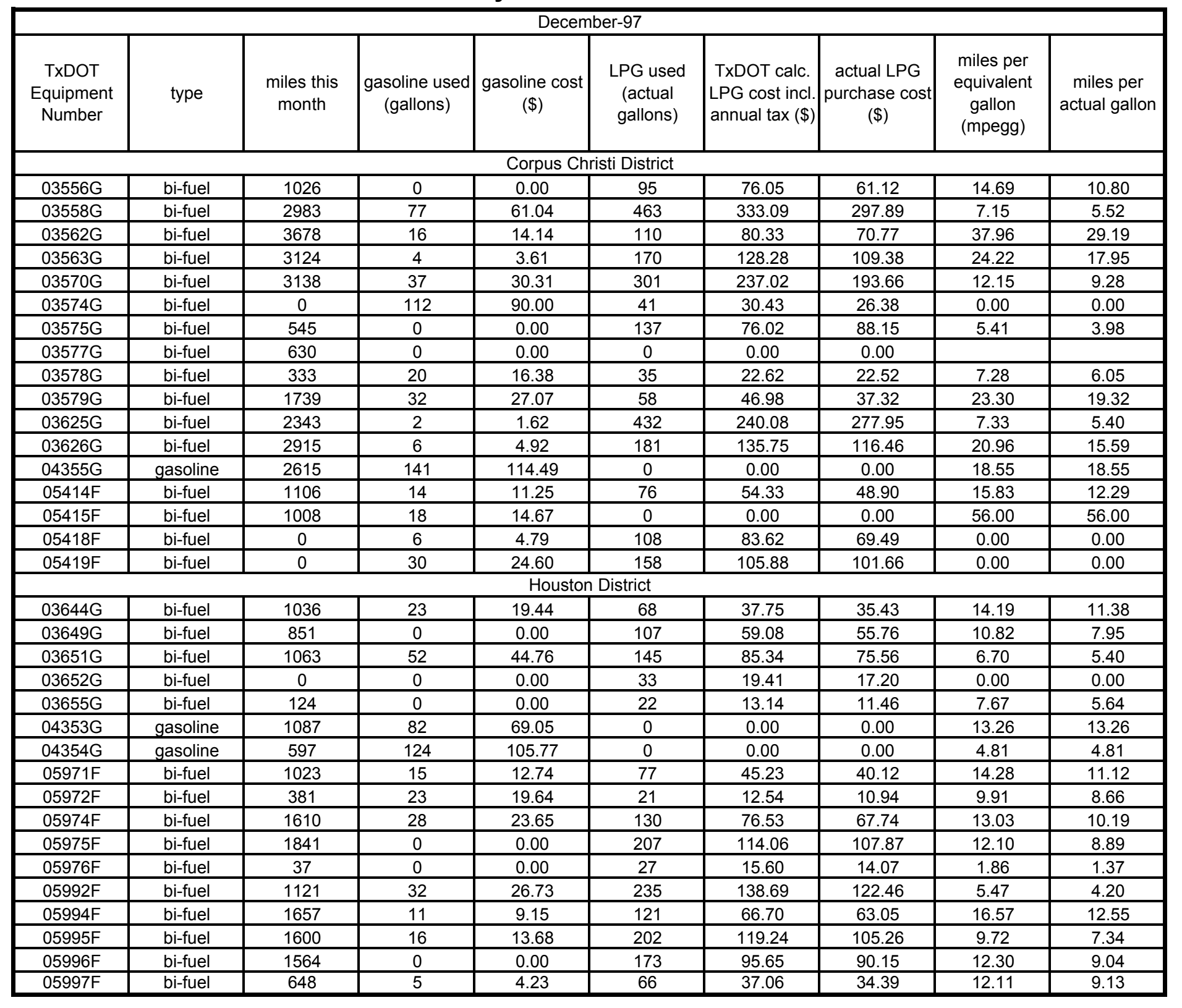


Table A.2. Monthly Fuel Use Data from the TxDOT Database

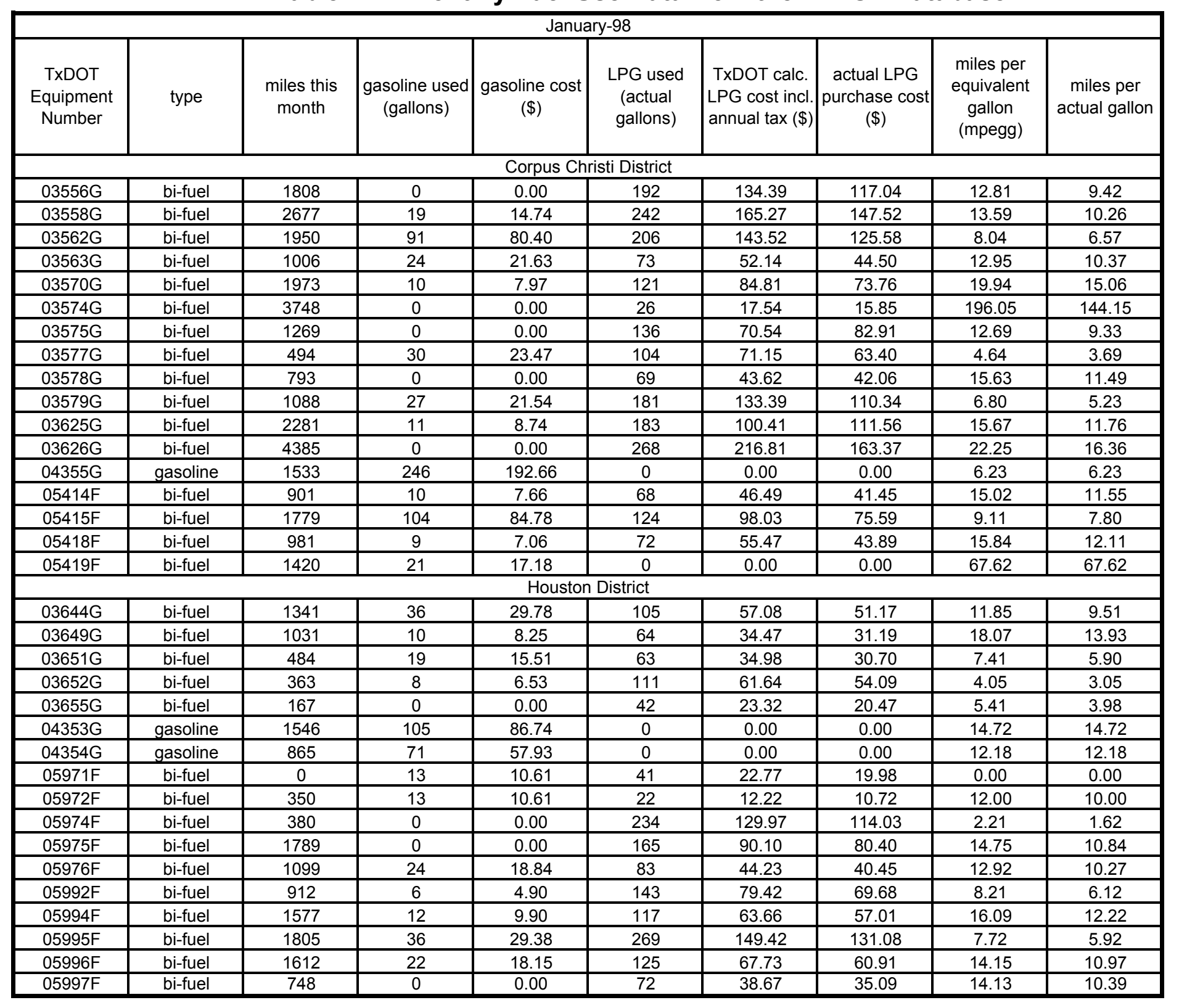


Table A.2. Monthly Fuel Use Data from the TxDOT Database

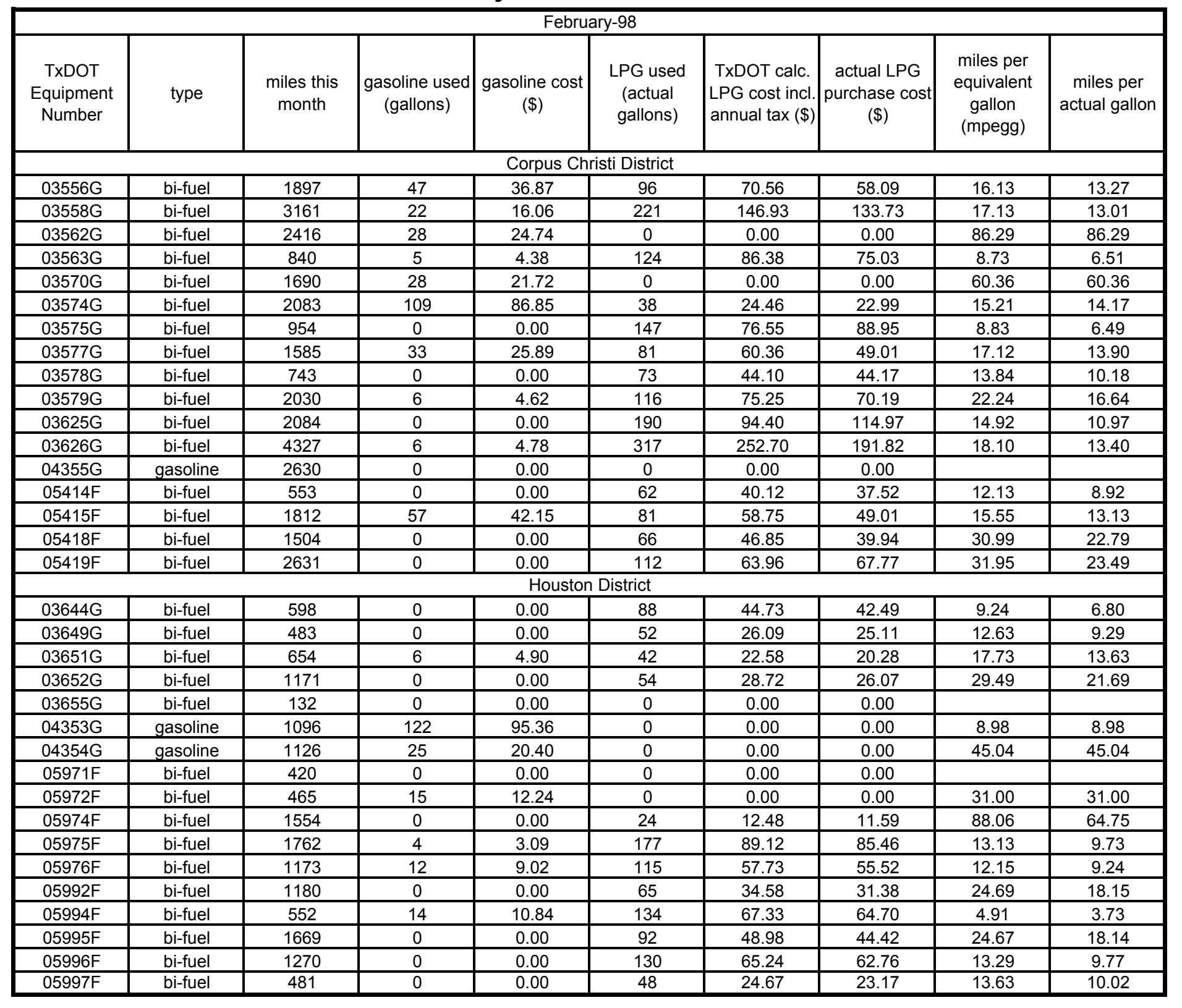


Table A.2. Monthly Fuel Use Data from the TxDOT Database

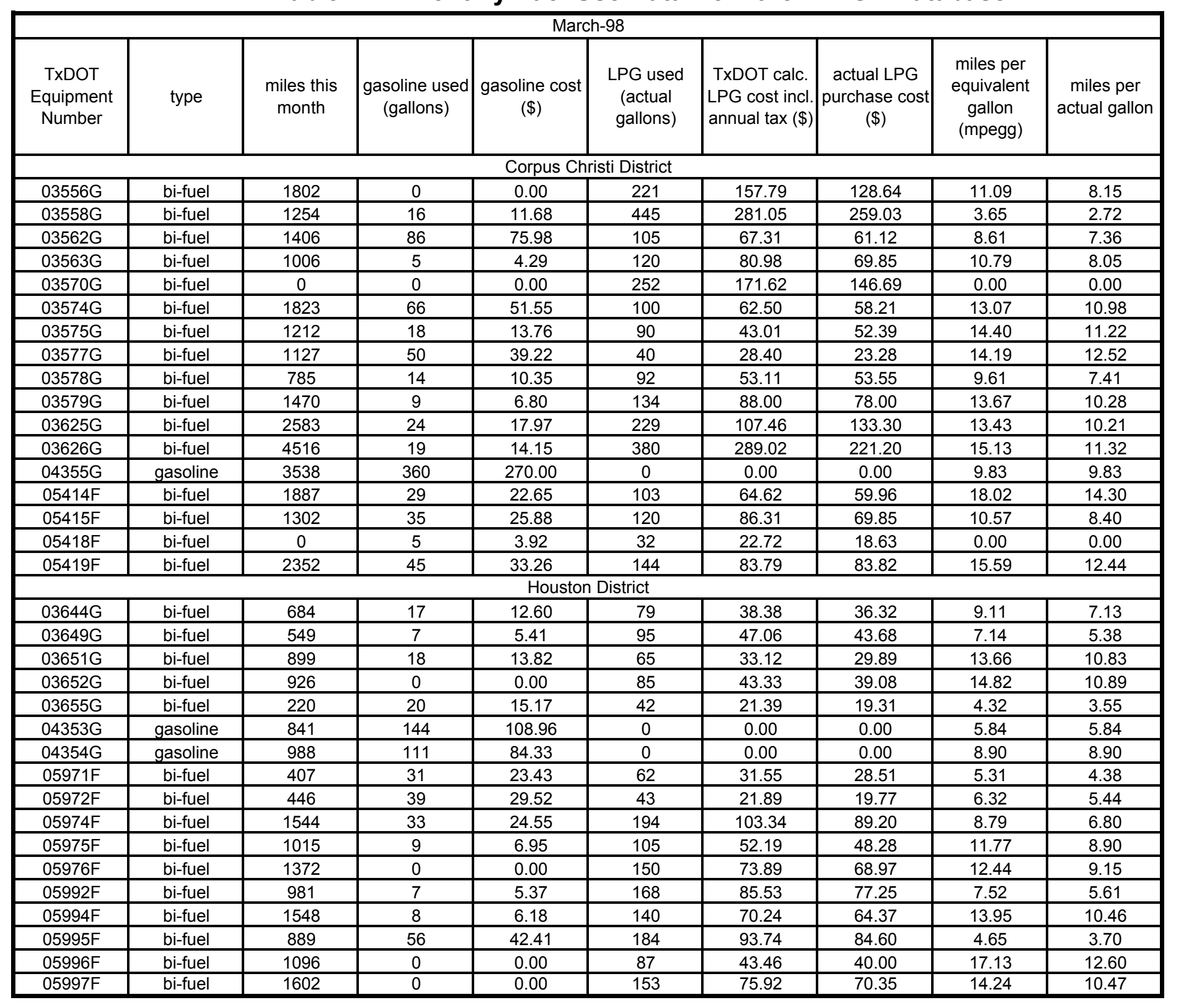


Table A.2. Monthly Fuel Use Data from the TxDOT Database

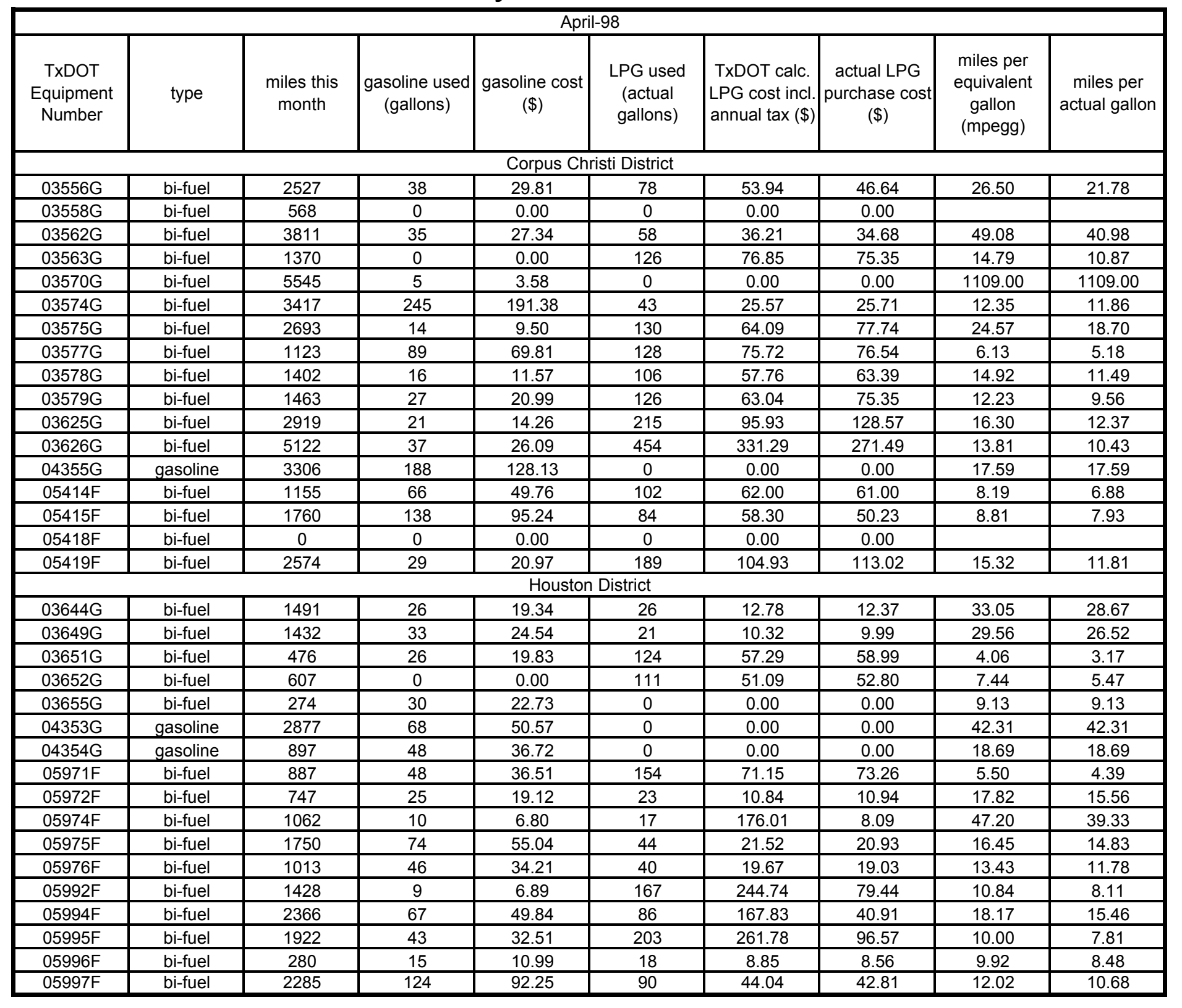


Table A.2. Monthly Fuel Use Data from the TxDOT Database

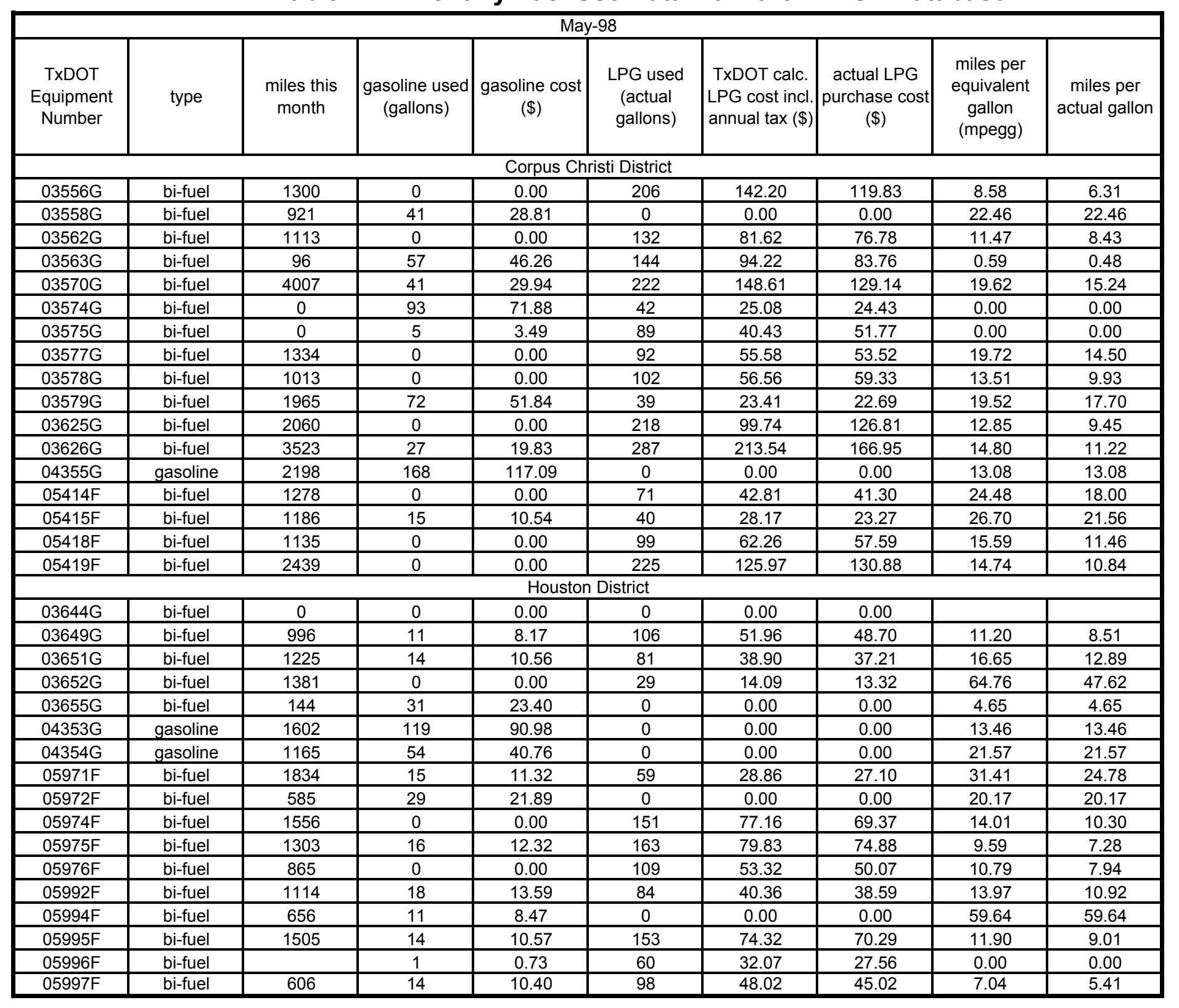


Table A.2. Monthly Fuel Use Data from the TxDOT Database

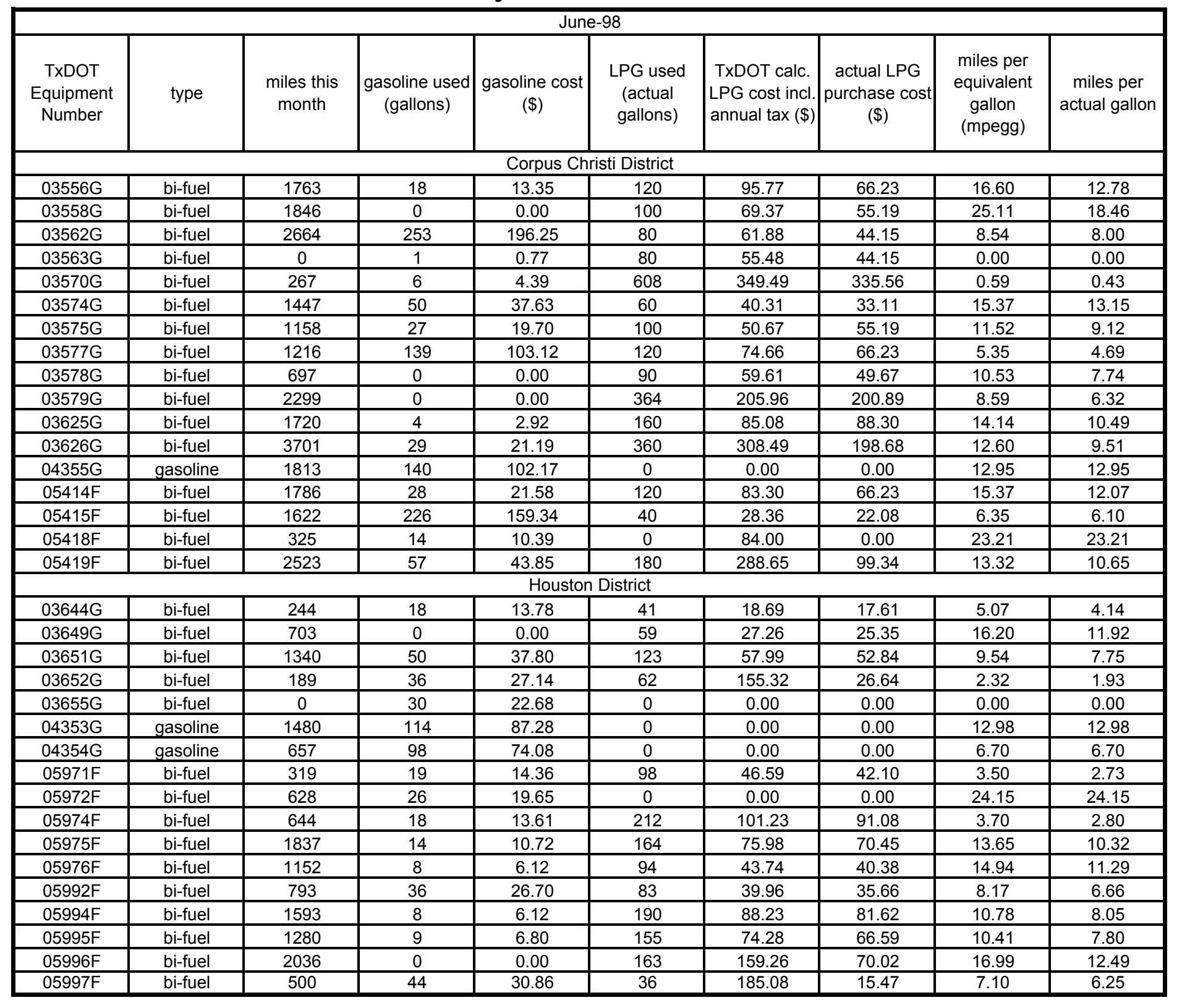


Table A.2. Monthly Fuel Use Data from the TxDOT Database

\begin{tabular}{|c|c|c|c|c|c|c|c|c|c|}
\hline \multicolumn{10}{|c|}{ July-98 } \\
\hline $\begin{array}{l}\text { TxDOT } \\
\text { Equipment } \\
\text { Number }\end{array}$ & type & $\begin{array}{l}\text { miles this } \\
\text { month }\end{array}$ & $\begin{array}{c}\text { gasoline used } \\
\text { (gallons) }\end{array}$ & $\begin{array}{c}\text { gasoline cost } \\
(\$)\end{array}$ & $\begin{array}{l}\text { LPG used } \\
\text { (actual } \\
\text { gallons) }\end{array}$ & $\begin{array}{l}\text { TxDOT calc. } \\
\text { LPG cost incl. } \\
\text { annual tax }(\$)\end{array}$ & $\begin{array}{c}\text { actual LPG } \\
\text { purchase cost } \\
(\$)\end{array}$ & $\begin{array}{l}\text { miles per } \\
\text { equivalent } \\
\text { gallon } \\
\text { (mpegg) }\end{array}$ & $\begin{array}{l}\text { miles per } \\
\text { actual gallon }\end{array}$ \\
\hline \multicolumn{10}{|c|}{ Corpus Christi District } \\
\hline 03556G & bi-fuel & 1579 & 7 & 5.19 & 160 & 124.59 & 88.50 & 12.67 & 9.46 \\
\hline $03558 \mathrm{G}$ & bi-fuel & 1841 & 27 & 19.39 & 130 & 87.52 & 71.90 & 15.02 & 11.73 \\
\hline $03562 \mathrm{G}$ & bi-fuel & 1324 & 106 & 82.62 & 120 & 87.04 & 66.37 & 6.82 & 5.86 \\
\hline $03563 G$ & bi-fuel & 1771 & 75 & 57.04 & 343 & 181.97 & 189.71 & 5.41 & 4.24 \\
\hline 03570G & bi-fuel & 316 & 20 & 14.25 & 0 & 0.00 & 0.00 & 15.80 & 15.80 \\
\hline $03574 G$ & bi-fuel & 2691 & 175 & 129.19 & 100 & 67.57 & 55.31 & 10.83 & 9.79 \\
\hline $03575 G$ & bi-fuel & 2075 & 0 & 0.00 & 150 & 73.79 & 82.97 & 18.81 & 13.83 \\
\hline $03577 \mathrm{G}$ & bi-fuel & 1473 & 80 & 59.35 & 120 & 77.44 & 66.37 & 8.76 & 7.37 \\
\hline 03578G & bi-fuel & 759 & 36 & 26.10 & 80 & 53.41 & 44.25 & 8.00 & 6.54 \\
\hline $03579 \mathrm{G}$ & bi-fuel & 1819 & 49 & 37.30 & 82 & 51.37 & 45.35 & 16.64 & 13.89 \\
\hline $03625 \mathrm{G}$ & bi-fuel & 3105 & 0 & 0.00 & 130 & 59.38 & 71.90 & 32.48 & 23.88 \\
\hline $03626 \mathrm{G}$ & bi-fuel & 4454 & 54 & 38.54 & 290 & 232.89 & 160.40 & 16.67 & 12.95 \\
\hline $04355 \mathrm{G}$ & gasoline & 3338 & 23 & 16.81 & 0 & 0.00 & 0.00 & 145.13 & 145.13 \\
\hline 05414F & bi-fuel & 1045 & 15 & 11.48 & 80 & 57.24 & 44.25 & 14.16 & 11.00 \\
\hline $05415 \mathrm{~F}$ & bi-fuel & 1162 & 82 & 49.56 & 0 & 0.00 & 0.00 & 14.17 & 14.17 \\
\hline $05418 \mathrm{~F}$ & bi-fuel & 1388 & 23 & 17.06 & 70 & 47.02 & 38.72 & 18.64 & 14.92 \\
\hline 05419F & bi-fuel & 2783 & 48 & 34.75 & 150 & 97.66 & 82.97 & 17.58 & 14.06 \\
\hline \multicolumn{10}{|c|}{ Houston District } \\
\hline $03644 G$ & bi-fuel & 769 & 0 & 0.00 & 91 & 40.03 & 39.20 & 11.49 & 8.45 \\
\hline 03649G & bi-fuel & 1371 & 18 & 13.44 & 131 & 57.59 & 56.43 & 11.99 & 9.20 \\
\hline $03651 \mathrm{G}$ & bi-fuel & 1574 & 17 & 12.41 & 190 & 87.16 & 81.85 & 10.04 & 7.60 \\
\hline $03652 \mathrm{G}$ & bi-fuel & 949 & 0 & 0.00 & 113 & 50.33 & 48.68 & 11.42 & 8.40 \\
\hline $03655 G$ & bi-fuel & 596 & 0 & 0.00 & 54 & 24.21 & 23.26 & 15.01 & 11.04 \\
\hline $04353 G$ & gasoline & 1400 & 94 & 70.41 & 0 & 0.00 & 0.00 & 14.89 & 14.89 \\
\hline $04354 G$ & gasoline & 1090 & 61 & 44.55 & 0 & 0.00 & 0.00 & 17.87 & 17.87 \\
\hline $05971 \mathrm{~F}$ & bi-fuel & 553 & 13 & 9.50 & 85 & 37.93 & 36.62 & 7.32 & 5.64 \\
\hline $05972 \mathrm{~F}$ & bi-fuel & 418 & 21 & 15.33 & 0 & 0.00 & 0.00 & 19.90 & 19.90 \\
\hline 05974F & bi-fuel & 1986 & 0 & 0.00 & 159 & 70.71 & 68.50 & 16.99 & 12.49 \\
\hline 05975F & bi-fuel & 783 & 14 & 10.05 & 129 & 56.64 & 55.57 & 7.19 & 5.48 \\
\hline 05976F & bi-fuel & 871 & 6 & 4.51 & 125 & 54.94 & 53.85 & 8.90 & 6.65 \\
\hline $05992 \mathrm{~F}$ & bi-fuel & 2207 & 41 & 29.21 & 210 & 93.45 & 90.47 & 11.29 & 8.79 \\
\hline 05994F & bi-fuel & 2008 & 14 & 10.52 & 242 & 112.28 & 104.25 & 10.46 & 7.84 \\
\hline 05995F & bi-fuel & 888 & 9 & 6.80 & 86 & 38.67 & 37.05 & 12.29 & 9.35 \\
\hline 05996F & bi-fuel & 547 & 0 & 0.00 & 101 & 44.37 & 43.51 & 7.37 & 5.42 \\
\hline 05997F & bi-fuel & 1796 & 48 & 36.03 & 160 & 70.32 & 68.93 & 10.84 & 8.63 \\
\hline
\end{tabular}


Table A.2. Monthly Fuel Use Data from the TxDOT Database

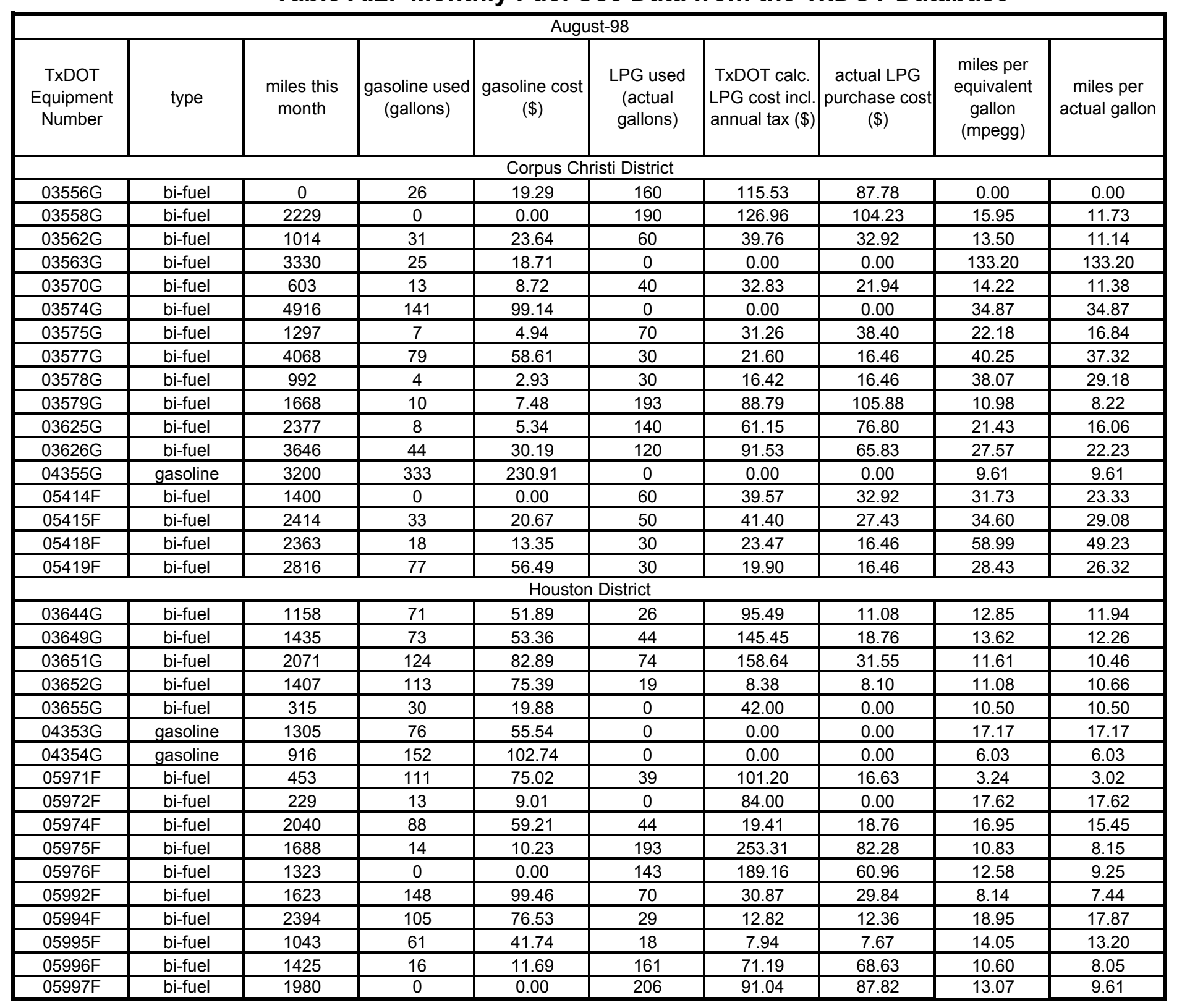


Table A.2. Monthly Fuel Use Data from the TxDOT Database

\begin{tabular}{|c|c|c|c|c|c|c|c|c|c|}
\hline \multicolumn{10}{|c|}{ September-98 } \\
\hline $\begin{array}{l}\text { TxDOT } \\
\text { Equipment } \\
\text { Number }\end{array}$ & type & $\begin{array}{l}\text { miles this } \\
\text { month }\end{array}$ & $\begin{array}{c}\text { gasoline used } \\
\text { (gallons) }\end{array}$ & $\begin{array}{c}\text { gasoline cost } \\
(\$)\end{array}$ & $\begin{array}{l}\text { LPG used } \\
\text { (actual } \\
\text { gallons) }\end{array}$ & $\begin{array}{l}\text { TxDOT calc. } \\
\text { LPG cost incl. } \\
\text { annual tax }(\$)\end{array}$ & $\begin{array}{c}\text { actual LPG } \\
\text { purchase cost } \\
(\$)\end{array}$ & $\begin{array}{l}\text { miles per } \\
\text { equivalent } \\
\text { gallon } \\
\text { (mpegg) }\end{array}$ & $\begin{array}{l}\text { miles per } \\
\text { actual gallon }\end{array}$ \\
\hline \multicolumn{10}{|c|}{ Corpus Christi District } \\
\hline 03556G & bi-fuel & 2472 & 0 & 0.00 & 150 & 114.35 & 83.39 & 22.41 & 16.48 \\
\hline 03558G & bi-fuel & 2560 & 23 & 14.34 & 210 & 135.14 & 116.74 & 14.43 & 10.99 \\
\hline 03562G & bi-fuel & 6940 & 0 & 0.00 & 230 & 182.26 & 127.86 & 41.04 & 30.17 \\
\hline $03563 G$ & bi-fuel & 0 & 0 & 0.00 & 0 & 0.00 & 0.00 & & \\
\hline 03570G & bi-fuel & 1261 & 178 & 118.20 & 150 & 113.51 & 83.39 & 4.37 & 3.84 \\
\hline 03574G & bi-fuel & 0 & 115 & 77.39 & 210 & 132.34 & 116.74 & 0.00 & 0.00 \\
\hline 03575G & bi-fuel & 1896 & 95 & 61.73 & 190 & 95.96 & 105.62 & 8.08 & 6.65 \\
\hline $03577 \mathrm{G}$ & bi-fuel & 1291 & 0 & 0.00 & 180 & 110.50 & 100.06 & 9.75 & 7.17 \\
\hline $03578 \mathrm{G}$ & bi-fuel & 2308 & 96 & 61.35 & 200 & 115.18 & 111.18 & 9.50 & 7.80 \\
\hline 03579G & bi-fuel & 3038 & 105 & 74.17 & 80 & 45.62 & 44.47 & 18.54 & 16.42 \\
\hline $03625 G$ & bi-fuel & 2761 & 27 & 17.55 & 360 & 160.25 & 200.12 & 9.47 & 7.13 \\
\hline $03626 G$ & bi-fuel & 970 & 0 & 0.00 & 470 & 379.64 & 261.27 & 2.81 & 2.06 \\
\hline $04355 \mathrm{G}$ & gasoline & 1826 & 113 & 73.65 & 0 & 0.00 & 0.00 & 16.16 & 16.16 \\
\hline $05414 \mathrm{~F}$ & bi-fuel & 205 & 22 & 14.80 & 130 & 173.28 & 72.27 & 1.74 & 1.35 \\
\hline $05415 F$ & bi-fuel & 3010 & 221 & 139.78 & 230 & 168.87 & 127.86 & 7.72 & 6.67 \\
\hline $05418 \mathrm{~F}$ & bi-fuel & 0 & 0 & 0.00 & 190 & 141.16 & 105.62 & 0.00 & 0.00 \\
\hline $05419 \mathrm{~F}$ & bi-fuel & 1541 & 19 & 12.26 & 360 & 210.61 & 200.12 & 5.43 & 4.07 \\
\hline \multicolumn{10}{|c|}{ Houston District } \\
\hline 03644G & bi-fuel & 1445 & 66 & 46.23 & 24 & 10.58 & 10.41 & 17.27 & 16.06 \\
\hline 03649G & bi-fuel & 913 & 46 & 32.30 & 82 & 36.65 & 35.56 & 8.59 & 7.13 \\
\hline $03651 \mathrm{G}$ & bi-fuel & 1386 & 29 & 18.57 & 100 & 44.16 & 43.36 & 13.52 & 10.74 \\
\hline $03652 \mathrm{G}$ & bi-fuel & 1435 & 13 & 8.30 & 56 & 24.78 & 24.28 & 26.49 & 20.80 \\
\hline $03655 G$ & bi-fuel & 258 & 27 & 17.24 & 0 & 0.00 & 0.00 & 9.56 & 9.56 \\
\hline 04353G & gasoline & 930 & 77 & 54.31 & 0 & 0.00 & 0.00 & 12.08 & 12.08 \\
\hline 04354G & gasoline & 1561 & 52 & 33.11 & 0 & 0.00 & 0.00 & 30.02 & 30.02 \\
\hline $05971 \mathrm{~F}$ & bi-fuel & 590 & 0 & 0.00 & 68 & 29.91 & 29.48 & 11.80 & 8.68 \\
\hline $05972 \mathrm{~F}$ & bi-fuel & 316 & 42 & 26.95 & 0 & 0.00 & 0.00 & 7.52 & 7.52 \\
\hline 05974F & bi-fuel & 1384 & 14 & 9.07 & 155 & 68.30 & 67.21 & 10.81 & 8.19 \\
\hline $05975 \mathrm{~F}$ & bi-fuel & 2057 & 6 & 4.17 & 173 & 76.30 & 75.01 & 15.44 & 11.49 \\
\hline 05976F & bi-fuel & 1503 & 8 & 5.56 & 160 & 70.57 & 69.38 & 11.96 & 8.95 \\
\hline 05992F & bi-fuel & 1621 & 33 & 21.15 & 118 & 52.22 & 51.16 & 13.53 & 10.74 \\
\hline 05994F & bi-fuel & 2874 & 132 & 93.04 & 113 & 50.46 & 49.00 & 13.36 & 11.73 \\
\hline $05995 \mathrm{~F}$ & bi-fuel & 769 & 43 & 27.81 & 0 & 0.00 & 0.00 & 17.88 & 17.88 \\
\hline 05996F & bi-fuel & 1233 & 0 & 0.00 & 126 & 55.66 & 54.63 & 13.31 & 9.79 \\
\hline 05997F & bi-fuel & 1764 & 33 & 22.52 & 162 & 71.34 & 70.24 & 11.60 & 9.05 \\
\hline
\end{tabular}


Table A.2. Monthly Fuel Use Data from the TxDOT Database

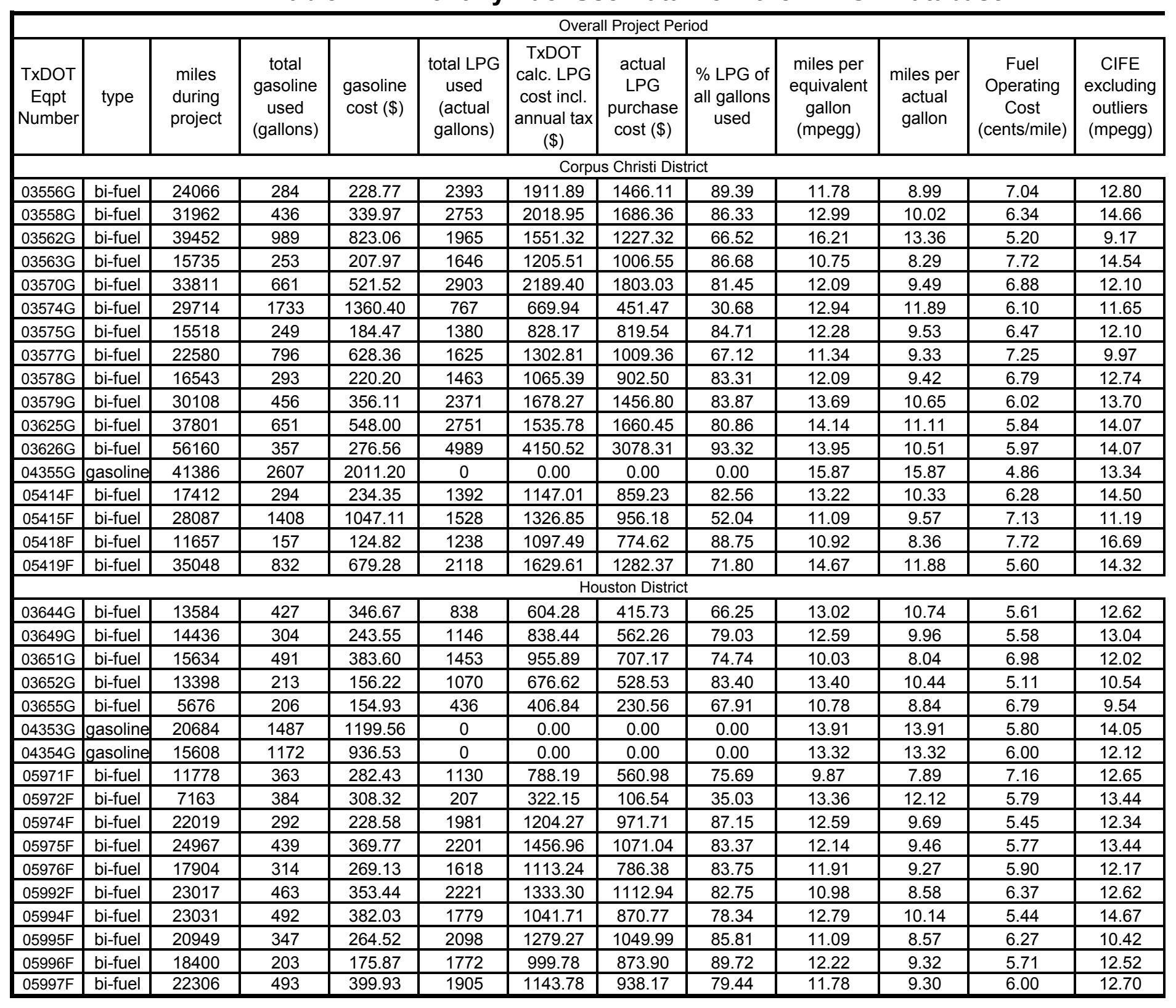




\section{Appendix B: \\ Methods for Determining Combined Fuel Economy and Fuel Operating Cost}

Data suitable for determining fuel economy, percent use of LPG, and fuel operating costs are available from both the vehicle operation log forms and the TxDOT database. However, data entries in the database are delayed and are neither date stamped nor mileage stamped (other than the final odometer reading) and, therefore, cannot be precisely aligned with the vehicle operation $\log$ forms. Thus, these two sources of data cannot yield precise agreement. However, over a reasonably long time period, such as the present project, discrepancies between the two will be minimized. The methods used to calculate the parameters that are related to the fuel operating cost are discussed in this appendix. Example calculations are provided in the final section.

\section{Energy Contents of LPG and Gasoline}

Because 31 of the 35 study vehicles were bi-fueled, determination of the combined fuel economy relied on the theoretical relationship between the chemical energy per LPG gallon and that for gasoline, as verified by results from this study (Table 2) and by prior investigations (Matthews et al., 1996; Chiu and Matthews, 1996; Wu et al., 1996, 1998a). The energy content (Net Heating Value) of a gallon of standard gasoline is defined in the U.S. Code of Federal Regulations (CFR 40 , Section 600.113) to be $114,132 \mathrm{Btu} /$ gallon. A standard energy content is not available for LPG because its composition varies depending on the source of the LPG (i.e., produced from crude oil or stripped from natural gas). However, a study of the LPG in Texas found that the Coefficient of Variability (the standard deviation normalized by the mean) of the mass-based Net Heating Value was less than 0.4\%, and the mean was 19,967 Btu/lb (Wu et al., 1998b). The density of LPG is $4.2 \mathrm{lb} /$ gallon. Thus, the volume-based Net Heating Value for the LPG in Texas is 83,861 Btu per LPG gallon. Taking the ratio of these two volume-based Net Heating Values yields the conclusion that 1.36 gallons of LPG has the same energy as 1 gallon of gasoline.

\section{Equations}

The following parameters are defined for the fuel economy, fuel operating cost, and percent LPG usage calculations:

- Vehicle operation log form, VOLF

- TxDOT database download, DB

- Total miles driven, TMD $=[$ (odometer reading at end) - (odometer reading at start) $]$ [(odometer reading at new data entry) - (odometer reading before missing data entry)] over the project period, from VOLF

- Total LPG used, TPU = cumulative LPG used over the project period, from VOLF

- Total gasoline used, TGU = cumulative gasoline used over the project period, from VOLF

- Total cost of LPG used, TPC = cumulative LPG cost in the project period

Equations B.1-B.5 were used to perform calculations for the data on the vehicle operation $\log$ forms. 


$$
\text { TPC }[\$]=\text { TPU [LPG gallons] *SPC' [\$/LPG gallon] }
$$

where SPC' is the LPG cost calculated from TxDOT monthly records for the actual LPG purchase price (\$/LPG gallon).

Total cost of gasoline used, $\mathrm{TGC}=$ cumulative gasoline cost in the project period:

$$
\text { TGC }[\$]=\text { TGU [gasoline gallons] *SGC' [\$/gasoline gallon] }
$$

where $\mathrm{SGC}^{\prime}$ is the gasoline cost paid by TxDOT.

Fuel operating cost, FOC, over the project period:

$$
\text { FOC }[\$ / \text { mile }]=(\mathrm{TPC}+\mathrm{TGC}) / \mathrm{TMD}
$$

Combined fuel economy, CFE, over the project period:

$$
\begin{gathered}
\mathrm{CFE}[\mathrm{mpegg}]=\mathrm{TMD}[\mathrm{mi}] /\left(\left\{\mathrm{TPU}[\mathrm{LPG} \text { gallons}]^{*}(1 / 1.36) \text { [gasoline gal./LPG gal. }\right]\right\} \\
+ \text { TGU [gasoline gallons }])
\end{gathered}
$$

Percentage LPG used in this 6 month period, \%LPG

$$
\% \mathrm{LPG}=\mathrm{TPU} /(\mathrm{TPU}+\mathrm{TGU})
$$

Similar calculations were done using the results from the TxDOT database via the following definitions and equations:

- $\quad$ Total miles driven, TMD' = over the project period, from DB

- Total LPG used, TPU' = cumulative LPG used over the project period, from DB

- Total gasoline used, TGU' = cumulative gasoline used over the project period, from DB

- Total cost of LPG used, TPC' = cumulative LPG cost over the project period, from DB

$$
\mathrm{TPC}^{\prime}=\mathrm{TPU}^{\prime *} \mathrm{SPC}^{\prime}
$$

Total cost of gasoline used, $\mathrm{TGC}^{\prime}=$ cumulative gasoline cost over the project period, from $\mathrm{DB}$

Combined fuel economy, CFE', over the project period:

$$
\begin{gathered}
\mathrm{CFE}^{\prime}[\mathrm{mpegg}]=\mathrm{TMD}^{\prime}[\mathrm{mi}] /\left(\left\{\mathrm{TPU}^{\prime}[\mathrm{LPG} \text { gallons}]^{*}(1 / 1.36)[\text { gasoline gal./LPG gal.] }\}\right.\right. \\
+ \text { TGU' [gasoline gallons }])
\end{gathered}
$$

Fuel operating cost, FOC', over the project period:

$$
\mathrm{FOC}^{\prime}[\$ / \text { mile }]=\left(\mathrm{TPC}^{\prime}+\mathrm{TGC}^{\prime}\right) / \mathrm{TMD}^{\prime}
$$

Note that the TxDOT database's timelines are not as current as those of the vehicle operation log forms. TxDOT sent us data about our project vehicles each month, such as the cumulative fuel used since the vehicle went into service. The fuel usage for each month can be obtained by subtracting the corresponding data submitted during the previous month from those for the present month. Unfortunately, the data submitted by the local drivers to their districts and the timing of the districts entering of the data into the database are not fixed or regular. Therefore, the database records do not always correspond to the log form records for each specific vehicle. For example, the LPG usage of Vehicle $03556 \mathrm{G}$ in October 1997 was 92 gallons in TxDOT's 
monthly data, but the vehicle operation log form showed the LPG usage in that month was 262.1 gallons.

To account for this, in the calculations presented above, the results are calculated over a long time (and/or mileage) increment. The advantage of this approach, when applied to the data from the vehicle operation log forms, is that it minimizes inaccuracies resulting from mismatches in the odometer reading and/or fuel quantity data for a specific refill. For the results from the TxDOT database, the advantages of this long-term approach are that it both compensates for data entry errors and for delays in data entry. However, for the analyses from the vehicle operation $\log$ forms, this approach suffers if a driver entirely skipped entering a record for a refill (in the case of the database, the fuel quantity will eventually get entered from the payment records via the Accounting Office). Thus, a third method for determining the combined fuel economy is analysis of the data on the vehicle operating log forms, combining the results for every refueling entry each month:

Combined incremental fuel economy, CIFE, over each monthly period:

$$
\begin{gathered}
\text { CIFE }[\mathrm{mpegg}]=\mathrm{IMD}[\mathrm{mi}] /\left(\left\{\mathrm{IPU}[\mathrm{LPG} \text { gallons }]^{*}(1 / 1.36) \text { [gasoline gal./LPG gal. }\right]\right\} \\
+ \text { IGU } \text { [gasoline gallons }])
\end{gathered}
$$

where:

- Incremental miles driven, IMD = miles driven that month

- Incremental LPG usage, IPU = LPG gallons added that month

- Incremental gasoline usage, IGU = gasoline gallons added that month.

Statistical analysis of the results obtained via Equation B.9 should reveal outliers (unrealistically high values for the combined incremental fuel economy) that result from missing or incorrect refueling records on the vehicle operation log forms. Equation B.9 was also applied to the monthly database records, yielding the fourth measure of fuel economy. Outliers were identified as having a fuel economy that is more than two standard deviations from the mean. After elimination of these outliers, a revised average was calculated.

\section{Example Calculations}

As an example of the calculations performed, assume the following data for three vehicles:

Table B-1. Data for Example Calculations

$\begin{array}{cccc}\text { ID } & \text { miles } & \text { LPG gallons } & \text { gasoline gallons } \\ & (\mathbf{T M D}) & (\mathbf{T P U}) & 800 \\ 1 & 10,160 & 0 & 0 \\ 2 & 9,338 & 1000 & 220 \\ 3 & 10,080 & 780 & \end{array}$

For the purpose of these example calculations, it will also be assumed that gasoline costs 80 cents/gallon and LPG costs 45 cents per actual LPG gallon. For each vehicle, the total propane cost (TPC) is:

$$
\mathrm{TPC}_{\# 1}=\mathrm{TPU} * \mathrm{SPC}=0 * \$ .45=\$ 0.00
$$




$$
\begin{gathered}
\mathrm{TPC}_{\# 2}=\mathrm{TPU} * \mathrm{SPC}=1000 * \$ .45=\$ 450.00 \\
\mathrm{TPC}_{\# 3}=\mathrm{TPU} * \mathrm{SPC}=780 * \$ .45=\$ 351.00
\end{gathered}
$$

The total gasoline cost (TGC) is:

$$
\begin{aligned}
\mathrm{TGC}_{\# 1}=\mathrm{TGU} * \mathrm{SGC}=800 * \$ .80 & =\$ 640.00 \\
\mathrm{TGC}_{\# 2}=\mathrm{TGU} * \mathrm{SGC}=0 * \$ .80 & =\$ 0.00 \\
\mathrm{TGC}_{\# 3}=\mathrm{TGU} * \mathrm{SGC}=220 * \$ .80 & =\$ 176.00
\end{aligned}
$$

The fuel operating cost is:

$$
\begin{gathered}
\mathrm{FOC}_{\# 1}=(\mathrm{TPC}+\mathrm{TGC}) / \mathrm{TMD}=(\$ 0+\$ 640) / 10,160=6.30 \phi / \mathrm{mile} \\
\mathrm{FOC}_{\# 2}=(\mathrm{TPC}+\mathrm{TGC}) / \mathrm{TMD}=(\$ 450+\$ 0) / 9,338=4.82 \phi / \mathrm{mile} \\
\mathrm{FOC}_{\# 3}=(\mathrm{TPC}+\mathrm{TGC}) / \mathrm{TMD}=(\$ 351+\$ 176) / 10,080=5.23 \notin / \mathrm{mile}
\end{gathered}
$$

The percent $\mathrm{LPG}$ use (\%LPG) is:

$$
\begin{gathered}
\% \mathrm{LPG}_{\# 1}=\mathrm{TPU} /(\mathrm{TPU}+\mathrm{TGU})=100 *[0 /(0+800)]=0.00 \% \\
\% \mathrm{LPG}_{\# 2}=\mathrm{TPU} /(\mathrm{TPU}+\mathrm{TGU})=100 *[1000 /(1000+0)]=100.00 \% \\
\% \mathrm{LPG}_{\# 3}=\mathrm{TPU} /(\mathrm{TPU}+\mathrm{TGU})=100 *[780 /(780+220)]=78.00 \%
\end{gathered}
$$

The combined fuel economy (CFE) is:

$$
\begin{aligned}
& \mathrm{CFE}_{\# 1}= \frac{\mathrm{TMD}}{(\mathrm{TPU} / 1.36)+\mathrm{TGU}}=\frac{10,160}{(0 / 1.36)+800}=12.7 \mathrm{mpegg}=12.7 \mathrm{mi} / \mathrm{gal}_{\text {gasoline }} \\
& \mathrm{CFE}_{\# 2}=\frac{\mathrm{TMD}}{(\mathrm{TPU} / 1.36)+\mathrm{TGU}}=\frac{9,338}{(1000 / 1.36)+0}=12.7 \mathrm{mpegg} \\
& \mathrm{CFE}_{\# 3}=\frac{\mathrm{TMD}}{(\mathrm{TPU} / 1.36)+\mathrm{TGU}}=\frac{10,080}{(780 / 1.36)+220}=12.7 \mathrm{mpegg}
\end{aligned}
$$




\section{Appendix C: \\ Discussion of Statistics Related to Fuel Use}

The statistics for the factors that are related to fuel use are discussed in this appendix. The fuel economy is discussed first, and includes a discussion of the meanings and uses of the statistical parameters.

\section{Fuel Economy}

Table C-1a presents the fuel economy statistics for the bi-fuel vehicles as determined using the four techniques discussed in Appendix B. Table C-1b presents the fuel economy statistics for the gasoline-only vehicles. Each of these tables will be discussed individually before the results for the bi-fuel vehicles are compared to those for the gasoline-only vehicles.

Table C-1a. Fuel Economy for the Bi-Fuel Vehicles in the Test Fleet

\begin{tabular}{|c|c|c|c|c|c|}
\hline & & \multicolumn{4}{|c|}{ bi-fuel vehicles } \\
\hline & & \multicolumn{2}{|c|}{ from logs } & \multicolumn{2}{|c|}{ from database } \\
\hline & & CFE & CIFE & CFE' & CIFE' \\
\hline & & $\begin{array}{c}\text { Combined } \\
\text { Fuel } \\
\text { Economy }\end{array}$ & $\begin{array}{l}\text { Avg. CIFE } \\
\text { excl. outliers }\end{array}$ & $\begin{array}{c}\text { Combined } \\
\text { Fuel } \\
\text { Economy }\end{array}$ & $\begin{array}{l}\text { Avg. CIFE } \\
\text { excl. outliers }\end{array}$ \\
\hline & & [mpegg] & [mpegg] & [mpegg] & [mpegg] \\
\hline \multicolumn{2}{|c|}{ No. of Data Points } & 31 & 31 & 31 & 31 \\
\hline \multicolumn{2}{|c|}{ Calculated Mean } & 12.50 & 12.75 & 12.35 & 12.68 \\
\hline \multirow{2}{*}{$\begin{array}{l}95 \% \text { Conf. Interval } \\
\text { for the True Mean }\end{array}$} & Lower Bound & 11.82 & 12.17 & 11.84 & 12.06 \\
\hline & Upper Bound & 13.18 & 13.34 & 12.85 & 13.29 \\
\hline \multicolumn{2}{|c|}{ Coeff. of Variability (\%) } & 14.8 & 12.5 & 11.3 & 13.2 \\
\hline
\end{tabular}

In Table C-1a, the calculated mean for the combined fuel economy of the bi-fuel vehicles, in miles per equivalent gallon of gasoline, is almost the same for the two separate calculations applied to each of the two databases. However, there is no fundamental physical reason to expect any difference in these four results. One of the factors that complicates the determination of the average fuel economy is that each vehicle had a different duty cycle. The duty cycle, or driving schedule, has a strong effect on the fuel economy (e.g., the difference between the urban and highway fuel economy of any given vehicle). In Table $\mathrm{C}-1 \mathrm{a}$, this effect is quantified via the Coefficient of Variability of the fuel economy. The $\mathrm{CoV}$ is the standard deviation normalized by the mean, and is between $\sim 11 \%$ and $\sim 15 \%$ for these bi-fuel vehicles. The major reason that the four calculations do not yield precisely identical averages is that the statistical basis for the calculations is relatively small. Statistics can be used to examine the distribution of fuel economies from the individual observations to determine-with $95 \%$ confidence - the range of fuel economies in which the true mean must occur. For example, the long-term data from the $\log$ forms indicates that the true mean for the fuel economy lies in the range of 11.82-13.18 mpegg with 95\% confidence. Given the four different statistical analyses for the combined fuel economy of the bi-fuel vehicles, the overlaps in the $95 \%$ confidence intervals can be used to determine that the true mean must lie within the range of 12.17-12.85 mpegg. The fact that the four values for the calculated mean are all within this confidence interval means that it cannot be 
stated with 95\% confidence that these four means are statistically different. This, of course, is the expected result - the four different methods for calculating the combined fuel economy should not yield different answers. Because the database records are complete whereas the $\log$ form records have some missing data (see Appendix A), and because high or low outliers have been excluded in the calculation of the combined incremental fuel economy (as explained in Appendix B), it is estimated that the bi-fuel vehicles have a combined fuel economy of $\sim 12.7$ mpegg.

Table C-1b. Fuel Economy for the Gasoline-Only Vehicles in the Test Fleet

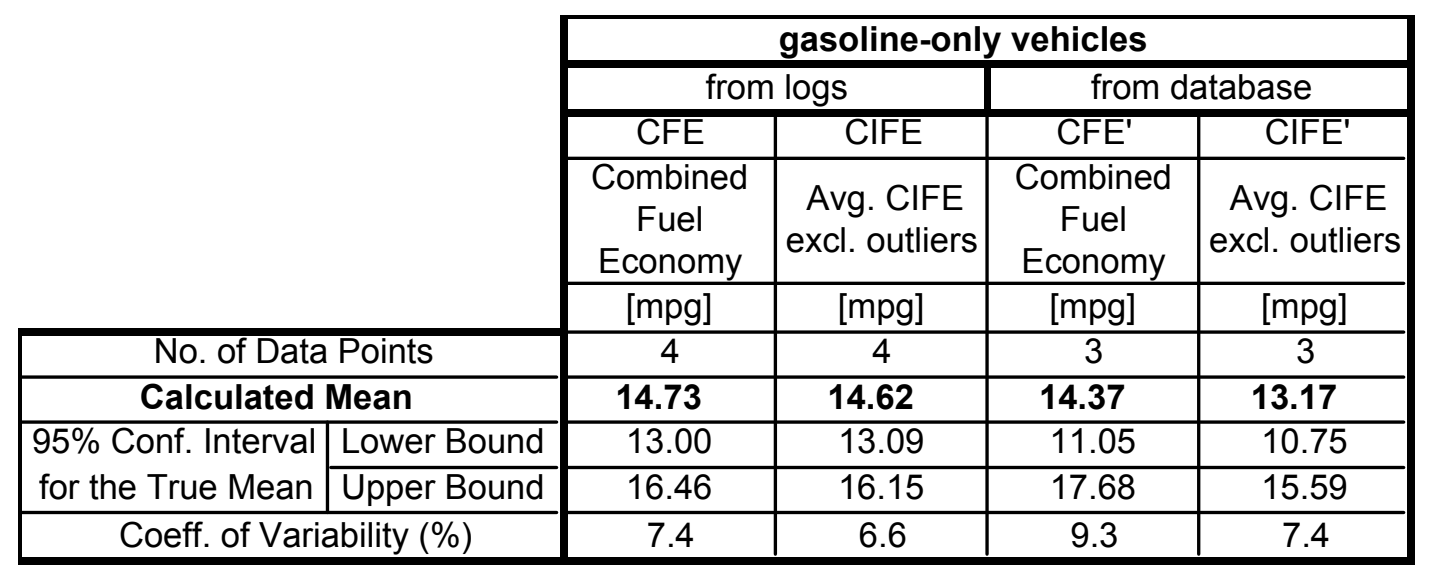

Table $\mathrm{C}-1 \mathrm{~b}$ presents the statistics for the fuel economy of the gasoline-only vehicles. In this case, the size of the statistical sample is an order of magnitude smaller than for the bi-fuel vehicles. The four methods for calculating the fuel economy for the gasoline-only vehicles yield means that range from $13.17 \mathrm{mpg}$ to $14.73 \mathrm{mpg}$ (11.8\% higher). However, the $95 \%$ confidence intervals for where the true mean lies encompass all four of these means. In other words, it cannot be said with at least $95 \%$ confidence that these four measures yield statistically different results. Additionally, the results obtained by analyzing the log form data for the gasoline-only vehicles are less reliable than those from the database records are for two reasons. Most importantly, several months of log form data are missing for one of the gasoline-only vehicles. Also, the $\log$ form data includes the gasoline-only vehicle retained by UT whereas the database records do not. This vehicle was not in daily service for TxDOT and thus had a different duty cycle. In fact, it had the fourth highest fuel economy among all 35 of the test vehicles. Therefore, the database records are both more complete and more representative of the gasolineonly vehicles in TxDOT service. Combining the 95\% confidence intervals for the database statistics indicates that the true mean for the fuel economy of the gasoline-only vehicles lies between $11.05 \mathrm{mpg}$ and $15.59 \mathrm{mpg}$. This encompasses all four means calculated for the bi-fuel vehicles. Thus, it cannot be stated with $95 \%$ confidence that the fuel economy of the gasolineonly vehicles is statistically different from the gasoline-energy-equivalent fuel economy of the bi-fuel vehicles ( 12.7 mpegg). This result is also expected based upon prior research (Matthews et al., 1996; Chiu and Matthews, 1996; Wu et al., 1996, 1998a) as verified by results from the present study (Table 2). 


\section{Percent LPG Used}

Table C-2 presents the statistics regarding the percent use of LPG. Data from both the vehicle operation log forms and the TxDOT database were used to generate the results that are summarized in Table C-2. The means from these two data sets are not statistically different because of the broad $95 \%$ confidence intervals for the value of the true mean. From these results it is estimated that the bi-fuel vehicles in the test fleet average $\sim 78 \%$ use of LPG.

Table C-2. Summary Statistics for the Percent LPG Used

\begin{tabular}{|c|c|c|c|}
\hline & from logs & from database \\
\hline & & $\%$ LPG & \%LPG' \\
\hline & & actual gallons & actual gallons \\
\hline \multicolumn{2}{|c|}{ No. of Data Points } & 31 & 31 \\
\hline \multicolumn{2}{|c|}{ Calculated Mean } & 80.13 & 76.84 \\
\hline \multirow{2}{*}{$\begin{array}{l}95 \% \text { Conf. Interval } \\
\text { for the True Mean }\end{array}$} & Lower Bound & 75.08 & 71.48 \\
\hline & Upper Bound & 85.18 & 82.19 \\
\hline \multicolumn{2}{|c|}{ Coeff. of Variability (\%) } & 17.2 & 19.0 \\
\hline
\end{tabular}

\section{Gasoline and LPG Purchase Prices}

The average prices for LPG and gasoline shown in Table C-3 were obtained from monthly average purchase prices provided by TxDOT for a 16-month period during this project. For LPG, average monthly prices were obtained from both the Houston and Corpus Christi districts since each has an independent contract for LPG. The $\sim \$ 0.80$ per gallon average for gasoline reflects both the discount for bulk purchase and the fact that state agencies do not pay the federal tax on gasoline. Here, it should again be noted that the gasoline price includes state tax paid at the pump whereas the LPG price does not. Instead, the state "road tax" for LPG is paid via an annual tax on the alternative fuels, as discussed in the body of this report. The mean gasoline price was 79.79 cents/gallon and that for LPG (averaging over both Houston and Corpus) was 55.64 cents per actual LPG gallon. These two means are statistically different because the $95 \%$ confidence intervals do not overlap. The mean price of LPG in the Houston district was 49.52 cents per actual LPG gallon (67.35 cents per equivalent gasoline gallon) and that for the Corpus district was 61.75 cents per actual LPG gallon (83.98 cents per equivalent gasoline gallon).

Table C-3. Average LPG and Gasoline Prices for the 34 TxDOT Vehicles

\begin{tabular}{|c|c|c|c|c|c|}
\hline & $\begin{array}{l}\text { Gasoline } \\
\text { price }\end{array}$ & $\begin{array}{c}\text { Corpus } \\
\text { LPG price }\end{array}$ & $\begin{array}{l}\text { Houston } \\
\text { LPG price }\end{array}$ & $\begin{array}{l}\text { avg. LPG } \\
\text { price }\end{array}$ \\
\hline & & (cents/gal) & (cents/gal) & (cents/gal) & (cents/gal) \\
\hline \multicolumn{2}{|c|}{ No. of Data Points } & 16 & 16 & 16 & 32 \\
\hline \multicolumn{2}{|c|}{ Calculated Mean } & 79.79 & 61.75 & 49.52 & 55.64 \\
\hline \multirow{2}{*}{$\begin{array}{l}95 \% \text { Conf. Interval } \\
\text { for the True Mean }\end{array}$} & Lower Bound & 76.01 & 58.90 & 46.67 & 52.70 \\
\hline & Upper Bound & 83.58 & 64.60 & 52.37 & 58.57 \\
\hline \multicolumn{2}{|c|}{ Coeff. of Variability (\%) } & 8.90 & 8.66 & 10.80 & 14.64 \\
\hline
\end{tabular}




\section{Fuel Operating Costs}

Table C-4 provides the results for the fuel operating cost. Only the results from the database records are shown because these records were complete whereas some of the log form data was missing. The gasoline-only vehicle retained by UT has a log form but is not in the TxDOT database. Because this vehicle was not in daily service for TxDOT, the fuel operating cost from the database records is the better indicator for the TxDOT fleet. Comparison of the raw means indicates that the fuel operating cost for the gasoline-only vehicles is lower than that for the bifuel vehicles, including those in Houston that purchase LPG at 12.44 cents per equivalent gallon cheaper than gasoline. This result is caused by the very small statistical basis for the gasolineonly vehicles. The small basis for the gasoline-only vehicles is reflected by the broad $95 \%$ confidence interval for the value of the true mean: $4-7$ cents $/$ mile. Because the $95 \%$ confidence interval for the fuel operating cost of the gasoline-only vehicles overlaps the means for the bifuel vehicles, it cannot be said with $95 \%$ confidence that the fuel operating cost is different for the gasoline-only and bi-fuel vehicles. Because the number of the gasoline-only vehicles is an order of magnitude smaller than for the bi-fuel vehicles, differences in the duty cycle from one vehicle to the next have a much stronger influence on the fuel economy for the gasoline-only vehicles than for the bi-fuel vehicles. This is precisely why this uncontrolled variable (fuel economy) has been factored out in the discussions in the body of the report.

Table C-4. Summary Statistics for the Fuel Operating Cost (from the database records)

\begin{tabular}{|c|c|c|c|c|c|}
\hline & $\begin{array}{l}\text { all bi-fuel } \\
\text { vehicles }\end{array}$ & $\begin{array}{c}\text { Corpus } \\
\text { bi-fuel } \\
\text { vehicles }\end{array}$ & $\begin{array}{c}\text { Houston } \\
\text { bi-fuel } \\
\text { vehicles }\end{array}$ & $\begin{array}{l}\text { gasoline } \\
\text { only } \\
\text { vehicles }\end{array}$ \\
\hline & & $\begin{array}{c}\text { fuel } \\
\text { operating } \\
\text { cost }\end{array}$ & $\begin{array}{c}\text { fuel } \\
\text { operating } \\
\text { cost }\end{array}$ & $\begin{array}{c}\text { fuel } \\
\text { operating } \\
\text { cost }\end{array}$ & $\begin{array}{c}\text { fuel } \\
\text { operating } \\
\text { cost }\end{array}$ \\
\hline & & (cents/mile) & (cents/mile) & (cents/mile) & (cents/mile) \\
\hline \multicolumn{2}{|c|}{ No. of Data Points } & 31 & 16 & 15 & 3 \\
\hline \multicolumn{2}{|c|}{ Calculated Mean } & 6.27 & 6.52 & 6.00 & 5.55 \\
\hline \multirow{2}{*}{$\begin{array}{l}95 \% \text { Conf. Interval } \\
\text { for True Mean }\end{array}$} & Lower Bound & 6.00 & 6.13 & 5.66 & 4.04 \\
\hline & Upper Bound & 6.53 & 6.91 & 6.33 & 7.07 \\
\hline \multicolumn{2}{|c|}{ Coeff. of Variability (\%) } & 11.4 & 11.3 & 10.0 & 11.0 \\
\hline
\end{tabular}


Appendix D:

Detailed Maintenance and Repair Data and Cost Summaries 
Table D.1. Scheduled Maintenance Cost Summary by Vehicle

\begin{tabular}{|c|c|c|c|c|c|c|c|}
\hline \multicolumn{8}{|c|}{ scheduled maintenance } \\
\hline $\begin{array}{c}\text { TxDOT } \\
\text { Eqpt. } \\
\text { No. }\end{array}$ & type & $\begin{array}{c}\text { miles driven in } \\
16 \text { months } \\
\text { (database) }\end{array}$ & $\begin{array}{c}\text { Scheduled } \\
\text { maintenance parts } \\
\text { cost }[\$]\end{array}$ & $\begin{array}{c}\text { Scheduled } \\
\text { maintenance labor } \\
\text { cost }[\$]\end{array}$ & $\begin{array}{c}\text { Scheduled } \\
\text { maintenance other } \\
\text { cost }[\$]\end{array}$ & $\begin{array}{c}\text { Total Scheduled } \\
\text { maintenance cost } \\
{[\$]}\end{array}$ & $\begin{array}{c}\text { Total scheduled } \\
\text { maintenance } \\
\text { operating cost } \\
\text { [cents } / \mathrm{mi}]\end{array}$ \\
\hline $03556 \mathrm{G}$ & bi-fuel & 24066.0 & 52.50 & 150.00 & 12.00 & 214.50 & 0.89 \\
\hline $03558 \mathrm{G}$ & bi-fuel & 30523.0 & 78.75 & 215.50 & 18.00 & 312.25 & 1.02 \\
\hline $03562 \mathrm{G}$ & bi-fuel & 38438.0 & 105.00 & 300.00 & 24.00 & 429.00 & 1.12 \\
\hline $03563 \mathrm{G}$ & bi-fuel & 12405.0 & 8.75 & 50.00 & 2.00 & 60.75 & 0.49 \\
\hline $03570 \mathrm{G}$ & bi-fuel & 33208.0 & 61.25 & 175.00 & 14.00 & 250.25 & 0.75 \\
\hline $03574 \mathrm{G}$ & bi-fuel & 24798.0 & 37.00 & 100.00 & 6.50 & 143.50 & 0.58 \\
\hline $03575 \mathrm{G}$ & bi-fuel & 14221.0 & 43.75 & 125.00 & 10.00 & 178.75 & 1.26 \\
\hline $03577 \mathrm{G}$ & bi-fuel & 18512.0 & 35.00 & 100.00 & 8.00 & 143.00 & 0.77 \\
\hline $03578 \mathrm{G}$ & bi-fuel & 15551.0 & 17.50 & 50.00 & 4.00 & 71.50 & 0.46 \\
\hline $03579 \mathrm{G}$ & bi-fuel & 28440.0 & 52.50 & 150.00 & 12.00 & 214.50 & 0.75 \\
\hline $03625 \mathrm{G}$ & \begin{tabular}{|l|} 
bi-fuel \\
\end{tabular} & 35726.0 & 78.75 & 225.00 & 18.00 & 321.75 & 0.90 \\
\hline $03626 \mathrm{G}$ & bi-fuel & 52514.0 & 105.00 & 327.75 & 24.00 & 456.75 & 0.87 \\
\hline $05414 \mathrm{~F}$ & bi-fuel & 16012.0 & 36.25 & 86.95 & 6.00 & 129.20 & 0.81 \\
\hline $05415 \mathrm{~F}$ & bi-fuel & 25953.0 & 61.25 & 175.00 & 14.00 & 250.25 & 0.96 \\
\hline $05418 \mathrm{~F}$ & bi-fuel & 9294.0 & 17.50 & 50.00 & 4.00 & 71.50 & 0.77 \\
\hline $05419 \mathrm{~F}$ & bi-fuel & 32774.0 & 61.25 & 175.00 & 14.00 & 250.25 & 0.76 \\
\hline $03644 \mathrm{G}$ & bi-fuel & 12714.0 & 22.00 & 16.00 & 4.00 & 42.00 & 0.33 \\
\hline $03649 \mathrm{G}$ & bi-fuel & 13284.0 & 41.75 & 49.00 & 8.00 & 98.75 & 0.74 \\
\hline $03651 \mathrm{G}$ & bi-fuel & 13563.0 & 44.00 & 32.00 & 8.00 & 84.00 & 0.62 \\
\hline $03652 \mathrm{G}$ & bi-fuel & 11991.0 & 44.00 & 32.00 & 8.00 & 84.00 & 0.70 \\
\hline $03655 \mathrm{G}$ & bi-fuel & 5361.0 & 22.00 & 16.00 & 4.00 & 42.00 & 0.78 \\
\hline $05971 \mathrm{~F}$ & bi-fuel & 11325.0 & 33.00 & 24.00 & 6.00 & 63.00 & 0.56 \\
\hline $05972 \mathrm{~F}$ & bi-fuel & 6934.0 & 22.00 & 16.00 & 4.00 & 42.00 & 0.61 \\
\hline $05974 \mathrm{~F}$ & \begin{tabular}{|l|} 
bi-fuel \\
\end{tabular} & 19979.0 & 77.90 & 79.00 & 12.00 & 168.90 & 0.85 \\
\hline $05975 \mathrm{~F}$ & bi-fuel & 23430.0 & 77.00 & 56.00 & 14.00 & 147.00 & 0.63 \\
\hline $05976 \mathrm{~F}$ & bi-fuel & 16807.0 & 52.00 & 24.00 & 8.00 & 84.00 & 0.50 \\
\hline $05992 \mathrm{~F}$ & bi-fuel & 21494.0 & 77.00 & 56.00 & 14.00 & 147.00 & 0.68 \\
\hline $05994 \mathrm{~F}$ & \begin{tabular}{|l|} 
bi-fuel \\
\end{tabular} & 21269.0 & 66.00 & 48.00 & 12.00 & 126.00 & 0.59 \\
\hline $05995 \mathrm{~F}$ & bi-fuel & 20088.0 & 77.00 & 56.00 & 14.00 & 147.00 & 0.73 \\
\hline $05996 \mathrm{~F}$ & \begin{tabular}{|l|} 
bi-fuel \\
\end{tabular} & 17379.0 & 37.58 & 40.00 & 4.00 & 81.58 & 0.47 \\
\hline 05997F & bi-fuel & 20552.0 & 77.00 & 56.00 & 14.00 & 147.00 & 0.72 \\
\hline UT & gasoline & 32317.4 & 116.07 & 86.99 & 8.00 & 211.06 & 0.65 \\
\hline $04353 \mathrm{G}$ & gasoline & 19379.0 & 66.00 & 48.00 & 12.00 & 126.00 & 0.65 \\
\hline $04354 \mathrm{G}$ & gasoline & 14692.0 & 66.00 & 48.00 & 12.00 & 126.00 & 0.86 \\
\hline $04355 \mathrm{G}$ & gasoline & 38806.0 & 57.00 & 116.00 & 12.00 & 185.00 & 0.48 \\
\hline
\end{tabular}


Table D.2. Repair Cost (Unscheduled maintenance) Summary by Vehicle

\begin{tabular}{|c|c|c|c|c|c|c|}
\hline \multicolumn{7}{|c|}{ overall repair costs (\$) } \\
\hline $\begin{array}{l}\text { TxDOT } \\
\text { Eqpt. No. }\end{array}$ & type & $\begin{array}{l}\text { miles driven in } 16 \\
\text { months (database) }\end{array}$ & $\begin{array}{c}\text { Unscheduled } \\
\text { maintenance parts } \\
\text { cost }[\$]\end{array}$ & $\begin{array}{c}\text { Unscheduled } \\
\text { maintenance labor } \\
\text { cost }[\$]\end{array}$ & $\begin{array}{c}\text { Unscheduled } \\
\text { maintenance other } \\
\text { cost }[\$]\end{array}$ & $\begin{array}{c}\text { Total unscheduled } \\
\text { maintenance cost } \\
{[\$]}\end{array}$ \\
\hline $03556 \mathrm{G}$ & bi-fuel & 24066.0 & 1052.03 & 992.64 & & 2044.67 \\
\hline $03558 \mathrm{G}$ & bi-fuel & 30523.0 & 239.96 & 1347.14 & & 1587.10 \\
\hline $03562 \mathrm{G}$ & bi-fuel & 38438.0 & 310.64 & 97.34 & & 407.98 \\
\hline $03563 \mathrm{G}$ & bi-fuel & 12405.0 & 23.30 & 168.86 & & 192.16 \\
\hline $03570 \mathrm{G}$ & bi-fuel & 33208.0 & 145.07 & 673.04 & & 818.11 \\
\hline 03574G & bi-fuel & 24798.0 & 131.05 & 589.01 & & 720.06 \\
\hline $03575 \mathrm{G}$ & bi-fuel & 14221.0 & 167.68 & 58.80 & & 226.48 \\
\hline $03577 \mathrm{G}$ & bi-fuel & 18512.0 & 464.79 & 580.04 & & 1044.83 \\
\hline 03578G & bi-fuel & 15551.0 & 70.00 & 267.52 & & 337.52 \\
\hline 03579G & bi-fuel & 28440.0 & 303.59 & 309.50 & & 613.09 \\
\hline $03625 \mathrm{G}$ & bi-fuel & 35726.0 & 73.22 & 0.00 & & 73.22 \\
\hline $03626 \mathrm{G}$ & bi-fuel & 52514.0 & 376.42 & 838.46 & 27.22 & 1242.10 \\
\hline $05414 \mathrm{~F}$ & bi-fuel & 16012.0 & 120.94 & 117.84 & & 238.78 \\
\hline $05415 \mathrm{~F}$ & bi-fuel & 25953.0 & 104.61 & 274.54 & & 379.15 \\
\hline $05418 \mathrm{~F}$ & bi-fuel & 9294.0 & & & & 0.00 \\
\hline $05419 \mathrm{~F}$ & bi-fuel & 32774.0 & 1488.65 & 1383.40 & & 2872.05 \\
\hline $03644 \mathrm{G}$ & bi-fuel & 12714.0 & 78.50 & 119.64 & & 198.14 \\
\hline $03649 \mathrm{G}$ & bi-fuel & 13284.0 & & 145.68 & & 145.68 \\
\hline $03651 \mathrm{G}$ & bi-fuel & 13563.0 & & 36.42 & & 36.42 \\
\hline $03652 \mathrm{G}$ & bi-fuel & 11991.0 & & 36.42 & & 36.42 \\
\hline $03655 \mathrm{G}$ & bi-fuel & 5361.0 & & 145.68 & & 145.68 \\
\hline $05971 \mathrm{~F}$ & bi-fuel & 11325.0 & 72.00 & 364.00 & 5.94 & 441.94 \\
\hline $05972 \mathrm{~F}$ & bi-fuel & 6934.0 & & & & 0.00 \\
\hline $05974 \mathrm{~F}$ & bi-fuel & 19979.0 & 1689.54 & 985.54 & & 2675.08 \\
\hline $05975 \mathrm{~F}$ & bi-fuel & 23430.0 & 17.26 & 196.68 & & 213.94 \\
\hline $05976 \mathrm{~F}$ & bi-fuel & 16807.0 & & 218.52 & & 218.52 \\
\hline $05992 \mathrm{~F}$ & bi-fuel & 21494.0 & & & & 0.00 \\
\hline $05994 \mathrm{~F}$ & bi-fuel & 21269.0 & & 36.42 & & 36.42 \\
\hline $05995 \mathrm{~F}$ & bi-fuel & 20088.0 & & 97.84 & & 97.84 \\
\hline $05996 \mathrm{~F}$ & bi-fuel & 17379.0 & 864.45 & 942.39 & 40.00 & 1846.84 \\
\hline $05997 \mathrm{~F}$ & bi-fuel & 20552.0 & 65.56 & 107.90 & & 173.46 \\
\hline UT & gasoline & 32317.4 & & 10.00 & & 10.00 \\
\hline $04353 \mathrm{G}$ & gasoline & 19379.0 & 34.52 & 26.00 & & 60.52 \\
\hline 04354G & gasoline & 14692.0 & 216.15 & 132.84 & & 348.99 \\
\hline $04355 \mathrm{G}$ & gasoline & 38806.0 & & & & 0.00 \\
\hline
\end{tabular}


Table D.3. Repair Cost Summary in Cents per Mile (by vehicle)

\begin{tabular}{|c|c|c|c|c|c|c|}
\hline \multicolumn{7}{|c|}{ overall repair operating costs (cents/mile) } \\
\hline $\begin{array}{l}\text { TxDOT } \\
\text { Eqpt. No. }\end{array}$ & type & $\begin{array}{l}\text { miles driven in } 16 \\
\text { months (database) }\end{array}$ & $\begin{array}{c}\text { Unscheduled } \\
\text { maintenance } \\
\text { operating parts costs } \\
\text { [cents } / \mathrm{mi}]\end{array}$ & \begin{tabular}{|c|} 
Unscheduled \\
maintenance \\
operating labor costs \\
[cents $/$ mi]
\end{tabular} & \begin{tabular}{|c|} 
Unscheduled \\
maintenance \\
operating other costs \\
[cents $/ \mathrm{mi}]$
\end{tabular} & $\begin{array}{l}\text { Total unscheduled } \\
\text { maintenance } \\
\text { operating costs } \\
\text { (cents/mile) }\end{array}$ \\
\hline 03556G & bi-fuel & 24066.0 & 4.37 & 4.12 & 0.00 & 8.50 \\
\hline 03558G & bi-fuel & 30523.0 & 0.79 & 4.41 & 0.00 & 5.20 \\
\hline $03562 \mathrm{G}$ & bi-fuel & 38438.0 & 0.81 & 0.25 & 0.00 & 1.06 \\
\hline $03563 \mathrm{G}$ & bi-fuel & 12405.0 & 0.19 & 1.36 & 0.00 & 1.55 \\
\hline 03570G & bi-fuel & 33208.0 & 0.44 & 2.03 & 0.00 & 2.46 \\
\hline $03574 \mathrm{G}$ & bi-fuel & 24798.0 & 0.53 & 2.38 & 0.00 & 2.90 \\
\hline 03575G & bi-fuel & 14221.0 & 1.18 & 0.41 & 0.00 & 1.59 \\
\hline 03577G & bi-fuel & 18512.0 & 2.51 & 3.13 & 0.00 & 5.64 \\
\hline 03578G & bi-fuel & 15551.0 & 0.45 & 1.72 & 0.00 & 2.17 \\
\hline 03579G & bi-fuel & 28440.0 & 1.07 & 1.09 & 0.00 & 2.16 \\
\hline $03625 \mathrm{G}$ & bi-fuel & 35726.0 & 0.20 & 0.00 & 0.00 & 0.20 \\
\hline $03626 \mathrm{G}$ & bi-fuel & 52514.0 & 0.72 & 1.60 & 0.05 & 2.37 \\
\hline $05414 \mathrm{~F}$ & bi-fuel & 16012.0 & 0.76 & 0.74 & 0.00 & 1.49 \\
\hline $05415 \mathrm{~F}$ & bi-fuel & 25953.0 & 0.40 & 1.06 & 0.00 & 1.46 \\
\hline $05418 \mathrm{~F}$ & bi-fuel & 9294.0 & 0.00 & 0.00 & 0.00 & 0.00 \\
\hline $05419 \mathrm{~F}$ & bi-fuel & 32774.0 & 4.54 & 4.22 & 0.00 & 8.76 \\
\hline $03644 \mathrm{G}$ & bi-fuel & 12714.0 & 0.62 & 0.94 & 0.00 & 1.56 \\
\hline 03649G & bi-fuel & 13284.0 & 0.00 & 1.10 & 0.00 & 1.10 \\
\hline $03651 \mathrm{G}$ & bi-fuel & 13563.0 & 0.00 & 0.27 & 0.00 & 0.27 \\
\hline $03652 \mathrm{G}$ & bi-fuel & 11991.0 & 0.00 & 0.30 & 0.00 & 0.30 \\
\hline $03655 \mathrm{G}$ & bi-fuel & 5361.0 & 0.00 & 2.72 & 0.00 & 2.72 \\
\hline $05971 \mathrm{~F}$ & bi-fuel & 11325.0 & 0.64 & 3.21 & 0.05 & 3.90 \\
\hline $05972 \mathrm{~F}$ & bi-fuel & 6934.0 & 0.00 & 0.00 & 0.00 & 0.00 \\
\hline $05974 \mathrm{~F}$ & bi-fuel & 19979.0 & 8.46 & 4.93 & 0.00 & 13.39 \\
\hline $05975 \mathrm{~F}$ & bi-fuel & 23430.0 & 0.07 & 0.84 & 0.00 & 0.91 \\
\hline $05976 \mathrm{~F}$ & bi-fuel & 16807.0 & 0.00 & 1.30 & 0.00 & 1.30 \\
\hline $05992 \mathrm{~F}$ & bi-fuel & 21494.0 & 0.00 & 0.00 & 0.00 & 0.00 \\
\hline $05994 \mathrm{~F}$ & bi-fuel & 21269.0 & 0.00 & 0.17 & 0.00 & 0.17 \\
\hline $05995 \mathrm{~F}$ & bi-fuel & 20088.0 & 0.00 & 0.49 & 0.00 & 0.49 \\
\hline $05996 \mathrm{~F}$ & bi-fuel & 17379.0 & 4.97 & 5.42 & 0.23 & 10.63 \\
\hline $05997 \mathrm{~F}$ & bi-fuel & 20552.0 & 0.32 & 0.53 & 0.00 & 0.84 \\
\hline UT & gasoline & 32317.4 & 0.00 & 0.03 & 0.00 & 0.03 \\
\hline $04353 \mathrm{G}$ & gasoline & 19379.0 & 0.18 & 0.13 & 0.00 & 0.31 \\
\hline $04354 \mathrm{G}$ & gasoline & 14692.0 & 1.47 & 0.90 & 0.00 & 2.38 \\
\hline $04355 \mathrm{G}$ & gasoline & 38806.0 & 0.00 & 0.00 & 0.00 & 0.00 \\
\hline
\end{tabular}


Table D.4. LPG-related Repair Cost Summary (by vehicle)

\begin{tabular}{|c|c|c|c|c|c|c|}
\hline \multicolumn{7}{|c|}{ LPG-related repair costs (\$) } \\
\hline $\begin{array}{c}\text { TxDOT } \\
\text { Eqpt. No. }\end{array}$ & type & $\begin{array}{l}\text { miles driven in } 16 \\
\text { months (database) }\end{array}$ & $\begin{array}{c}\text { LPG related repair } \\
\text { parts costs }[\$]\end{array}$ & $\begin{array}{l}\text { LPG related repair } \\
\text { labor costs [\$] }\end{array}$ & $\begin{array}{l}\text { LPG related repair } \\
\text { other costs [\$] }\end{array}$ & $\begin{array}{l}\text { LPG related repair } \\
\text { total costs }[\$]\end{array}$ \\
\hline 03556G & bi-fuel & 24066.0 & 940.49 & 666.68 & & 1607.17 \\
\hline $03558 \mathrm{G}$ & bi-fuel & 30523.0 & 144.38 & 39.20 & & 183.58 \\
\hline $03562 \mathrm{G}$ & $\overline{\text { bi-fuel }}$ & 38438.0 & 293.38 & 72.84 & & 366.22 \\
\hline 03563G & bi-fuel & 12405.0 & 23.30 & 56.02 & & 79.32 \\
\hline 03570G & bi-fuel & 33208.0 & 145.07 & 673.04 & & 818.11 \\
\hline 03574G & $\overline{\text { bi-fuel }}$ & 24798.0 & & & & \\
\hline 03575G & bi-fuel & 14221.0 & 167.68 & 58.80 & & 226.48 \\
\hline $03577 \mathrm{G}$ & bi-fuel & 18512.0 & & & & \\
\hline 03578G & $\overline{\text { bi-fuel }}$ & 15551.0 & & 218.52 & & 218.52 \\
\hline 03579G & bi-fuel & 28440.0 & 286.33 & 207.26 & & 493.59 \\
\hline $03625 \mathrm{G}$ & bi-fuel & 35726.0 & & & & \\
\hline $03626 \mathrm{G}$ & bi-fuel & 52514.0 & 213.82 & 490.02 & 27.22 & 731.06 \\
\hline $05414 \mathrm{~F}$ & bi-fuel & 16012.0 & & & & \\
\hline $05415 \mathrm{~F}$ & bi-fuel & 25953.0 & & & & \\
\hline $05418 \mathrm{~F}$ & $\overline{\text { bi-fuel }}$ & 9294.0 & & & & \\
\hline 05419F & bi-fuel & 32774.0 & 144.38 & 184.88 & & 329.26 \\
\hline $03644 \mathrm{G}$ & bi-fuel & 12714.0 & & & & \\
\hline 03649G & bi-fuel & 13284.0 & & & & \\
\hline $03651 \mathrm{G}$ & $\overline{\text { bi-fuel }}$ & 13563.0 & & & & \\
\hline $03652 \mathrm{G}$ & bi-fuel & 11991.0 & & & & \\
\hline $03655 \mathrm{G}$ & bi-fuel & 5361.0 & & & & \\
\hline $05971 \mathrm{~F}$ & bi-fuel & 11325.0 & & & & \\
\hline $05972 \mathrm{~F}$ & bi-fuel & 6934.0 & & & & \\
\hline $05974 \mathrm{~F}$ & bi-fuel & 19979.0 & 475.09 & 385.54 & & 860.63 \\
\hline $05975 \mathrm{~F}$ & $\overline{\text { bi-fuel }}$ & 23430.0 & & & & \\
\hline $05976 \mathrm{~F}$ & $\overline{\text { bi-fuel }}$ & 16807.0 & & 145.68 & & 145.68 \\
\hline $05992 \mathrm{~F}$ & bi-fuel & 21494.0 & & & & \\
\hline 05994F & bi-fuel & 21269.0 & & & & \\
\hline $05995 \mathrm{~F}$ & bi-fuel & 20088.0 & & & & \\
\hline $05996 \mathrm{~F}$ & bi-fuel & 17379.0 & & & & \\
\hline $05997 \mathrm{~F}$ & bi-fuel & 20552.0 & 23.30 & & & 23.30 \\
\hline
\end{tabular}


Table D.5. LPG-related Repair Cost Summary in Cents per Mile (by vehicle)

\begin{tabular}{|c|c|c|c|c|c|c|}
\hline \multicolumn{7}{|c|}{ LPG-related repair operating costs (cents/mile) } \\
\hline $\begin{array}{l}\text { TxDOT } \\
\text { Eqpt. No. }\end{array}$ & type & $\begin{array}{l}\text { miles driven in } 16 \\
\text { months (database) }\end{array}$ & $\begin{array}{c}\text { LPG related repair } \\
\text { operating parts costs } \\
\text { [cents } / \mathrm{mi}]\end{array}$ & $\begin{array}{l}\text { LPG related repair } \\
\text { operating labor costs } \\
\text { [cents/mi] }\end{array}$ & $\begin{array}{l}\text { LPG related repair } \\
\text { operating other costs } \\
\text { [cents/mi] }\end{array}$ & $\begin{array}{l}\text { LPG related repair } \\
\text { operating total costs } \\
\text { [cents/mi] }\end{array}$ \\
\hline $03556 \mathrm{G}$ & bi-fuel & 24066.0 & 3.91 & 2.77 & 0.00 & 6.68 \\
\hline 03558G & bi-fuel & 30523.0 & 0.47 & 0.13 & 0.00 & 0.60 \\
\hline $03562 \mathrm{G}$ & bi-fuel & 38438.0 & 0.76 & 0.19 & 0.00 & 0.95 \\
\hline 03563G & bi-fuel & 12405.0 & 0.19 & 0.45 & 0.00 & 0.64 \\
\hline 03570G & bi-fuel & 33208.0 & 0.44 & 2.03 & 0.00 & 2.46 \\
\hline $03574 \mathrm{G}$ & bi-fuel & 24798.0 & & & & \\
\hline $03575 \mathrm{G}$ & bi-fuel & 14221.0 & 1.18 & 0.41 & 0.00 & 1.59 \\
\hline 03577G & bi-fuel & 18512.0 & & & & \\
\hline 03578G & bi-fuel & 15551.0 & 0.00 & 1.41 & 0.00 & 1.41 \\
\hline 03579G & bi-fuel & 28440.0 & 1.01 & 0.73 & 0.00 & 1.74 \\
\hline $03625 \mathrm{G}$ & bi-fuel & 35726.0 & & & & \\
\hline $03626 \mathrm{G}$ & bi-fuel & 52514.0 & 0.41 & 0.93 & 0.05 & 1.39 \\
\hline $05414 \mathrm{~F}$ & bi-fuel & 16012.0 & & & & \\
\hline $05415 \mathrm{~F}$ & bi-fuel & 25953.0 & & & & \\
\hline $05418 \mathrm{~F}$ & bi-fuel & 9294.0 & & & & \\
\hline $05419 \mathrm{~F}$ & bi-fuel & 32774.0 & 0.44 & 0.56 & 0.00 & 1.00 \\
\hline 03644G & bi-fuel & 12714.0 & & & & \\
\hline 03649G & bi-fuel & 13284.0 & & & & \\
\hline $03651 \mathrm{G}$ & bi-fuel & 13563.0 & & & & \\
\hline $03652 \mathrm{G}$ & bi-fuel & 11991.0 & & & & \\
\hline $03655 \mathrm{G}$ & bi-fuel & 5361.0 & & & & \\
\hline $05971 \mathrm{~F}$ & bi-fuel & 11325.0 & & & & \\
\hline $05972 \mathrm{~F}$ & bi-fuel & 6934.0 & & & & \\
\hline $05974 \mathrm{~F}$ & bi-fuel & 19979.0 & 2.38 & 1.93 & 0.00 & 4.31 \\
\hline $05975 \mathrm{~F}$ & bi-fuel & 23430.0 & & & & \\
\hline $05976 \mathrm{~F}$ & bi-fuel & 16807.0 & 0.00 & 0.87 & 0.00 & 0.87 \\
\hline $05992 \mathrm{~F}$ & bi-fuel & 21494.0 & & & & \\
\hline $05994 \mathrm{~F}$ & bi-fuel & 21269.0 & & & & \\
\hline $05995 \mathrm{~F}$ & bi-fuel & 20088.0 & & & & \\
\hline $05996 \mathrm{~F}$ & bi-fuel & 17379.0 & & & & \\
\hline $05997 \mathrm{~F}$ & bi-fuel & 20552.0 & 0.11 & 0.00 & 0.00 & 0.11 \\
\hline
\end{tabular}


Table D.6. Non-LPG-related Repair Cost Summary (by vehicle)

\begin{tabular}{|c|c|c|c|c|c|c|}
\hline \multicolumn{7}{|c|}{ non-LPG-related repair costs (\$) } \\
\hline $\begin{array}{l}\text { TxDOT } \\
\text { Eqpt. No. }\end{array}$ & type & $\begin{array}{l}\text { miles driven in } 16 \\
\text { months (database) }\end{array}$ & $\begin{array}{l}\text { Non-LPG related } \\
\text { repair parts costs }[\$]\end{array}$ & $\begin{array}{c}\text { Non-LPG related } \\
\text { repair labor costs }[\$]\end{array}$ & $\begin{array}{l}\text { Non-LPG related } \\
\text { repair other costs [\$] }\end{array}$ & $\begin{array}{l}\text { Non-LPG related } \\
\text { repair total costs [\$] }\end{array}$ \\
\hline 03556G & bi-fuel & 24066.0 & 111.54 & 325.96 & & 437.50 \\
\hline 03558G & bi-fuel & 30523.0 & 95.58 & 1307.94 & & 1403.52 \\
\hline $03562 \mathrm{G}$ & bi-fuel & 38438.0 & 17.26 & 24.50 & & 41.76 \\
\hline $03563 \mathrm{G}$ & bi-fuel & 12405.0 & 0.00 & 112.84 & & 112.84 \\
\hline 03570G & bi-fuel & 33208.0 & 0.00 & 0.00 & & 0.00 \\
\hline 03574G & bi-fuel & 24798.0 & 131.05 & 589.01 & & 720.06 \\
\hline $03575 \mathrm{G}$ & bi-fuel & 14221.0 & 0.00 & 0.00 & & 0.00 \\
\hline 03577G & bi-fuel & 18512.0 & 464.79 & 580.04 & & 1044.83 \\
\hline 03578G & bi-fuel & 15551.0 & 70.00 & 49.00 & & 119.00 \\
\hline 03579G & bi-fuel & 28440.0 & 17.26 & 102.24 & & 119.50 \\
\hline $03625 \mathrm{G}$ & bi-fuel & 35726.0 & 73.22 & 0.00 & & 73.22 \\
\hline $03626 \mathrm{G}$ & bi-fuel & 52514.0 & 162.60 & 348.44 & & 511.04 \\
\hline $05414 \mathrm{~F}$ & bi-fuel & 16012.0 & 120.94 & 117.84 & & 238.78 \\
\hline $05415 \mathrm{~F}$ & bi-fuel & 25953.0 & 104.61 & 274.54 & & 379.15 \\
\hline $05418 \mathrm{~F}$ & bi-fuel & 9294.0 & 0.00 & 0.00 & & 0.00 \\
\hline $05419 \mathrm{~F}$ & bi-fuel & 32774.0 & 1344.27 & 1198.52 & & 2542.79 \\
\hline $03644 \mathrm{G}$ & bi-fuel & 12714.0 & 78.50 & 119.64 & & 198.14 \\
\hline 03649G & bi-fuel & 13284.0 & 0.00 & 145.68 & & 145.68 \\
\hline $03651 \mathrm{G}$ & bi-fuel & 13563.0 & 0.00 & 36.42 & & 36.42 \\
\hline $03652 \mathrm{G}$ & bi-fuel & 11991.0 & 0.00 & 36.42 & & 36.42 \\
\hline $03655 \mathrm{G}$ & bi-fuel & 5361.0 & 0.00 & 145.68 & & 145.68 \\
\hline $05971 \mathrm{~F}$ & bi-fuel & 11325.0 & 72.00 & 364.00 & 5.94 & 441.94 \\
\hline $05972 \mathrm{~F}$ & bi-fuel & 6934.0 & 0.00 & 0.00 & & 0.00 \\
\hline $05974 \mathrm{~F}$ & bi-fuel & 19979.0 & 1214.45 & 600.00 & & 1814.45 \\
\hline $05975 \mathrm{~F}$ & bi-fuel & 23430.0 & 17.26 & 196.68 & & 213.94 \\
\hline $05976 \mathrm{~F}$ & bi-fuel & 16807.0 & 0.00 & 72.84 & & 72.84 \\
\hline $05992 \mathrm{~F}$ & bi-fuel & 21494.0 & 0.00 & 0.00 & & 0.00 \\
\hline $05994 \mathrm{~F}$ & bi-fuel & 21269.0 & 0.00 & 36.42 & & 36.42 \\
\hline $05995 \mathrm{~F}$ & bi-fuel & 20088.0 & 0.00 & 97.84 & & 97.84 \\
\hline $05996 \mathrm{~F}$ & bi-fuel & 17379.0 & 864.45 & 942.39 & 40.00 & 1846.84 \\
\hline 05997F & bi-fuel & 20552.0 & 42.26 & 107.90 & & 150.16 \\
\hline UT & gasoline & 32317.4 & 0.00 & 10.00 & & 10.00 \\
\hline $04353 \mathrm{G}$ & gasoline & 19379.0 & 34.52 & 26.00 & & 60.52 \\
\hline $04354 \mathrm{G}$ & gasoline & 14692.0 & 216.15 & 132.84 & & 348.99 \\
\hline 04355G & gasoline & 38806.0 & 0.00 & 0.00 & & 0.00 \\
\hline
\end{tabular}


Table D.7. Non-LPG-related Repair Cost Summary in Cents per Mile (by vehicle)

\begin{tabular}{|c|c|c|c|c|c|c|}
\hline \multicolumn{7}{|c|}{ non-LPG-related repair operating costs (cents/mile) } \\
\hline $\begin{array}{l}\text { TxDOT } \\
\text { Eqpt. No. }\end{array}$ & type & $\begin{array}{l}\text { miles driven in } 16 \\
\text { months (database) }\end{array}$ & $\begin{array}{c}\text { Non-LPG related } \\
\text { repair operating parts } \\
\text { costs [cents/mi] }\end{array}$ & $\begin{array}{c}\text { Non-LPG related } \\
\text { repair operating labor } \\
\text { costs [cents/mi] }\end{array}$ & $\begin{array}{l}\text { Non-LPG related } \\
\text { repair operating other } \\
\text { costs [cents/mi] }\end{array}$ & $\begin{array}{c}\text { Non-LPG related } \\
\text { repair operating tota } \\
\text { costs [cents/mi] }\end{array}$ \\
\hline 03556G & bi-fuel & 24066.0 & 0.46 & 1.35 & 0.00 & 1.82 \\
\hline 03558G & bi-fuel & 30523.0 & 0.31 & 4.29 & 0.00 & 4.60 \\
\hline $03562 \mathrm{G}$ & bi-fuel & 38438.0 & 0.04 & 0.06 & 0.00 & 0.11 \\
\hline 03563G & bi-fuel & 12405.0 & 0.00 & 0.91 & 0.00 & 0.91 \\
\hline 03570G & bi-fuel & 33208.0 & 0.00 & 0.00 & 0.00 & 0.00 \\
\hline 03574G & bi-fuel & 24798.0 & 0.53 & 2.38 & 0.00 & 2.90 \\
\hline 03575G & bi-fuel & 14221.0 & 0.00 & 0.00 & 0.00 & 0.00 \\
\hline 03577G & bi-fuel & 18512.0 & 2.51 & 3.13 & 0.00 & 5.64 \\
\hline 03578G & bi-fuel & 15551.0 & 0.45 & 0.32 & 0.00 & 0.77 \\
\hline 03579G & bi-fuel & 28440.0 & 0.06 & 0.36 & 0.00 & 0.42 \\
\hline $03625 \mathrm{G}$ & bi-fuel & 35726.0 & 0.20 & 0.00 & 0.00 & 0.20 \\
\hline 03626G & bi-fuel & 52514.0 & 0.31 & 0.66 & 0.00 & 0.97 \\
\hline $05414 \mathrm{~F}$ & bi-fuel & 16012.0 & 0.76 & 0.74 & 0.00 & 1.49 \\
\hline $05415 \mathrm{~F}$ & bi-fuel & 25953.0 & 0.40 & 1.06 & 0.00 & 1.46 \\
\hline $05418 \mathrm{~F}$ & bi-fuel & 9294.0 & 0.00 & 0.00 & 0.00 & 0.00 \\
\hline $05419 \mathrm{~F}$ & bi-fuel & 32774.0 & 4.10 & 3.66 & 0.00 & 7.76 \\
\hline 03644G & bi-fuel & 12714.0 & 0.62 & 0.94 & 0.00 & 1.56 \\
\hline 03649G & bi-fuel & 13284.0 & 0.00 & 1.10 & 0.00 & 1.10 \\
\hline $03651 \mathrm{G}$ & bi-fuel & 13563.0 & 0.00 & 0.27 & 0.00 & 0.27 \\
\hline $03652 \mathrm{G}$ & bi-fuel & 11991.0 & 0.00 & 0.30 & 0.00 & 0.30 \\
\hline $03655 \mathrm{G}$ & bi-fuel & 5361.0 & 0.00 & 2.72 & 0.00 & 2.72 \\
\hline $05971 \mathrm{~F}$ & bi-fuel & 11325.0 & 0.64 & 3.21 & 0.05 & 3.90 \\
\hline $05972 \mathrm{~F}$ & bi-fuel & 6934.0 & 0.00 & 0.00 & 0.00 & 0.00 \\
\hline $05974 \mathrm{~F}$ & bi-fuel & 19979.0 & 6.08 & 3.00 & 0.00 & 9.08 \\
\hline $05975 \mathrm{~F}$ & bi-fuel & 23430.0 & 0.07 & 0.84 & 0.00 & 0.91 \\
\hline $05976 \mathrm{~F}$ & bi-fuel & 16807.0 & 0.00 & 0.43 & 0.00 & 0.43 \\
\hline $05992 \mathrm{~F}$ & bi-fuel & 21494.0 & 0.00 & 0.00 & 0.00 & 0.00 \\
\hline $05994 \mathrm{~F}$ & bi-fuel & 21269.0 & 0.00 & 0.17 & 0.00 & 0.17 \\
\hline $05995 \mathrm{~F}$ & bi-fuel & 20088.0 & 0.00 & 0.49 & 0.00 & 0.49 \\
\hline $05996 \mathrm{~F}$ & \begin{tabular}{|l|} 
bi-fuel \\
\end{tabular} & 17379.0 & 4.97 & 5.42 & 0.23 & 10.63 \\
\hline $05997 \mathrm{~F}$ & bi-fuel & 20552.0 & 0.21 & 0.53 & 0.00 & 0.73 \\
\hline UT & gasoline & 32317.4 & 0.00 & 0.03 & 0.00 & 0.03 \\
\hline 04353G & gasoline & 19379.0 & 0.18 & 0.13 & 0.00 & 0.31 \\
\hline 04354G & gasoline & 14692.0 & 1.47 & 0.90 & 0.00 & 2.38 \\
\hline $04355 \mathrm{G}$ & gasoline & 38806.0 & 0.00 & 0.00 & 0.00 & 0.00 \\
\hline
\end{tabular}


Table D.8. Summary of Reliability Rates (by vehicle)

\begin{tabular}{|c|c|c|c|c|c|c|}
\hline \multicolumn{7}{|c|}{ reliability (repair rates) } \\
\hline $\begin{array}{c}\text { TxDOT } \\
\text { Eqpt. No. }\end{array}$ & type & $\begin{array}{l}\text { miles driven in } 16 \\
\text { months (database) }\end{array}$ & $\begin{array}{l}\text { Total repairs in this } \\
16 \text { months }\end{array}$ & $\begin{array}{l}\text { Total LPG related } \\
\text { repairs in this } 16 \\
\text { months }\end{array}$ & $\begin{array}{l}\text { Total repairs } / 5000 \\
\text { miles }\end{array}$ & $\begin{array}{l}\text { Total LPG related } \\
\text { repairs } / 5000 \text { miles }\end{array}$ \\
\hline 03556G & bi-fuel & 24066.0 & 7 & 4 & 1.45 & 0.83 \\
\hline 03558G & bi-fuel & 30523.0 & 7 & 1 & 1.15 & 0.16 \\
\hline $03562 \mathrm{G}$ & bi-fuel & 38438.0 & 2 & 1 & 0.26 & 0.13 \\
\hline 03563G & bi-fuel & 12405.0 & 2 & 1 & 0.81 & 0.40 \\
\hline 03570G & bi-fuel & 33208.0 & 1 & 1 & 0.15 & 0.15 \\
\hline 03574G & bi-fuel & 24798.0 & 5 & & 1.01 & \\
\hline 03575G & bi-fuel & 14221.0 & 1 & 1 & 0.35 & 0.35 \\
\hline 03577G & bi-fuel & 18512.0 & 6 & & 1.62 & \\
\hline 03578G & bi-fuel & 15551.0 & 2 & 1 & 0.64 & 0.32 \\
\hline 03579G & bi-fuel & 28440.0 & 2 & 1 & 0.35 & 0.18 \\
\hline $03625 \mathrm{G}$ & bi-fuel & 35726.0 & 2 & & 0.28 & \\
\hline $03626 \mathrm{G}$ & bi-fuel & 52514.0 & 10 & 1 & 0.95 & 0.10 \\
\hline $05414 \mathrm{~F}$ & bi-fuel & 16012.0 & 3 & & 0.94 & \\
\hline $05415 \mathrm{~F}$ & bi-fuel & 25953.0 & 5 & & 0.96 & \\
\hline $05418 \mathrm{~F}$ & bi-fuel & 9294.0 & & & & \\
\hline $05419 \mathrm{~F}$ & bi-fuel & 32774.0 & 5 & 1 & 0.76 & 0.15 \\
\hline 03644G & bi-fuel & 12714.0 & 2 & & 0.79 & \\
\hline 03649G & bi-fuel & 13284.0 & 3 & & 1.13 & \\
\hline $03651 \mathrm{G}$ & bi-fuel & 13563.0 & 1 & & 0.37 & \\
\hline $03652 \mathrm{G}$ & bi-fuel & 11991.0 & 1 & & 0.42 & \\
\hline $03655 \mathrm{G}$ & bi-fuel & 5361.0 & 2 & & 1.87 & \\
\hline $05971 \mathrm{~F}$ & bi-fuel & 11325.0 & 1 & & 0.44 & \\
\hline $05972 \mathrm{~F}$ & bi-fuel & 6934.0 & & & & \\
\hline $05974 \mathrm{~F}$ & bi-fuel & 19979.0 & 5 & 1 & 1.25 & 0.25 \\
\hline $05975 \mathrm{~F}$ & bi-fuel & 23430.0 & 5 & & 1.07 & \\
\hline $05976 \mathrm{~F}$ & bi-fuel & 16807.0 & 2 & 1 & 0.59 & 0.30 \\
\hline $05992 \mathrm{~F}$ & bi-fuel & 21494.0 & & & & \\
\hline $05994 \mathrm{~F}$ & bi-fuel & 21269.0 & 1 & & 0.24 & \\
\hline $05995 \mathrm{~F}$ & bi-fuel & 20088.0 & 2 & & 0.50 & \\
\hline $05996 \mathrm{~F}$ & bi-fuel & 17379.0 & 8 & & 2.30 & \\
\hline 05997F & bi-fuel & 20552.0 & 4 & 1 & 0.97 & 0.24 \\
\hline UT & gasoline & 32317.4 & 1 & & 0.15 & \\
\hline $04353 \mathrm{G}$ & gasoline & 19379.0 & 4 & & 1.03 & \\
\hline 04354G & gasoline & 14692.0 & 2 & & 0.68 & \\
\hline $04355 \mathrm{G}$ & gasoline & 38806.0 & & & & \\
\hline
\end{tabular}




\section{Appendix E: \\ Statistics for Scheduled and Unscheduled Maintenance and Reliability}

The statistical analyses for scheduled maintenance, repairs, and reliability are discussed in the following subsections. The statistical tables should be interpreted following the discussion in Appendix $\mathrm{C}$.

\section{Scheduled Maintenance}

Table E-1 provides the summary statistics for scheduled maintenance, as divided into parts, labor, "other" (e.g., used oil disposal), and total. We constructed 95\% confidence intervals for the difference between the means for the bi-fuel vehicles in Corpus and Houston for parts, labor, and other costs. Because permanent oil filters are used in the Corpus District, Table E-1 reflects a 38\% lower parts cost but also a $132 \%$ higher labor cost for scheduled maintenance in the Corpus District than the Houston District. All of the statistical intervals comparing the means contain 0 except the labor interval; the difference in the cost of labor for scheduled maintenance is statistically different for the Corpus bi-fuel vehicles in comparison to those from the Houston District. This is due to the higher labor cost for cleaning the reusable oil filters in the Corpus Christi District.

Because all of the TxDOT vehicles perform scheduled maintenance on the suggested "harsh service" rate of, nominally, every 3 months or 3,000 miles, the scheduled maintenance costs are expected to be the same for both the bi-fuel and gasoline-only vehicles if both use the same type of oil filter. That is, because the Houston District and all 4 of the gasoline-only vehicles used replacement-type oil filters, it is expected that the costs for scheduled maintenance should be the same for the bi-fuel vehicles in the Houston District as for the gasoline-only vehicles. As expected, the mean parts costs, labor costs, other costs, and total costs are nearly identical for the bi-fuel vehicles in the Houston District as for the gasoline-only vehicles. All of the $95 \%$ confidence intervals for the differences between the means contain the value 0 . Therefore, it cannot be stated with $95 \%$ confidence that these means are statistically different. Again, this is the expected result - the costs for routine scheduled maintenance should be independent of whether it is a bi-fuel vehicle or a gasoline-only vehicle. Comparison of the gasoline controls to the bi-fuel vehicles in the Houston District yields the estimate that the mean total cost for scheduled maintenance is $\sim 0.65$ cents/mile for both gasoline-only vehicles and bi-fuel vehicles that have replacement-type oil filters. 
Table E.1. Summary Statistics for Scheduled Maintenance

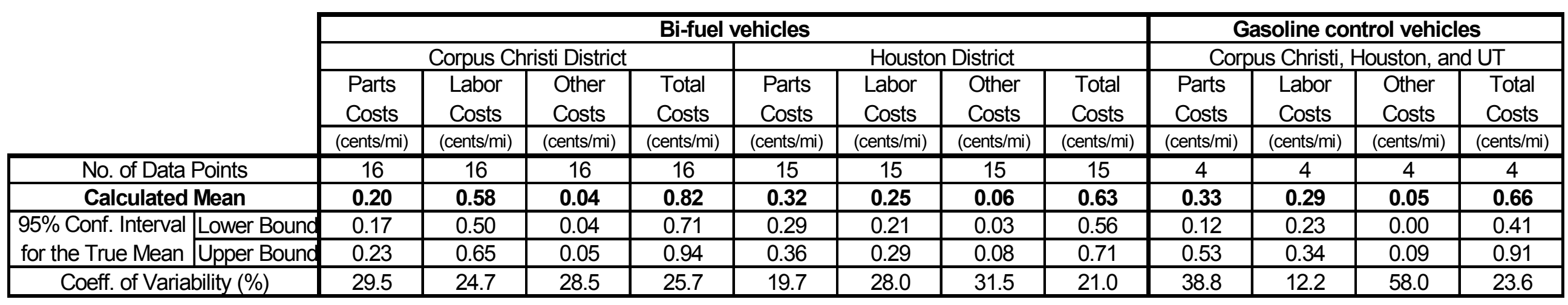




\section{Unscheduled Maintenance}

All but three of the study vehicles were under warranty throughout the project. Therefore, virtually all of the repairs were performed at no cost to TxDOT. However, TxDOT generally keeps their vehicles until well after 36,000 miles. Therefore, it was of interest to project the repair costs that might be expected after the expiration of the warranty. The method of projecting these costs was discussed in the main body of the report.

The means for the projected (post-warranty) repair costs are presented in Table E-2. Repairs do not occur on a regular schedule; many of the test vehicles had no repairs over the duration of the project whereas one had 8 repairs in less than 20,000 miles. Repairs do not follow a normal distribution (at least for this small pool of vehicles, all of which have relatively low mileage), as illustrated in Figures E-1 and E-2. Therefore, a statistical analysis based upon a normal distribution such as those presented previously is not possible. Furthermore, the very small sample size for the gasoline-only vehicles yields a large uncertainty in the validity of the mean repair cost for the gasoline-only vehicles. The sparsity of the gasoline-only data set can be addressed by examining the difference between the LPG-related maintenance and the total unscheduled maintenance for the bi-fuel vehicles; this is the portion of unscheduled maintenance that is expected to have occurred even if the vehicle had not been converted to bi-fuel operation. As shown in Figure E-1, ten of the 35 vehicles had non-LPG related repair costs in the range of 0 to 0.25 cents/mile whereas 9 of the 35, including one of the gasoline-only vehicles, had a repair cost of more than 2 cents/mile. The average non-LPG-related maintenance operating cost for the bi-fuel vehicles is 1.98 cents/mile. Because this is based upon a much larger sample size than is the mean for the 4 gasoline-only vehicles, and includes only repairs that were not related to the LPG system, it is estimated that the mean repair cost after the warranty period will be 1.98 cents/mile whether or not the vehicle has an LPG system.

It is expected that the repair costs for the bi-fuel vehicles will be higher simply because there is additional hardware on these vehicles. Figure E-2 shows that 19 of the 31 bi-fuel vehicles had an LPGrelated repair cost between 0 and 0.25 cents/mile and only 3 of the 31 had an LPG-related repair cost of more than 2 cents/mile. As shown in Table E-2, on average the additional hardware for the LPG system adds 0.77 cents/mile to the unscheduled maintenance operating cost of the bi-fuel vehicles. That is, the bi-fuel vehicles are projected to have a repair cost that is 39\% higher than that estimated for gasolineonly operation.

Although there is a large uncertainty in both the baseline repair cost (1.98 cents/mile) and the additional cost for LPG system repairs ( 0.77 cents/mile), these are the best values that can be extracted from the present data. Development of more accurate results requires observation over a longer period (more miles accumulated) and a larger pool of test vehicles, especially gasoline-only vehicles.

Table E-2. Summary Statistics for Unscheduled Maintenance

\begin{tabular}{|c|c|c|c|c|}
\hline \multicolumn{4}{|c|}{} & \multicolumn{3}{c|}{ bi-fuel vehicles } & $\begin{array}{c}\text { gasoline- } \\
\text { only } \\
\text { vehicles }\end{array}$ \\
\cline { 2 - 6 } & $\begin{array}{c}\text { Total Repair } \\
\text { Operating } \\
\text { Costs }\end{array}$ & $\begin{array}{c}\text { LPG } \\
\text { Related } \\
\text { Operating } \\
\text { Costs }\end{array}$ & $\begin{array}{c}\text { Non-LPG } \\
\text { Related } \\
\text { Operating } \\
\text { Costs }\end{array}$ & $\begin{array}{c}\text { Total Repair } \\
\text { Operating } \\
\text { Costs }\end{array}$ \\
\cline { 2 - 6 } & (cents/mile) & (cents/mile) & (cents/mile) & (cents/mile) \\
\hline No. of Data Points & 31 & 31 & 31 & 4 \\
\hline Mean & $\mathbf{2 . 7 4}$ & $\mathbf{0 . 7 7}$ & $\mathbf{1 . 9 8}$ & $\mathbf{0 . 6 8}$ \\
\hline
\end{tabular}




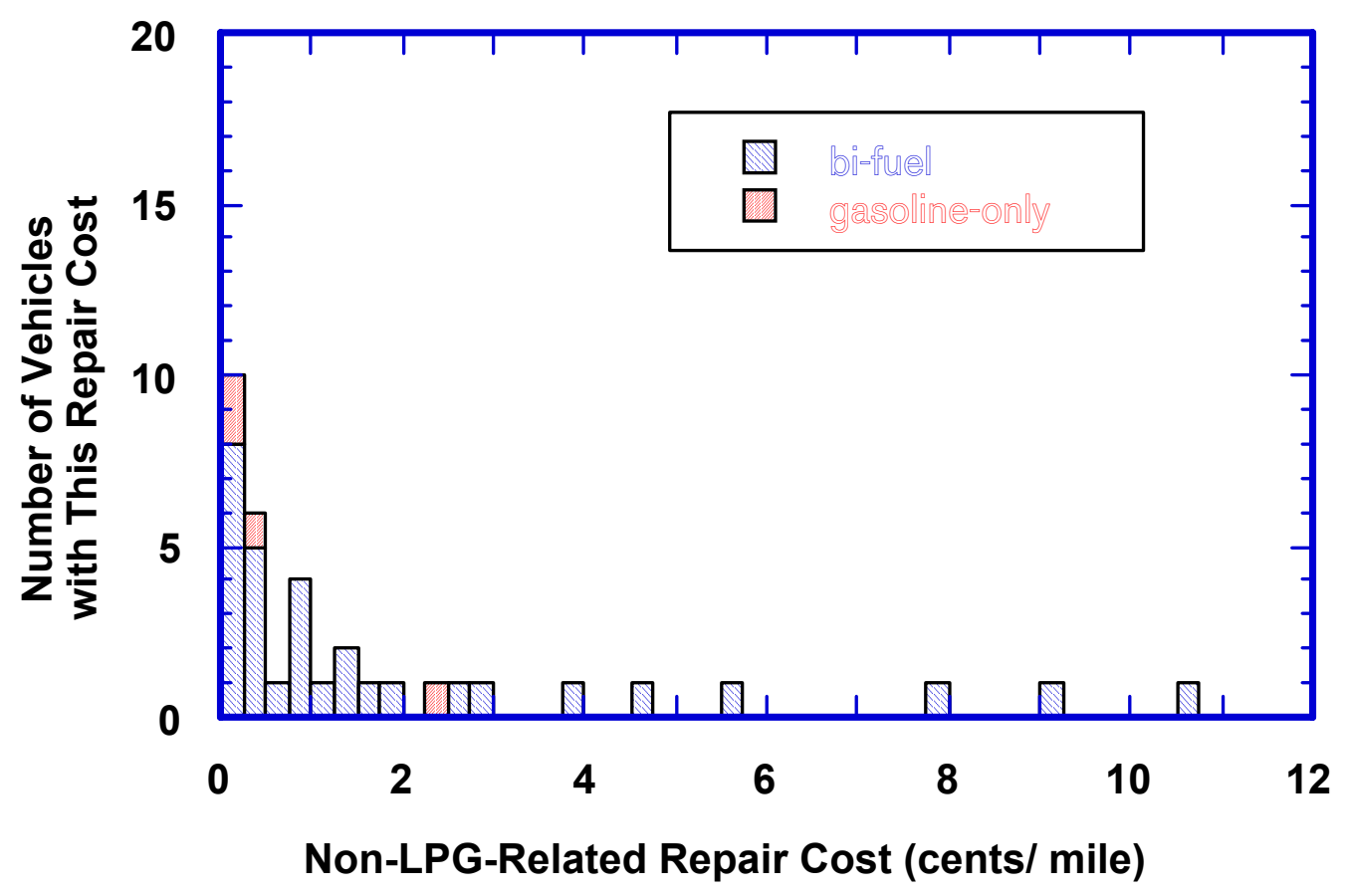

Figure E-1. Distribution of non-LPG related repair costs for the 35 project vehicles

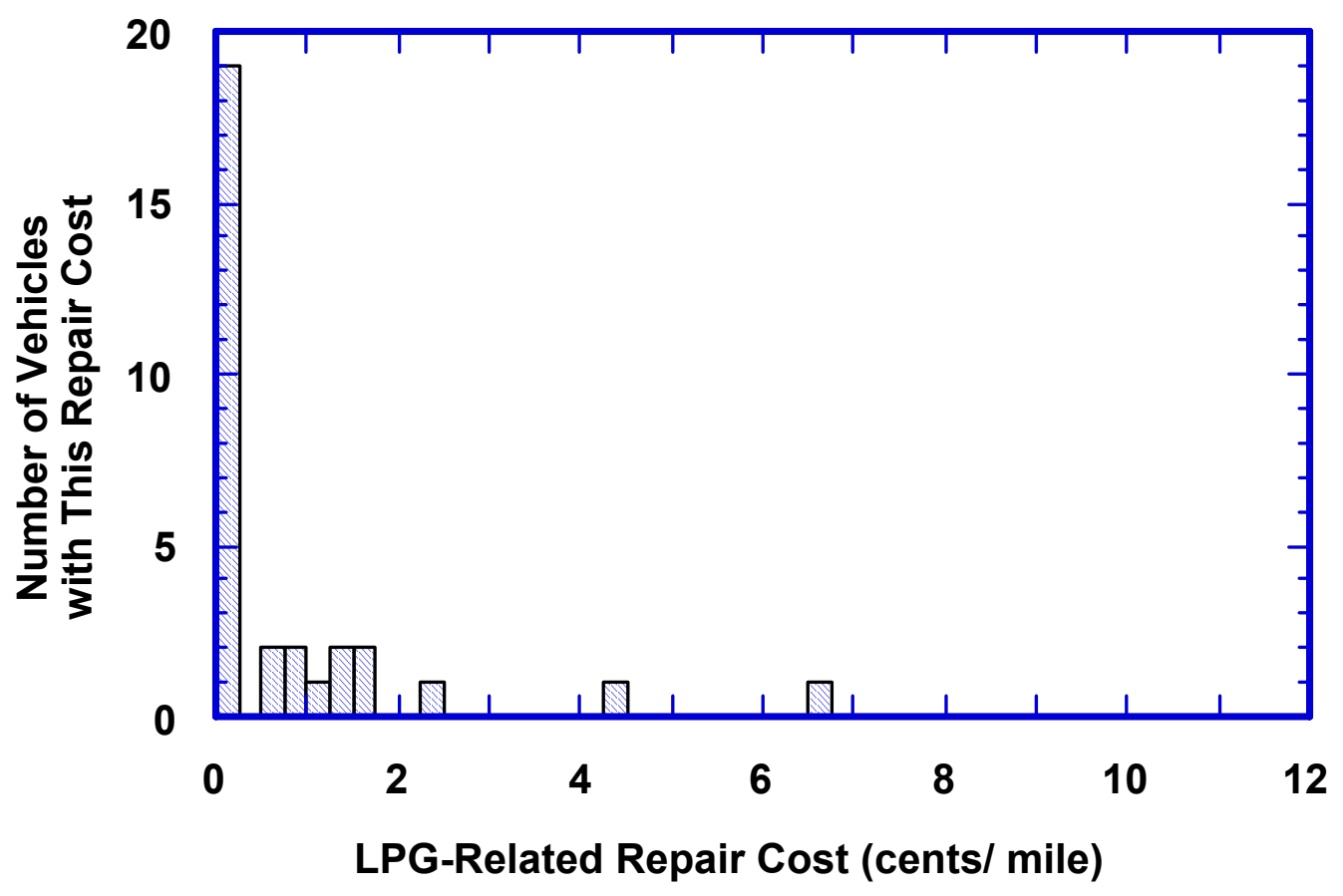

Figure E-2. Distribution of the LPG related repair costs for the 31 bi-fuel vehicles 


\section{Reliability}

We used the number of unscheduled maintenance occurrences per five thousand miles to evaluate the reliability of the vehicles being studied. The statistical summary is provided in Table E-3. The corresponding data are available in Appendix D.

As was also true for the repair costs, the fact that repairs do not follow a normal distribution means that the statistics that are based upon a normal distribution are not presented in Table E-3. As was done for the repair costs above, the sparsity of the gasoline-only data set was addressed by examining the difference between the LPG-related repair rate and the total repair rate for the bi-fuel vehicles; this is the portion of the repairs that is expected to have occurred even if the vehicle had not been converted to bifuel operation. As shown in Figure E-4, six of the 35 test vehicles had a non-LPG-related repair rate between 0 and 0.1 repairs per 5,000 miles whereas 8, including one of the gasoline-only vehicles, had repair rates of more than 1 repair per 5,000 miles. On average, the non-LPG-related repair rate for the bi-fuel vehicles is 0.65 repairs per 5,000 miles. Because this is based upon a much larger sample size than is the mean repair rate for the 4 gasoline-only vehicles, and includes only repairs that were not related to the LPG system, it is estimated that the mean repair rate would be 0.65 repairs per 5,000 miles whether or not the vehicle has an LPG system.

Figure E-4 shows that 18 of the 31 bi-fuel vehicles had an LPG-related repair rate between 0 and 0.1 repairs per 5,000 miles and none had an LPG-related repair rate of more than 1 per 5,000 miles. As also shown in Table E-3, on average the LPG system adds about 0.11 repairs per 5,000 miles to the baseline repair rate. The present finding of 1.1 repairs every 50,000 miles agrees surprisingly well with that from a previous study (Dardalis et al., 1998), which found 1.25 repairs every 50,000 miles, in spite of the small sample sizes in both studies.

As was also true for the repair costs, the estimated means for both the baseline repair rate $(0.65$ repairs/5000 miles) and the $\sim 15 \%$ higher repair rate due to the LPG system ( 0.11 repairs/5000 miles) have a significant uncertainty but are the best values that can be extracted from the present data. Development of more accurate results requires observation over a longer period (more miles accumulated) and a larger pool of test vehicles, especially gasoline-only vehicles.

Table E-3. Summary of the Statistics for Reliability

\begin{tabular}{|c|c|c|c|c|}
\hline \multicolumn{4}{|c|}{} & \multicolumn{3}{|c|}{ bi-fuel vehicles } & $\begin{array}{c}\text { gasoline- } \\
\text { only } \\
\text { vehicles }\end{array}$ \\
\cline { 2 - 6 } & $\begin{array}{c}\text { overall } \\
\text { repairs }\end{array}$ & $\begin{array}{c}\text { LPG related } \\
\text { repairs }\end{array}$ & $\begin{array}{c}\text { non-LPG } \\
\text { related } \\
\text { repairs }\end{array}$ & $\begin{array}{c}\text { overall } \\
\text { repairs }\end{array}$ \\
\cline { 2 - 6 } & $\begin{array}{c}\text { (repairs/5000 } \\
\text { miles) }\end{array}$ & $\begin{array}{c}\text { (repairs/5000 } \\
\text { miles) }\end{array}$ & $\begin{array}{c}\text { (repairs/5000 } \\
\text { miles) }\end{array}$ & $\begin{array}{c}\text { (repairs/5000 } \\
\text { miles) }\end{array}$ \\
\hline No. of Data Points & 31 & 31 & 31 & 4 \\
\hline Mean & $\mathbf{0 . 7 6}$ & $\mathbf{0 . 1 1}$ & $\mathbf{0 . 6 5}$ & $\mathbf{0 . 4 7}$ \\
\hline
\end{tabular}




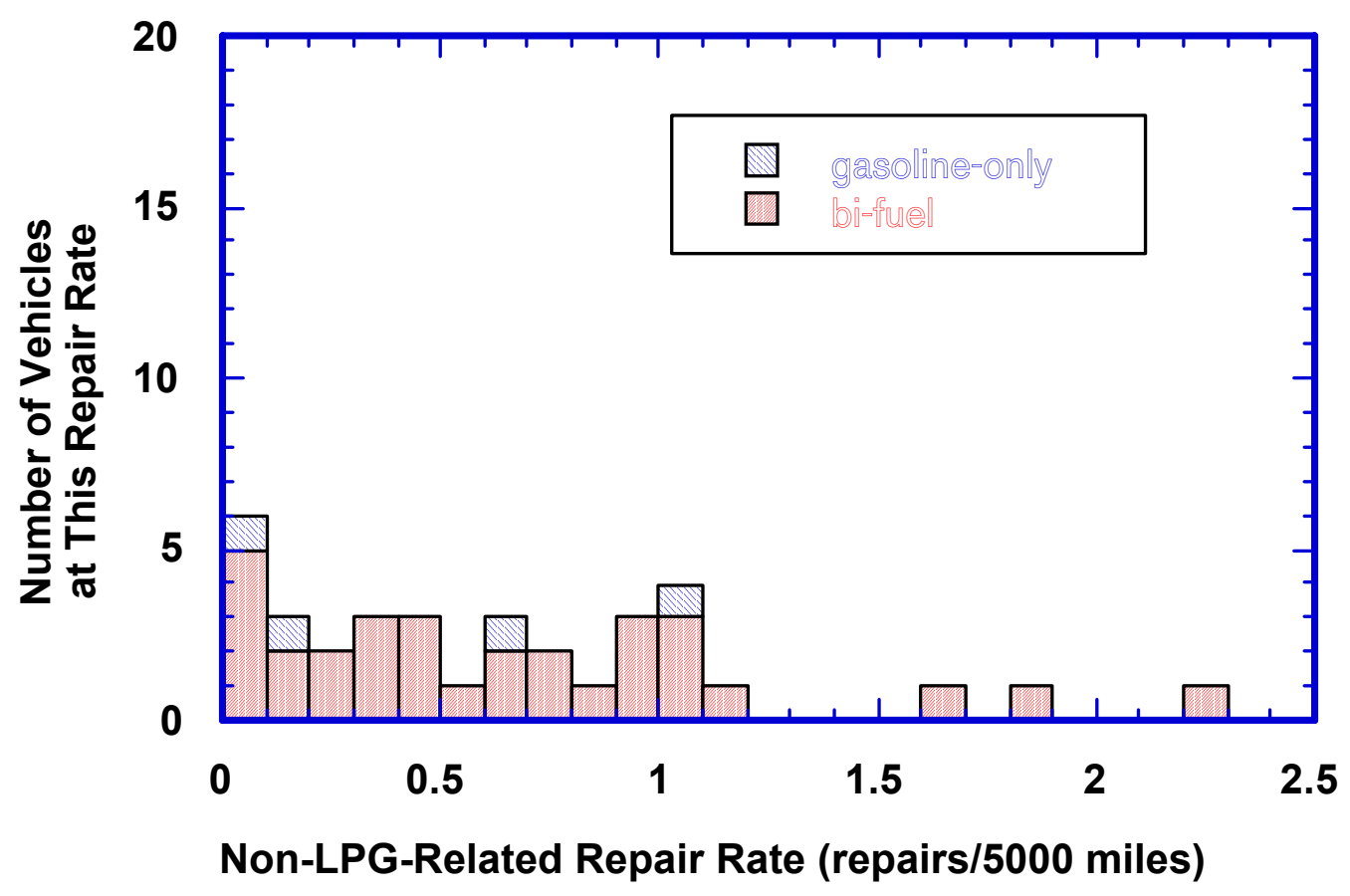

Figure E-3. Distribution of non-LPG related repair rates for the 35 project vehicles

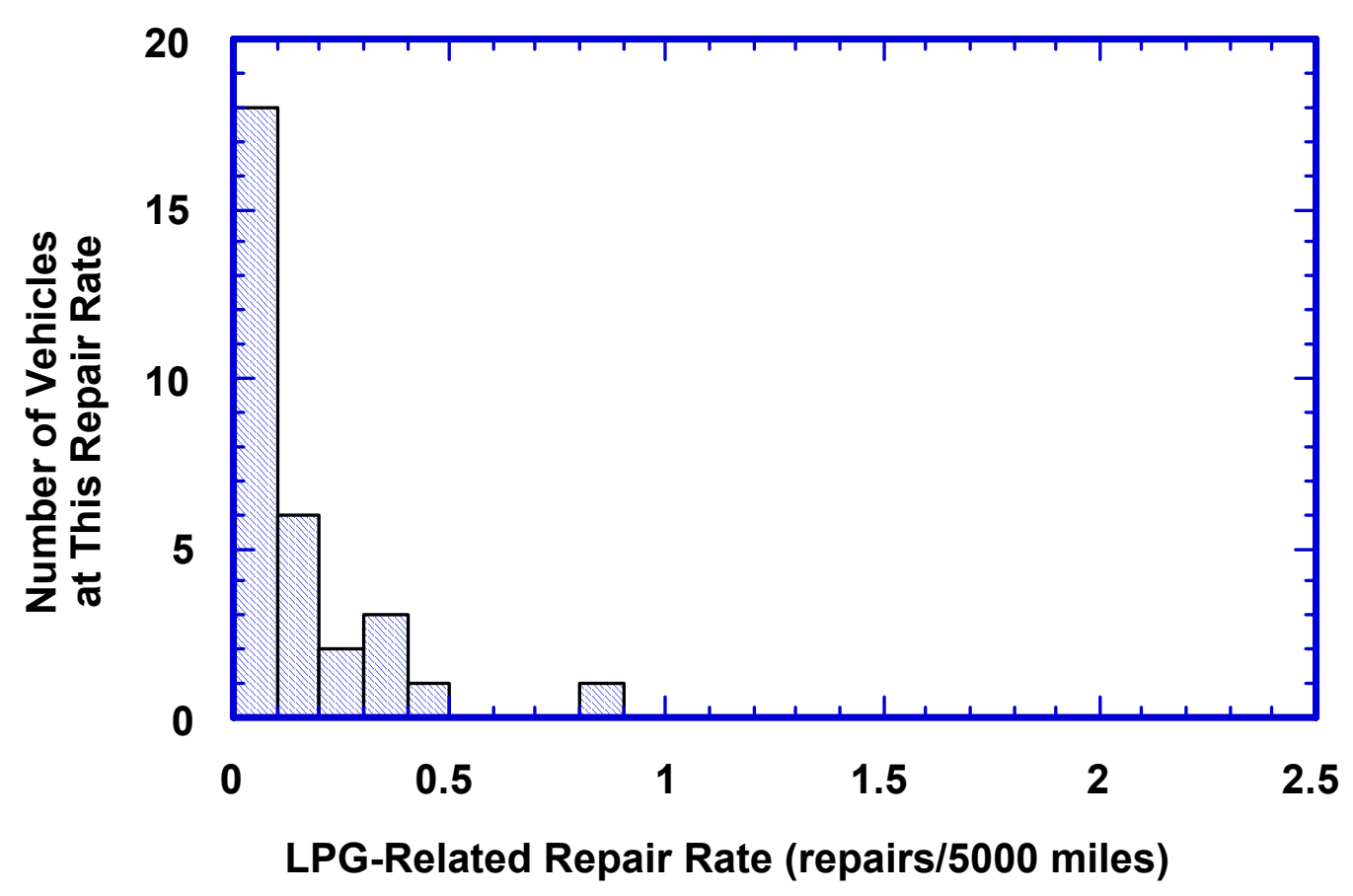

Figure E-4. Distribution of LPG related repair rates for the 31 bi-fuel vehicles 


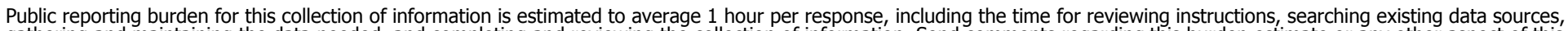

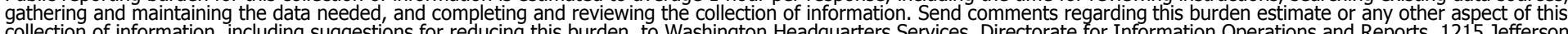

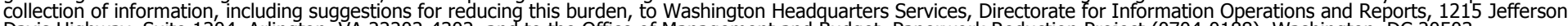

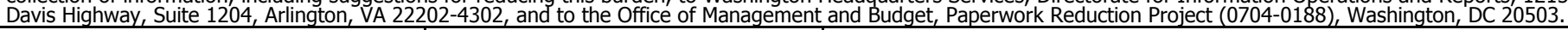
1. AGENCY USE ONLY (Leave blank)
2. REPORT DATE
3. REPORT TYPE AND DATES COVERED May 1999 Final Report

4. TITLE AND SUBTITLE

Texas Bi-Fuel Liquefied Petroleum Gas Pickup Study: Final Report

5. FUNDING NUMBERS

FU905010

6. AUTHOR(S)

Y. Huang, R.D. Matthews, and E.T. Popova

7. PERFORMING ORGANIZATION NAME(S) AND ADDRESS(ES)

Department of Mechanical Engineering

8. PERFORMING ORGANIZATION

University of Texas at Austin

Austin, Texas 78712

9. SPONSORING/MONITORING AGENCY NAME(S) AND ADDRESS(ES)

National Renewable Energy Laboratory

1617 Cole Blvd.

Golden, CO 80401-3393
10. SPONSORING/MONITORING AGENCY REPORT NUMBER

NREL/SR-540-26003

\section{SUPPLEMENTARY NOTES}

NREL Technical Monitor: P. Whalen

12a. DISTRIBUTION/AVAILABILITY STATEMENT National Technical Information Service U.S. Department of Commerce 5285 Port Royal Road

Springfield, VA 22161 12b. DISTRIBUTION CODE 1504

13. ABSTRACT (Maximum 200 words)

Alternative fuels may be an effective means for decreasing America's dependence on imported oil; creating new jobs; and reducing emissions of greenhouse gases, exhaust toxics, and ozone-forming hydrocarbons. However, data regarding in-use fuel economy and maintenance characteristics of alternative fuel vehicles (AFVs) have been limited in availability. This study was undertaken to compare the operating and maintenance characteristics of bi-fuel vehicles (which use liquefied petroleum gas, or propane, as the primary fuel) to those of nominally identical gasoline vehicles. In Texas, liquefied petroleum gas is one of the most widely used alternative fuels. The largest fleet in Texas, operated by the Texas Department of Transportation (TxDOT), has hundred of bi-fuel (LPG and gasoline) vehicles operating in normal daily service. The project was conducted over a 2 -year period, including 18 months (April 1997-September 1998) of data collection on operations, maintenance, and fuel consumption of the vehicles under study. This report summarizes the project and its results.

14. SUBJECT TERMS

Alternative fuels, liquefied petroleum gas, LPG, vehicle operation and maintenance

17. SECURITY CLASSIFICATION OF REPORT
18. SECURITY CLASSIFICATION OF THIS PAGE
19. SECURITY CLASSIFICATION OF ABSTRACT
15. NUMBER OF PAGES 81

16. PRICE CODE

20. LIMITATION OF ABSTRACT

Standard Form 298 (Rev. 2-89) Prescribed by ANSI Std. Z39-18

NSN 7540-01-280-5500 